No 4077

Studia nad Autorytaryzmem i Totalitaryzmem 43, nr 3

Wrocław 2021

https://doi.org/10.19195/2300-7249.43.3.31

TOMASZ KRUSZEWSKI

ORCID: 0000-0003-3202-2805

Uniwersytet Wrocławski

tomasz.kruszewski@uwr.edu.pl

\title{
Prawo osobowe na ziemiach polskich wcielonych do Rzeszy Niemieckiej podczas drugiej wojny światowej
}

Slowa kluczowe: Bürgerliches Gesetzbuch z 1896 roku, prawa podmiotowe prywatne jednostek, prawa osobistości (Persönlichkeitsrechtes), nierówność wobec prawa, rasizm, prawo rasowe (Rassenrecht), „obcy rasowo”, eugenika, eutanazja, pozycja prawna obywateli polskich pod niemieckim prawem okupacyjnym.

\author{
PERSONAL LAW ON POLISH TERRITORY INCORPORATED \\ TO THE GERMAN REICH DURING THE SECOND WORLD WAR
}

\begin{abstract}
The subject of this article are basic questions within the range of civil law. They concern the general position of a human and legal people in the sphere of this law on Polish territory, which was incorporated into the Third Reich. The position of individuals, the citizens of II RP, under the occupation of the Third Reich in years 1939-1945, is analysed by the author not from the perspective of literal meaning of regulations of general part of Bürgerliches Gesetzbuch (BGB) from 1896, but from the perspective of their specific interpretation, congruent with strategic and ideological purposes of the Nazi regime.

In the article, the following issues are touched upon in turn: 1) personal law in terms of classical civil law contra national-socialist regime; 2) racism towards civil rights of a subjective individual; 3) elimination of the Jews from the legal relationships of civil law; 4) difficulties in the sphere of access to certain professions for Polish people and some restrictions upon personal rights; 5) the dependence of possibilities of exercising the private personal right on the consent to denationalization; 6) ban concerning getting married and the right to motherhood and fatherhood; 7) legislation of sterilisation and euthanasia.

The formal changes in the legislation which were in force in the Third Reich - except for personal and family law (as well as legal rules connected with it regarding health protection of off-
\end{abstract}


spring), and "peasant law" (Bauernrecht) — were not significant, as is proved by the author. The old legal order was reversed in the Third Reich due to its new interpretation: classical concepts and legal institutions were filled with a different content.

After the formal extension of BGB to territories incorporated into the Reich, which followed the decree of 25 September 1941 introducing German civil law, these territories became a field of social-political and racial-nationalist experiments, which in fact had a little in common with the German Civil Code's regulations. A principle of equal access to private subjective rights was respected only in case of German people, i.a. the part which passively gave up to indoctrination. In relation to Jews, racism spoiled in this case the idea and concept of private subjective rights.

Keywords: Bürgerliches Gesetzbuch from 1896, private personal rights of individuals, personal rights (Persönlichkeitsrechtes), inequality in law, racism, racial law (Rassenrecht), 'foreign racially', eugenics, euthanasia, legal position of polish citizens under German occupation law.

\section{Prawo osobowe klasycznej cywilistyki a reżim narodowosocjalistyczny}

Przedmiotem niniejszych rozważań są podstawowe kwestie z zakresu prawa cywilnego, dotyczące ogólnej pozycji człowieka i osób prawnych w sferze tego prawa na polskich ziemiach wcielonych do Trzeciej Rzeszy. Oczywiście uwzględnić należy przy tym fakt, że status prawny Polaka w różnych regionach pod władzą hitlerowską wykazywał pewne zróżnicowanie ${ }^{1}$, jednak ludność żydowską traktowano wszędzie zgodnie z tymi samymi dyrektywami, które wynikały z założeń rasizmu i antysemityzmu.

Trzecia Rzesza w fasadowej postaci zachowała podstawowy zakres obowiązywania dotychczasowych przepisów pochodzących sprzed „narodowosocjalistycznej rewolucji” (Machtübernahme). Dotyczyło to również prawa cywilnego, a zwłaszcza niemieckiego kodeksu cywilnego - Bürgerliches Gesetzbuch z 1896 roku (BGB) ${ }^{2}$. Nawet jeśli odrzucimy dosyć radykalny pogląd, że prawo cywilne z okresu Republiki Weimarskiej obowiązywało nadal w Trzeciej Rzeszy, że uznawano jego moc i stosowano je w praktyce ${ }^{3}$, to przecież trudno zaprzeczyć, iż formalne zmiany - $\mathrm{z}$ wyjątkiem sfery prawa osobowego, $w$ tym familijnego

1 Stanisław Salmonowicz stwierdza: „Spróbujmy wskazać na niektóre elementy statusu prawnego Polaka w różnych regionach pod władzą niemiecką. Realna sytuacja Polaka, obciążonego różnymi zarządzeniami władz niemieckich, była [...] zróżnicowana i dziś nie daje się nieraz w pełni sprecyzować. Różniła się także z punktu widzenia większych bądź mniejszych możliwości »obchodzenia«, a więc niestosowania się do wielu rozporządzeń”, idem, Status prawny Polaka pod okupacja niemiecka (1939-1945). Uwagi o potrzebie badań, „Krakowskie Studia z Historii Państwa i Prawa" 9, 2016, nr 3, s. 354.

2 Wyd. polskie: Kodeks cywilny obowiązujacy na Ziemiach Zachodnich Rzeczypospolitej Polskiej, oprac. Z. Lisowski, Poznań 1933.

${ }^{3}$ H. Hattenhauer, Grundbegriffe des Bürgerlichen Rechts. Historisch-dogmatische Einführung, München 1982, s. 14; zob. też późniejsze wydania. 
i powiązanych z nim przepisów o ochronie zdrowia potomstwa, ponadto zaś ,prawa chłopskiego" (Bauernrecht) - nie były aż tak znaczne ${ }^{4}$.

Nie kryteria formalne, a w szczególności nie sam układ BGB, powinny tym samym wyznaczać perspektywę obserwacji badawczej. Skupienie się na części ogólnej BGB, który w swej systematyce zewnętrznej odchodził od klasycznego podziału: personae, res, actiones, nie umożliwia uchwycenia charakterystycznych rysów prawa okresu Trzeciej Rzeszy. Miarodajnym wyznacznikiem jest natomiast ogólna pozycja człowieka i osób prawnych w sferze prawa cywilnego, co też w całej rozciągłości ma zastosowanie do sytuacji dotychczasowych obywateli II RP pod okupacją w latach 1939-1945. Sam hitlerowski reżim zamierzał zresztą odejść od abstrakcji prawnej, tak znamiennie odzwierciedlającej się w idei części ogólnej kodeksu cywilnego. BGB miał zastąpić Volksgesetzbuch, który powracał do idei prawa osobowego ${ }^{5}$.

Na pozycję jednostki należy przy tym spojrzeć nie w perspektywie literalnego brzmienia przepisów części ogólnej BGB, lecz ich specyficznej interpretacji, zgodnej z celami strategicznymi i ideologicznymi reżimu. Stary porządek prawny odwracano w Trzeciej Rzeszy przez jego nową interpretację, klasyczne pojęcia oraz instytucje prawne wypełniano inną treścią.

Zwraca uwagę to, że prawo sprzed narodowosocjalistycznej Machtübernahme co prawda nadal obowiązywało, ale nie dotyczyło osób wykluczonych ze wspólnoty narodowej jak komuniści, pozbawieni praw politycznych, czy Żydzi, pozbawieni niemal wszelkich praw. W związku z tym zmieniła się określona w części ogólnej BGB treść pojęcia zdolności prawnej i zdolności do czynności prawnych, co specyficznego jeszcze charakteru nabrało w prawie małżeńskim Trzeciej Rzeszy.

Należy uwzględnić przede wszystkim to, że powszechne prawo osobiste $\mathrm{w}$ postaci prawa podmiotowego o charakterze bezwzględnym, skutecznego erga omnes, które odzwierciedlało światopogląd indywidualistyczny, było konstrukcją diametralnie przeciwstawną do panującej w Trzeciej Rzeszy idei praw przysługujących wspólnocie narodowej ${ }^{6}$. Po drugie zaś, charakterystyczny dla

${ }^{4}$ W nauce polskiej taki pogląd wyrazili już prawnicy II RP; zob. L. Górnicki, Prawo Trzeciej Rzeszy w nauce i publicystyce prawniczej Polski międzywojennej (1933-1939), Bielsko-Biała 1993, s. 165 n.; por. K. Jonca, Koncepcje narodowosocjalistycznego prawa w Trzeciej Rzeszy, SnFiZH 3, 1977, s. 69. Jak stwierdza M. Zmierczak, podobne zapatrywania znajdujemy w większości prac naukowych dotyczących prawa Trzeciej Rzeszy; eadem, Refleksje o prawie cywilnym $w$ totalitarnym ustroju III Rzeszy, [w:] Księga jubileuszowa Profesora Tadeusza Smyczyńskiego, red. M. Andrzejewski et al., Torun 2008, s. 852.

5 Systematyka zbioru: prawo osobowe, prawo rodzinne, prawo spadkowe, prawo umów, prawo własności, prawo pracy, prawo przedsiębiorstwa i prawo spółek. Pod koniec 1942 r. został opublikowany projekt księgi I Der Volksgenosse, na którego czele postawiono 25 podstawowych praw, po części bardzo bliskich programowi NSDAP z 1923 r. Prace przerwano w 1944 r.; więcej Volksgesetzbuch. Teilentwürfe, Arbeitsberichte und sonstige Materialien, red. W. Schubert, Berlin 1988.

${ }^{6}$ Więcej L. Górnicki, T. Kruszewski, Zasadnicze przejawy ingerencji w prawa podmiotowe prywatne jednostek przez Trzecia Rzesze, ,Studia nad Autorytaryzmem i Totalitaryzmem” 2017, nr 1, s. 47. 
Trzeciej Rzeszy prymat polityki nad prawem pociąga za sobą to, że właściwą perspektywą obserwacji w odniesieniu do obywateli II RP w okresie okupacji hitlerowskiej muszą być nie tylko przepisy prawa cywilnego obowiązujące na ziemiach wcielonych do Rzeszy, ale polityka eksterminacji narodu, ludobójstwa, stosowania tortur, prześladowań, wyniszczania, poniżania czy zbrodniczych eksperymentów medycznych ${ }^{7}$, stanowiących dla tych, którzy je przeżyli, podstawę do roszczeń cywilnoprawnych ${ }^{8}$. Przepisy części ogólnej, ustawodawstwo z zakresu osobowego prawa małżeńskiego, należy więc postrzegać przez pryzmat tejże polityki.

7 Zob. C. Pilichowski, Plan i skutki polityki Trzeciej Rzeszy wobec Polski w okresie II wojny światowej, „Studia nad Faszyzmem i Zbrodniami Hitlerowskimi” (SnFiZH) 3, 1977; idem, Badanie i ściganie zbrodni hitlerowskich 1944-1974, Warszawa 1975; idem, Zbrodnie i sprawcy. Ludobójstwo hitlerowskie przed sądem ludzkości i historii, Warszawa 1980; K. Jonca, Naród polski w koncepcjach politycznych okupanta hitlerowskiego (1939-1945), [w:] Studia z dziejów myśli politycznej w Niemczech w XIX i XX wieku, red. H. Olszewski, Poznań 1982, s. 267-282 i tam podana literatura; M. Olszewski, Straty i martyrologia ludności polskiej w Poznaniu 1939-1945, Poznań 1973; J. Heydecker, J. Leeb, Trzecia Rzesza w świetle Norymbergii. Bilans tysiaca lat, Warszawa 1979; Eksterminacja Żydów na ziemiach polskich w okresie okupacji hitlerowskiej. Zbiór dokumentów, oprac. T. Berenstein, A. Eisenbach, A. Rutkowski, Warszawa 1957; A. Eisenbach, Hitlerowska polityka zagłady Żydów, Warszawa 1961; Akcja Reinhardt. Zagłada Żydów w Generalnym Gubernatorstwie, red. D. Libionka, Warszawa 2004; M.R. Marrus, Holocaust, Warszawa 1993; F. Katzmann, Rozwiazanie kwestii zydowskiej w dystrykcie Galicja, oprac. A. Żbikowski, Warszawa 2001; M. Gilbert, Atlas historii Holocaustu, Liszki 2001; idem, Holocaust. Ludzie. Dokumenty. Pamięć, Warszawa 2002; R. Hilberg, Sprawcy, ofiary, świadkowie. Zagłada Żydów 1933-1945, Warszawa 2007; F. Katzmann, Rozwiazanie kwestii żydowskiej w dystrykcie Galicja, Warszawa 2009; T. Musioł, Dachau 1933-1945, Katowice 1968; J. Gielo, Gross Rosen, Warszawa 1970; K. Dunin-Wąsowicz, Obóz koncentracyjny Stutthof, Gdynia 1966; Stutthof. Hitlerowski obóz koncentracyjny, Warszawa 1988; S. Dobosiewicz, Mauthausen-Gusen Obóz zagłady, Warszawa 1977; T. Cieślak, Oranienburg-Sachsenhausen. Hitlerowskie obozy koncentracyjne w latach 1933-1945, Warszawa 1972; Oświęcim. Hitlerowski obóz masowej zagłady, red. W. Michalak, Warszawa 1981; D. Schenk, Albert Forster - gdański namiestnik Hitlera. Zbrodnie hitlerowskie w Gdańsku i Prusach Zachodnich, Gdańsk 2002; C. Epstein, Wzorcowy nazista. Arthur Greiser i okupacja Kraju Warty, przeł. J. Włodarczyk, Wrocław 2011; E. Klee, Auschwitz. Medycyna III Rzeszy i jej ofiary, Kraków 2005; S. Sterkowicz, Nieludzka medycyna. Lekarze w stużbie nazizmu, Warszawa 2007; L. Reese, Auschwitz. Naziści i „ostateczne rozwiąanie”, przeł. P. Stachura, Warszawa 2005; idem, Holokaust. Nowa historia, przeł. Ł. Praski, Warszawa 2018; M. Grzywacz, Pole eksperymentalne Warthegau. Glossy do pewnych wypowiedzi Edyty Stein, „ZNCB im. Edyty Stein. Fenomen Edyty Stein — Das Phänomen Edith Stein" 2014, nr 11, s. 185-197.

${ }^{8}$ Kwestię roszczeń cywilnoprawnych ofiar nazizmu w odniesieniu do szkód na osobie i majątku (także robotników przymusowych) regulowało powojenne ustawodawstwo poszczególnych stref okupacyjnych i ustawodawstwo związkowe niemieckie. Rozwój i koncepcje niemieckiego prawa indemnizacyjnego z RFN analizuje Cornelius Pawlita, Geschichte der Entschädigung in der Bundesrepublik Deutschland, [w:] Zwangsarbeit im Nationalsozialismus und die Rolle der Justiz. Täterschaft, Nachkriegsprozesse und die Auseinandersetzung um Entschädigungsleistungen, red. H. Kramer, K. Uhl, J.-Ch. Wagner, Nordhausen 2007, s. 68-85; obszernie o tym też w publikacji Entschädigung von NS-Unrecht Regelungen zur Wiedergutmachung, Bundesministeriums der Finanzen, August 2011. 
Po formalnym rozciągnięciu BGB na ziemie wcielone do Rzeszy, co nastąpiło rozporządzeniem z 25 września 1941 roku wprowadzającym niemieckie prawo cywilne, stanowiły one tym samym pole do eksperymentów społeczno-politycznych i rasowo-nacjonalistycznych, niewiele mających wspólnego z przepisami kodeksu9 ${ }^{9}$ Szczególne znaczenie ma tu segregacja rasowa, zmierzająca do eliminowania ludności „niearyjskiej”, ale działania władz Trzeciej Rzeszy na ziemiach wcielonych zmierzały przecież także do unicestwienia narodowości polskiej i umocnienia żywiołu niemieckiego, w tym przez pozbawienie własności dotychczasowych obywateli polskich polskiego i żydowskiego pochodzenia ${ }^{10}$.

Zasada równego dostępu do praw podmiotowych prywatnych była przestrzegana tylko w odniesieniu do ludności niemieckiej, i tylko tej jej części, która biernie poddawała się indoktrynacji. Reszta ludności miała być zamieniona w ,niewolników”, jak mawiał Adolf Hitler na konferencjach z przywódcami partii narodowosocjalistycznej. Nader znamiennie ujął to szef kancelarii NSDAP, zastępca i osobisty sekretarz Hitlera Martin Bormann:

Obowiązkiem Słowian jest pracować dla nas. Z chwilą, kiedy ich nie potrzebujemy, mogą umrzeć. Dlatego przymusowe szczepienia i niemiecka służba zdrowia są zbędne. Płodność Słowian jest niepożądana. Niech używają prezerwatyw albo robią skrobanki, im więcej — tym lepiej. Oświata jest niebezpieczna. Wystarczy, jeśli potrafią zliczyć do stu. [...] My jesteśmy panami, my mamy pierwszeństwo ${ }^{11}$.

\section{Rasizm wobec cywilnych praw podmiotowych}

Kryteria rasistowskie odnoszono także do obywateli polskich na ziemiach polskich wcielonych do Rzeszy, co było kontynuacją polityki stosowanej wobec mniejszości polskiej w Niemczech hitlerowskich jeszcze przed wybuchem drugiej wojny światowej. Jaskrawym tego przykładem była ustawa o zagrodach

9 RGB1. I, Jg. 1941, s. 597, Veordnung über die bürgerliche Rechtspflege in den eingegliederten Ostgebieten (Ost-Rechtspflege-Verordnung-ORpflVO-). Vom. 25. September 1941; RGBl. I, Jg. 1941, s. 599, Erste Durchsführungsverordnung zur Veordnung über die bürgerliche Rechtspflege in den eingegliederten Ostgebieten (Ost-Rechtspflege-Verordnung-ORpflVO-). Vom. 25. September 1941.

10 M. Sikora, Zasady i praktyka przejęcia majątku polskiego przez III Rzeszę, ze szczególnym uwzględnieniem sektora rolnego oraz mieszkaniowego, na przyktadzie prowincji ślaskiej (górnoślaskiej) w latach 1939-1944, „Pamięć i Sprawiedliwość” 2008, nr 2 (13), s. 43-81; cz. 2, „Pamięć i Sprawiedliwość” 2009, nr 1 (14), s. 177-199; D. Majer, ,, Narodowo obcy” w III Rzeszy. Przyczynek do narodowosocjalistycznego ustawodawstwa i praktyki prawniczej $w$ administracji $i$ wymiarze sprawiedliwości ze szczególnym uwzględnieniem ziem wcielonych do Rzeszy i Generalnego Gubernatorstwa, Warszawa 1989, s. 123 n.

11 Cyt. za: J. Heydecker, J. Leeb, op. cit., s. 391. 
dziedzicznych z 29 września 1933 roku ${ }^{12}$, która dotknęła ludność polską w Trzeciej Rzeszy. Uzależniała ona zdolność do czynności prawnych w zakresie objęcia gospodarstwa (Bauernfähigkeit) od przesłanek rasowych, to jest „krwi niemieckiej lub pokrewnej”"13 oraz od „zdolności do działań gospodarczych” (Wirtschaftsfähigkeit) i od „zdolności bycia człowiekiem honorowym” (Ehrbarkeit), które to właściwości osobiste musiały zachodzić łącznie.

Fundamentalne w ideologii Trzeciej Rzeszy ustawy norymberskie, to jest ustawa o obywatelstwie oraz ustawa o ochronie niemieckiej krwi i niemieckiej czci, uchwalone na „zjeździe wolności” w Norymberdze 15 września 1935 roku $^{14}$, zostały rozciągnięte na ziemie polskie wcielone do Rzeszy. Miało to daleko idące skutki, gdyż o ile podstawą BGB była klasyczna idea równości praw przysługujących każdemu człowiekowi z chwilą urodzenia (§ 1), z zastrzeżeniem dotyczącym możliwych ograniczeń zdolności do czynności prawnych, o tyle ustawy norymberskie wyrażały bezwzględną ideę nierówności wobec prawa ${ }^{15}$.

Rozporządzenie z 31 maja 1941 roku wprowadzało formalnie na ziemie wcielone ustawę o obywatelstwie Rzeszy z 15 września 1935 roku oraz pierwsze

12 RGB1. I, Jg. 1933, s. 685, Reichserbhofgesetz. Vom 29. September 1933 oraz pruska ustawa z 15 maja 1933 r. w Preussische Gesetzsammlung, s. 165, Bäuerlisches Erbhofrecht. Vom 15. Mai 1933.

$13 \S 3$ ustawy stanowił, że krwi niemieckiej lub równorzędnej (stammesgleichen Blutes) nie był ten, kto miał wśród przodków ze strony zarówno ojca, jak i matki, począwszy od 1 stycznia 1800 r., przodków krwi żydowskiej lub kolorowej (jüdisches oder farbigen Blutes). Pruska ustawa z 15 maja 1933 r. przewidywała w $\S 2$ ust. 1 nabywanie zagród dziedzicznych tylko przez osoby „krwi niemieckiej lub podobnej do niemieckiej”, a § 2 ust. 2 wykluczał osoby „kolorowe” i Żydów.

14 RGB1. I, Jg. 1935, s. 1146, Reichsbürgergesetz. Vom 15. September 1935; RGB1. I, Jg. 1935, s. 1146, Gesetz zum Schutze des deutschen Blutes und der deutschen Ehre. Vom 15. September 1935 - przekładu ustawy o obywatelstwie na język polski dokonał M. Berżyński (Ustawa o obywatelstwie Rzeszy wobec mniejszości narodowych w Niemczech, „Sprawy Narodowościowe” 1935, nr 5, s. 490-491), który przełożył też pierwsze rozporządzenie wykonawcze do ustawy o obywatelstwie z 14 listopada 1935 r. (RGB1. I, Jg. 1935, s. 1333, Erste Verordnung zum Reichsbürgergesetz. Vom 14. November 1935) zamieszczoną w tym samym opracowaniu (ibidem, s. 493), lecz także — publikowaną poza tym artykułem - ustawę o ochronie niemieckiej krwi i niemieckiej czci („Sprawy Narodowościowe" 1935, nr 5, s. 500) oraz pierwsze rozporządzenie wykonawcze do ustawy o ochronie niemieckiej krwi i niemieckiej czci z 14 listopada 1935 r. (RGBl. I, Jg. 1935, s. 1333, Erste Verordnung zum Reichsbürgergesetz. Vom 14. November 1935 („Sprawy Narodowościowe” 1935, nr 5, s. 500-502). Rozporządzenie to przełożył też F. Celnikier, Pojęcie Żyda w doktrynie i hitlerowskim prawodawstwie, SnFiZH 9, 1985, s. 225. Piąte rozporządzenie wykonawcze do ustawy o obywatelstwie Rzeszy z 27 września 1938 r. (RGBl. I, Jg. 1938, s. 1403, Fünfte Verordnung zum Reichsbürgergesetz. Vom 27. September 1938) przełożył J. Sas-Wisłocki (Weryfikacja adwokatury w Niemczech, „Współczesna Myśl Prawnicza” 1938, nr 12, s. 58-61). Generalną ocenę ustaw norymberskich daje F. Połomski, Ustawodawstwo rasistowskie III Rzeszy i jego stosowanie na Górnym Śląsku, Katowice 1970, s. 105 n. Niemiecki tekst obu ustaw norymberskich, wraz z przekładem na język polski, http://www.kosciol.pl/article.php/20040914222342895?query=Ustawy+ Norymberskie (dostęp: 2.11.2020).

15 L. Górnicki, T. Kruszewski, op. cit., s. 48-49 n. 
rozporządzenie wykonawcze do tej ustawy z 14 listopada tegoż roku ${ }^{16}$. Wprowadzono także ustawę o ochronie krwi i czci niemieckiej oraz pierwsze rozporządzenie wykonawcze do tej ustawy ${ }^{17}$. Od ogłoszenia tych zmian w prawie system prawny na ziemiach wcielonych nie różnił się więc niczym istotnym od Altreichu, czyli „Starej Rzeszy”.

Praktyka często jednak odbiegała od założeń doktrynalnych i do dziś nie jest w pełni jasne, jaki status prawny przysługiwał osobom fizycznym na ziemiach wcielonych. Zasady ustrojowe Trzeciej Rzeszy musiały tam siłą rzeczy oddziaływać na całe prawo prywatne, a co za tym idzie żywioł niemiecki miał wypierać elementy „narodowoobce”, szczególnie zaś Żydów. Mieli oni być stopniowo eliminowani i pozbawiani wszelkich praw. Sposoby naruszania zasady równego korzystania z praw osobistych i innych przepisów części ogólnej BGB, formalnie obowiązującego na ziemiach wcielonych od 1941 roku, były zróżnicowane. Nakazywano specjalny tryb pozdrawiania na ulicy czy oznakowania zewnętrznego podczas publicznego poruszania się. Przenoszono w ten sposób na dotychczasowe obszary polskie rozwiązania prawne z Altreichu. W pierwszym okresie drugiej wojny światowej istniał na tym polu spory bałagan. Nie wprowadzono jeszcze wszystkich przepisów niemieckich, stąd też gauleiterzy na ziemiach wcielonych sami tworzyli różniące się normy prawne, a ponadto często stosowano zupełnie odmienną praktykę. Dopiero po 1941 roku, z chwilą ostatecznego rozciągnięcia prawa Trzeciej Rzeszy na te ziemie, pogłębiała się ich unifikacja z Altreichem.

Wspomniane formalne rozciągnięcie na ziemie wcielone ustaw norymberskich, co w praktyce nastąpiło od 4 listopada 1941 roku, spowodowało problem interpretacyjny dotyczący Kraju Warty. Jak wiadomo, już rozporządzenie namiestnika Rzeszy Arthura Greisera wydane w połowie grudnia 1939 roku wprowadzało w Kraju Warty ustawy norymberskie ${ }^{18}$. Ponadto Greiser zastosował tu, od 6 sierpnia 1940 roku, własne reguły, znacznie ostrzejsze od ustaw norymberskich, albowiem zgodnie z nimi Żydem był w każdym wypadku potomek małżeństw mieszanych ${ }^{19}$. Tak więc od wejścia w życie tych przepisów obowiązywały na ziemiach wcielonych dokładne definicje Żydów i żydowskich mieszańców. Dnia 31 maja 1941 roku ogłoszono także drugie rozporządzenie wykonawcze do

16 Verordnung über die Einführung der Nürnberger Rassengesetze in den eingegliederten Ostgebieten. Vom 31 Mai 1941 - RGB1. I, Jg. 1941, s. 297; tekst podaje także K.M. Pospieszalski, Hitlerowskie „prawo” okupacyjne w Polsce. Wybór dokumentów, cz. 1. Ziemie „,wcielone”, Documenta Occupationis, t. 5, Poznań 1952, s. 142-143; zob. D. Majer, op. cit., s. 156. Tekst polski rozporządzenia o wprowadzeniu norymberskich ustaw rasowych na włączonych obszarach wschodnich zob. A. Konieczny, Wybór tekstów źródtowych z historii państwa i prawa. Okres okupacji hitlerowskiej na ziemiach polskich, Wrocław 1977, s. 40-41.

17 Zob. też RGB1. I, Jg. 1941, s. 297, Zweite Verordnung zur Ausführung des Gesetzes zum Schutze des deutschen Blutes und der deutschen Ehre. Vom 31 Mai 1941.

18 C. Madajczyk, Polityka III Rzeszy w okupowanej Polsce, t. 2, Warszawa, 1970, s. 216.

19 F. Celnikier, op. cit., s. 237. 
ustawy o ochronie krwi i czci niemieckiej, z którego wynikało, że przepisy rasowe ustaw norymberskich miały dotyczyć wyłącznie Niemców zamieszkujących na ziemiach wcielonych, a nie dotyczyły natomiast ludności polskiej ${ }^{20}$. Drugie rozporządzenie wykonawcze do ustawy o ochronie krwi i czci niemieckiej rozszerzało zastosowanie ustawy do Polaków obecnie uznanych za obywateli Rzeszy Niemieckiej, tak zwanych volksdeutschów. Według stanowiska doktryny ustawa miała zresztą dotyczyć wszystkich innych grup niepożądanych, zaliczonych do „narodowo obcych”. Zmierzała ona bowiem do uniknięcia sytuacji, gdy „można było oczekiwać potomstwa zagrażającego zachowaniu czystości rasy" ${ }^{21}$. Zagrożenie to istniało nie tylko w stosunku do Żydów i Polaków, lecz także przede wszystkim odnośnie do Romów i Murzynów.

Dnia 25 kwietnia 1943 roku ogłoszono dwunaste rozporządzenie wykonawcze do ustawy o obywatelstwie Rzeszy ${ }^{22}$. Rozciągało ono ostatecznie na ziemie wcielone podział na obywateli Rzeszy i przynależnych do państwa, przypominając, że ta ostatnia kategoria nie jest jednoznaczna z pojęciem obywatelstwa. Żydzi i Romowie w świetle $\S 5$ pierwszego rozporządzenia wykonawczego do ustawy o obywatelstwie Rzeszy z 14 listopada 1935 roku w żadnym wypadku nie mogli uzyskać obywatelstwa Rzeszy, ani bezwarunkowego, ani z możliwością jego odwołania ${ }^{23}$. Żydowscy mieszańcy I stopnia mieli być traktowani tak jak Żydzi.

Ostatnie rozporządzenie wykonawcze do ustawy o obywatelstwie Rzeszy z 1 lipca 1943 roku stanowiło, że czyny karalne Żydów w przyszłości rozpatrywane będą już nie przez władze sądowe, lecz przez policję, przez co wykluczono ich zupełnie z systemu prawnego (§ 1). Mienie zmarłego Żyda przypadało państwu $(\S 2)^{24}$.

W stosunku do Żydów rasizm przekreślał więc całkowicie ideę i koncepcję praw podmiotowych prywatnych.

20 RGB1. I, Jg. 1941, s. 297 — Zweite Verordnung zur Ausführung des Gesetzes zum Schutze des deutschen Blutes und der deutschen Ehre. Vom 31. Mai 1941. Tekst podaje także K.M. Pospieszalski, Documenta Occupationis, t. 5, s. 143-144.

21 D. Majer, op. cit., s. 70-71.

22 RGB1. I, Jg. 1943, s. 268 - Zwölfte Verordnung zum Reichsbürgergesetz. Vom 25. April 1943. Tekst także K.M. Pospieszalski, Documenta Occupationis, t. 5, s. 165-166.

${ }^{23}$ Erste Verordnung zum Reichsbürgergesetz. Vom 14. November 1935, RGB1. I, Jg. 1935, s. 1333 .

24 RGB1. I, Jg. 1943, s. 372 - Dreizehnte Verordnung zum Reichsbürgergesetz. Vom 1. Juli 1943. Żydzi nie podlegali nawet przepisom karnym odnoszącym się do Polaków; zob. RGB1. I, Jg. 1941, s. 372 - Verordnung über die Strafrechtspflege gegen Polen und Juden in den eingegliederten Ostgebieten. Vom 4. Dezember 1941. 


\section{Eliminowanie Żydów ze stosunków prawnych prawa cywilnego}

\subsection{Oznakowanie Żydów}

Drastycznym przejawem ingerencji $\mathrm{w}$ prawa podmiotowe prywatne jednostek było narastające stopniowo zewnętrzne oznakowanie Żydów. Naruszało to, poza innymi przepisami, $\S 12 \mathrm{BGB}$, dotyczący ochrony nazwiska. W sposób charakterystyczny dla „państwa wodzowskiego”, w którym nie liczono się $\mathrm{z}$ tradycyjnie przyjętą hierarchią aktów prawnych, pozbawiano jednostki praw podmiotowych, gwarantowanych im konstytucją i kodeksem cywilnym, co poza samym nazwiskiem oraz imieniem dotyczyło również zwłaszcza wizerunku, czci oraz wolności osobistej. Proces ten zapoczątkował okólnik Ministerstwa Spraw Wewnętrznych Rzeszy z 25 czerwca 1934 roku, w którym zakazano Żydom zmieniania nazwisk ${ }^{25}$. Na mocy tego okólnika osoba wnioskująca o zmianę nazwiska lub imienia była zobowiązana do przedstawienia między innymi dowodu aryjskiego pochodzenia ${ }^{26}$. Dołączony do okólnika z 25 czerwca 1934 roku załącznik regulował, że jeżeli Aryjczyk nosił żydowskie nazwisko, powinien złożyć wniosek o jego zmianę. Dotyczyło to w praktyce całej rodziny takiej osoby. Należało zbadać, czy nazwisko potocznie kojarzone jako żydowskie (podano przykłady takich nazwisk: Hirsch, Goldschmidt) w rzeczywistości nie oznaczało, że dana osoba jest pochodzenia żydowskiego. Regulacja dotyczyła także sytuacji, gdy Aryjczyk miał żydowskie imię (podano przykłady takich imion: Salomon, Israel, Moses). Nie można było przyjmować nazwisk jednoznacznie żydowskich, jak choćby Krotoschiner, Hamburger, Darmstädter. Wnioski Żydów o zmianę nazwisk lub imion w każdej sytuacji należało odrzucić ${ }^{27}$. Ustawa z 5 stycznia 1938 roku o zmianie imion i nazwisk przewidywała, że istnieje możliwość cofnięcia

25 MBliV, Jg. 1934, szp. 886, Änderung von Familiennamen und Vornamen, RdErl. d. MdI. v. 25. 6. 1934 I Z $10 \mathrm{IV}$, A.I ust. 4 pkt 3; D. Majer, op. cit., s. 110. Już wcześniej podjęto się próby zatamowania fali zmiany nazwisk; na mocy okólnika z 17 stycznia 1934 r. Minister Spraw Wewnętrznych prosił o dostarczenie mu sprawozdań o wszystkich zmianach nazwisk (liczba podań uwzględnionych i odrzuconych) od 1 grudnia 1932 do 31 maja 1934 r.; zob. MBliV, Jg. 1934, szp. 118, Änderung von Familiennamen. RdErl. d. MdI. v. 17. 1. $1934-I$ Z3/34.

${ }^{26}$ Nowelizacja tego przepisu z 10 sierpnia 1937 r. dodawała, że jeżeli „niemieckokrwiści” mieli żydowskie nazwiska, należało sprawdzić, czy nie mieli żydowskiej domieszki krwi. Trzeba też było przeprowadzić dowód aryjskiego pochodzenia aż do dziadków. W razie wątpliwości istniała konieczność odwołania do Reichsstelle für Sippenforschung. MBliV, Jg. 1937, szp. 1700, Änderung von Familiennamen und Vornamen, RdErl. d. RuPrMdI. v. 10. 8. 1937-I B' Z Allg. 21 II, ust. (1) i (2).

27 Anlage. Richlinien für die Bearbeitung der Anträge auf Änderung des Familiennamens; zob. VII. Judennamen. MBliV, Jg. 1934, szp. 886. 
dokonanych wcześniej, a także w przyszłości zmian imion i nazwisk ${ }^{28}$. Od połowy 1938 roku Żydzi otrzymywali specjalne dowody tożsamości (Kennkarten), w których wprowadzono oznaczenie ich słowem ,Żyd”. W tym samym czasie wydane zostało drugie rozporządzenie wykonawcze do ustawy o zmianie imienia i nazwiska, z 17 sierpnia 1938 roku, nakazujące Żydom nadawać swoim dzieciom tylko imiona żydowskie, a od 1 stycznia 1939 roku każdy Żyd musiał nosić drugie imię Israel, Żydówka zaś Sara ${ }^{29}$.

Na podstawie odrębnych przepisów zakazano Żydom posługiwania się nazwiskami uznanymi za niemieckie. Przepisom tym towarzyszyło orzecznictwo sądowe, w którym odmawiano nadawania dzieciom imion ,uznanych za żydowskie" $^{30}$. Potwierdzeniem tej polityki była także ustawa z 3 listopada 1938 roku o stanie cywilnym ${ }^{31}$. Podczas gdy rozporządzenie z 22 lipca 1938 roku wprowadziło obowiązek posiadania tak zwanych kenkart, to przepisy wykonawcze wprowadziły odrębną grupę tych dokumentów dla Żydów ${ }^{32}$.

Wspomniane rozporządzenie z 17 sierpnia 1938 roku nakazywało Żydom używać w obrocie codziennym i przy wszystkich czynnościach prawnych tylko semickich imion. W paszportach, jeżeli otrzymywał je „nie-Aryjczyk”, wbijano od 1938 roku literę „J"33. Tak więc prawodawstwo niemieckie znalazło się już o krok od powrotu do średniowiecza, w którym publicznie oznakowywano

${ }^{28}$ RGB1. I, Jg. 1933, s. 141 - Gesetz über die Änderung von Familiennamen und Vornamen. Vom 5. Januar 1938.

29 RGB1. I, Jg. 1938, s. 9 - Gesetz über die Änderung von Familiennamen und Vornamen. Vom 5. Januar 1938. Z ustawy wynikał ściśle restrykcyjny tryb zmiany imienia i nazwiska; zob. też drugie rozporządzenie wykonawcze do ustawy z 5 stycznia 1938 r. o zmianie imienia i nazwiska z 17 sierpnia 1938 r. (RGB1. I, Jg. 1938, s. 1044, Zweite Verordnung zur Durchführung des Gesetzes über die Änderung von Familiennamen und Vornamen. Vom 17. August 1938). Por. ponadto okólnik RMdI z 18 sierpnia 1938 r., Vornamen. RdErl d. RMdI v. 18. 8. 1938 - I d 42 X/38-5501 b (MBliV, szp. 1346), który zawierał w załączniku wykaz imion uznanych za żydowskie (szczególnie ostrożnie należało nadawać dzieciom imiona nieniemieckie, które musiały być powszechnie znane i nie być imionami stricte hebrajskimi), a także okólnik z 18 lutego 1939 r. (Vornamen. RdErl d. RMdI v. 18. 2. 1939 - Id 113-5501 b., MBliV, szp. 350). Ten ostatni okólnik nakazywał nadawać imiona niemieckie lub nordyckie, a inne tylko w szczególnych wypadkach i to przy założeniu nie będą się źle wymawiały w języku niemieckim; z piśmiennictwa zob. A. Püschel, “...der Angeklagte ist Jude”. Die Auswirkungen der antisemitischen Gesetzgebung auf Bürger der Provinz Brandenburg 1933-1945, s. 72 n. (tutaj wybrane dokumenty z przesłuchań policyjnych oraz orzeczenia sądów).

${ }^{30}$ F. Ryszka, Państwo stanu wyjatkowego. Rzecz o systemie państwa i prawa Trzeciej Rzeszy, Wrocław 1985, s. 443; K. Jonca, Polityka narodowościowa Trzeciej Rzeszy na Ślasku Opolskim (1933-1940). Studium polityczno-prawne, Katowice 1970, s. 265; F. Połomski, Ustawodawstwo rasistowskie..., s. 201-206.

31 RGB1. I, Jg. 1937, s. 1146 - Personenstandgesetz. Vom 3. November 1937. Ustawa obowiązywała dopiero od 1 lipca 1938 r.; zob. też F. Ryszka, op. cit., s. 443.

32 RGB1. I, Jg. 1938, s. 913 - Verordnung über Kennkarten. Vom 22. Juli 1938; RGB1. I, Jg. 1938, s. 922 - Dritte Bekanntmachung über Kennkartenzwang. Vom 23. Juli 1938.

33 RGB1. I, Jg. 1938, s. 1342 — Verordnung über Reisepässe von Juden. Vom 5. Oktober 1938; D. Majer, op. cit., s. 111. 
Żydów na ulicach. Obowiązek oznakowania Żydów w miejscach publicznych, co dotyczyło także ubrań roboczych, wprowadził Minister Spraw Wewnętrznych Rzeszy rozporządzeniem z 1 września $1941 \mathrm{roku}^{34}$. Za złamanie tego przepisu groziła kara grzywny do $500 \mathrm{RM}$ lub więzienia do 1 miesiąca.

Dnia 30 marca 1942 roku wydane zostało zarządzenie szefa Sipo o publicznym oznakowaniu tarczą Dawida mieszkań zajmowanych przez Żydów, która musiała być umieszczona obok tabliczki z imieniem i nazwiskiem ${ }^{35}$. Wprowadzono także specjalne dni i godziny, w których Żydzi mogli robić zakupy w sklepach. Rozporządzenie z 1 września 1941 roku ograniczyło z kolei prawo Żydów do poruszania się poza miejscem zamieszkania - mogło to nastąpić tylko za zezwoleniem miejscowego urzędu policji. Już wcześniej rozporządzenie z 28 listopada 1938 roku, podjęte $\mathrm{w}$ ramach akcji niszczenia życia żydowskiego po sławnym pogromie Żydów zwanym nocą kryształową, zakazało im korzystać z wszystkich urządzeń kulturalnych i sportowych, także z parków publicznych, oraz poruszać się na ważniejszych ulicach i placach ${ }^{36}$. Na mocy rozporządzenia z 11 listopada 1938 roku Żydzi nie mogli uzyskiwać pozwolenia na broń ${ }^{37}$, a na podstawie kolejnego rozporządzenia, z 19 listopada, mieli utrudniony dostęp do opieki społecznej ${ }^{38}$. Zarządzenie z 16 czerwca 1939 roku ograniczało dostęp Żydom do uzdrowisk i kąpielisk ${ }^{39}$. Kolejne zarządzenie, z 14 sierpnia 1939 roku, usuwało ich ze szkolnictwa publicznego ${ }^{40}$. Zarządzeniem z 26 grudnia 1941 roku zabroniono Żydom korzystać z publicznych budek telefonicznych na ulicach ${ }^{41}$. Zarządzeniem Ministra Komunikacji Rzeszy z lipca 1942 roku Żydzi korzystający z zezwolenia komunikacyjnego pod żadnym pozorem nie mogli korzystać

34 RGB1. I, Jg. 1941, s. 547 - Polizeiverordnung über die Kennzeichnung der Juden. Vom 1. September 1941. Weszło ono w moc prawną 14 dni od dnia opublikowania (czyli 19 września 1941 r.). D. Majer pisze, że rozporządzenie to sporządził Szef Sipo Rzeszy (Policji Bezpieczeństwa); zob. D. Majer, op. cit., s. 111.

35 Bekanntmachung über die Kennzeichnung jüdischer Wohnungen. Vom 30. März 1942. Uzyskało ono moc prawną z dniem 15 kwietnia 1942 r.; zob. B. Blau, op. cit., nr 375.

36 RGB1. I, Jg. 1938, s. 1676. Polizeiverordnung über das Auftreten der Juden in der Öffentlichkeit. Vom 28. November 1938.

37 RGB1. I, Jg. 1938, s. 1573, Verordnung gegen den Waffenbesitz der Juden. Vom 11. November 1938. Było to jedno z posunięć antyżydowskich podjętych po Kristallnacht.

38 RGB1. I, Jg. 1938, s. 1649, Verordnung über die öffentliche Fürsorge für Juden. Vom 19. November 1938. Zob. też MBliV, Jg. 1939, szp. 1297, Durchführung der VO. über die öffentliche Fürsorge für Juden. RdErl. d. RAM. u. d. RMdI. v. 25. 5. 1939 - II b 2790/39 u. V W I 43/39-7808.

39 MBliV, Jg. 1939, szp. 1291, Juden in Bädern und Kurorten. RdErl. D. RMdI zgl i. R. d. RMfBuP. v. 16. 6. 1939 - I e 16 XVII/39-5012e. Żydzi mogli przebywać w nich tylko na wyraźne skierowanie lekarskie, ale najpierw mieli być kierowani do ośrodków należących do Żydów.

40 MBliV, Jg. 1939, szp. 1986, Ausf.- Anw. zu Art. II der 10. VO. zum Reichsbürgerges. v. 4.7. 1939 (RGBl. I S. 1097). RdErl. D. RMfWEuV. zgl. i. R. d. RMdI. v. 14. 8. $1939-$ E I b 462 (b) u. I e 561 II/39-5012. Wcześniej, na mocy Reichshabilitationsordnung. Vom 13. Dezember 1934, ogłoszono, że habilitant musi mieć „,pochodzenie aryjskie”; zob. B. Blau, op. cit., nr 61.

${ }^{41}$ Anordnung der Aufsichtsbehörde über die Benutzung öffentlicher Fernsprechstelle durch Juden. Vom 26. Dezember 1941; zob. B. Blau, op. cit., nr 360. 
z poczekalni i restauracji dworcowych, a także z innych urządzeń ${ }^{42}$. Mogli jedynie wejść do środka masowej komunikacji, bez wcześniejszego oczekiwania na dworcu. Według wytycznych Ministra Spraw Wewnętrznych Rzeszy z 10 października 1941 roku Żydzi mogli zajmować miejsca siedzące, tylko gdy nie było stojących „Aryjczyków”. W razie tłoku w środku komunikacji Żydom w ogóle było zabronione do niego wsiadać ${ }^{43}$. Nieco później, 16 października 1941 roku, ten sam minister wydał rozporządzenie zakazujące w każdym wypadku z korzystania przez Żydów z autobusów. W kolejnym rozporządzeniu z 24 marca 1942 roku w praktyce zakazano Żydom w ogóle podróżowania środkami komunikacji publicznej, z określonymi wyjątkami ${ }^{44}$. Zezwolenie na przejazd mogło dotyczyć tylko określonej gminy, wydawane było raz na rok i dotyczyć miało pracowników, jeżeli miejsce pracy leżało więcej niż o 1 godzinę marszu lub o 7 kilometrów (żydowscy uczniowie otrzymywali zgodę na dojazd do szkoły, jeżeli ta odległość przekraczała 5 kilometrów) od miejsca zamieszkania. Przepisy te zbiegły się z masowymi wywózkami Żydów na wschód i miały ułatwiać deportacje ${ }^{45}$.

Hitlerowskiemu reżimowi nie wystarczało jednak całkowite pozbawienie Żydów praw publicznych i uszczuplenie tak zwanych praw prywatnych do granic biologicznej egzystencji, ale — wraz z wybuchem drugiej wojny światowej - coraz bardziej narastały złowieszcze poglądy o konieczności całkowitego wykluczenia z niemieckiej wspólnoty prawnej wszystkich „nie-Aryjczyków”, wraz $\mathrm{z}$ mieszańcami. Osławione jedenaste rozporządzenie wykonawcze do ustawy o obywatelstwie Rzeszy z 25 listopada 1941 roku położyło kres możliwości jakiegokolwiek korzystania przez Żydów w Trzeciej Rzeszy z praw podmiotowych ${ }^{46}$.

\subsection{Usuwanie Żydów z wolnych zawodów i z obrotu profesjonalnego w ogólności}

Obywatele polscy pochodzenia żydowskiego na ziemiach wcielonych zostali poddani ustawodawstwu Trzeciej Rzeszy obowiązującemu Żydów w Niemczech jeszcze przed wybuchem drugiej wojny światowej.

42 Anordnung über die Benutzung öffentlicher Verkehrsmittel. Vom 7. Juli 1942; zob. B. Blau, op. cit., nr 396.

${ }^{43}$ Richtlinien für die Durchführung der Polizeiverordnung über die Kennzeichnung der Juden. Vom 10. Oktober 1941; zob. B. Blau, op. cit., nr 339.

44 Anordnung über die Benutzung öffentlicher Verkehrsmittel. Vom 24. April 1942; zob. B. Blau, op. cit., nr 377.

45 D. Majer, op. cit., s. 113.

46 RGB1. I, Jg. 1941, s. 722 - Elfte Verordnung zum Reichsbürgergesetz. Vom 25. November 1941 , por. zwłaszcza $§ 2$. Sytuację prawną niearyjskiej wdowy i dzieci z małżeństwa mieszanego z Żydem uregulowało zarządzenie MSW z 12 grudnia 1941 r. do jedenastego rozporządzenia wykonawczego. MBliV, Jg. 1941, szp. 2197. Durchf.-Best. zu § 10 der Elften VO. zum Reichsbürgerges. RdErl. d. RMdI. V. 12. 12. 1941 - II 6043/41-6100a. 
W zakresie spraw związanych z zawieraniem umów już w pierwszym okresie Trzeciej Rzeszy przeważały ograniczenia dotyczące możliwości świadczenia usług w ramach tak zwanych wolnych zawodów, a zwłaszcza wymagających licencji państwowej, następnie zaś innych zawodów. Minowicie z jednej strony ograniczano „nie-Aryjczykom” dostęp do wykonywania zawodu adwokata, a $\mathrm{z}$ drugiej ograniczano, a następnie całkowicie uniemożliwiono dostęp obywatelom do usług adwokackich świadczonych przez „nie-Aryjczyków”47. Do 1935 roku przeważały ograniczenia faktyczne w postaci bojkotów żydowskich adwokatów. Pod koniec 1935 roku Minister Sprawiedliwości Rzeszy wydał zarządzenie o niedopuszczalności powierzania adwokatom żydowskim występującym z urzędu spraw z zakresu prawa ubogich ${ }^{48}$. Od tego momentu rozpoczęło się systematyczne uniemożliwianie klientom korzystania z usług żydowskich adwokatów. W 1938 roku zakazano Żydom prowadzenie postępowań upadłościowych, ugodowych i przymusowych ${ }^{49}$. Żydzi nie mogli być także opiekunami prawnymi i kuratorami. Jeśli toczono spory spadkowe o zagrodę dziedziczną, nie można było także wynajmować żydowskich adwokatów ${ }^{50}$.

Piąte rozporządzenie wykonawcze do ustawy o obywatelstwie Rzeszy z 27 lipca 1938 roku ostatecznie wyeliminowało Żydów ze środowiska adwokatów. Nie uwzględniono nawet postulatów, by nie usuwać tak zwanych zasłużonych Żydów, kombatantów pierwszej wojny światowej ${ }^{51}$. Adwokaci byli teraz wyłącznie „Aryjczykami” i mogli obsługiwać klientów „,aryjskich”, choć wyjątkowo mogli też świadczyć pomoc prawną nielicznym klientom żydowskim ${ }^{52}$.

47 D. Majer, op. cit., s. 85 n.

$48 \mathrm{Nr} 364$ Auswahl von Armenanwälten, Pfichtverteidigern, Konkursverwaltern und dergl., Allgemeineverfügung des Reichsjustizministers vom 19.12.1935, (IVb 8040), Deutsche Justiz, Jg. 1935, s. 1858; zob. D. Majer, op. cit., s. 87.

49 Runderlass des Reichsinnenministers vom 17.10.1938 - V W II 1/38-8200, Berücksichtigung der Grundsätze der Rassengesetzgebung bei Bestellung von Einzelpersonen zu Vormündern, Pflegern, Helfern oder Beiständen, MBliV, Jg. 1938, szp. 1722, które wykluczało Żydów, jak też żydowskich mieszańców I stopnia, a nawet tylko osoby pozostające w związku małżeńskim z Żydem; zob. D. Majer, op. cit., s. 87.

50 Każdy członek postępowania w sprawie zagród dziedzicznych musiał być aryjskiego pochodzenia; zob. RGB1. I, Jg. 1933, s. 749 - Erste Durchführungsverordnung zum Reichserbhofgesetze, insbesondere über Einrichtung und Verfahren der Anerbenbehörden. Vom 19. Oktober 1933, $\S 7$; D. Majer, op. cit., s. 88.

51 Zob. przytaczane już rozporządzenie: RGB1. I, Jg. 1938, s. 1403 - Fünfte Verordnung zum Reichsbürgergesetz. Vom 27. September 1938. § 1 pkt 1 rozporządzenia nakazywał usunąć wszystkich Żydów do 31 grudnia 1938 r. Uzupełnieniem było szóste rozporządzenie wykonawcze z 31 października 1938 r., które usuwało Żydów z szeregów doradców patentowych, zob. RGBl. I, Jg. 1938, s. 1545 - Sechste Verordnung zum Reichsbürgergesetz. Vom 31. Oktober 1938. Zob. D. Majer, op. cit., s. 88; F. Połomski, Ustawodawstwo rasistowskie..., s. 210.

52 Jeżeli adwokat był członkiem partii, to obowiązywał go od 1934 r. całkowity zakaz obsługiwania klientów żydowskich. W 1935 r. zakaz rozszerzono na wszystkich członków Narodowosocjalistycznego Związku Rzeczników Prawa. W 1938 r. objął on kolejne grupy organizacji partyjnych; zob. D. Majer, op. cit., s. 89-90. 
Dla Żydów stworzono pojęcie „konsultantów”, ich klientami mogli być wyłącznie Żydzi ${ }^{53}$. Na podstawie prawa notarialnego z 13 lutego 1937 roku Żydzi nie mogli także wykonywać tego zawodu ${ }^{54}$.

Żydzi na mocy rozporządzenia z 11 stycznia 1936 roku nie mogli być doradcami w sprawach podatkowych ${ }^{55}$. Rozporządzenie z 29 czerwca 1936 roku rozszerzało ten zakaz na rzeczoznawców w sprawach obrotu dewizowego ${ }^{56}$. Żydówki zostały natomiast pozbawione prawa wykonywania zawodu położnej, na mocy ustawy z 21 grudnia 1938 roku, a następnie w 1939 roku także bycia opiekunką noworodków i starszych dzieci ${ }^{57}$. Rozporządzeniem z 24 października 1939 roku uniemożliwiono Żydom bycie członkami zarówno ochotniczej, jak i zawodowej straży pożarnej ${ }^{58}$.

Równolegle wprowadzono analogicznie zasady odnośnie do lekarzy ${ }^{59}$. Już na mocy rozporządzenia z 22 kwietnia 1933 roku wprowadzono licencje dla lekarzy, stomatologów i dentystów pracujących na rzecz kas chorych, z których Żydzi byli automatycznie wykluczeni, co powodowało niemożność leczenia chorych $\mathrm{w}$ systemie ubezpieczeniowym ${ }^{60}$. W 1934 roku wprowadzono zasadę,

53 RGB1. I, Jg. 1935, s. 1478 - Gesetz zur Verhütung von Missbräuchen auf dem Gebiete der Rechtsberatung. Vom 13. Dezember 1935. RGB1. I, Jg. 1935, s. 1481; Verordnung zur Ausführung des Gesetzes zur Verhütung von Missbräuchen auf dem Gebiete der Rechtsberatung. Vom 13. Dezember 1935. § 5 tego rozporządzenia brzmiał następująco: „Żydom pozwolenie nie będzie udzielane"; zob. D. Majer, op. cit., s. 88.

${ }^{54}$ RGB1. I, Jg. 1937, s. 191 - Reichsnotarenordnung. Vom 13. Februar 1937, § 3; zob. F. Potomski, Ustawodawstwo rasistowskie..., s. 63.

55 RGB1. I, Jg. 1936, s. 11 - Verordnung zur Durchführung des $\$ 107$ a der Reichsabgabeordnung. Vom 11. Januar 1936, § 6 ust. 1 „Żydom nie będzie udzielana licencja”; zob. F. Połomski, Ustawodawstwo rasistowskie..., s. 63.

56 RGB1. I, Jg. 1936, s. 524 - Verordnung über die geschäftsmäßige Hilfeleistung in Devisensachen. Vom 29. Juni 1936, § 8 ust. 1 „Żydom nie będzie udzielana licencja”; zob. F. Połomski, Ustawodawstwo rasistowskie..., s. 63.

57 RGB1. I, Jg. 1938, s. 1893 - Hebammengesetz. Vom 21. Dezember 1938, § 7 i 11; RGB1. I, Jg. 1939, s. 2239 - Erste Verordnung über berufsmäßige Ausübung der Säuglings- und Kinderpflege und die Errichtung von Säuglings- und Kinderpflegeschulen (Säuglings- und Kinderpflegeverordnung - SuKPflV -). Vom 15. November 1939, § 21 i RGBl. I, Jg. 1939, s. 2244 - Zweite Verordnung über berufsmäßige Ausübung der Säuglings- und Kinderpflege und die Errichtung von Säuglings- und Kinderpflegeschulen (Säuglings- und Kinderpflegeverordnung - SuKPflV -). Vom 15. November 1939, § 14.

58 RGB1. I, Jg. 1939, s. 2096 — Dritte Durchführungsverordnung zum Gesetz über das Feuerlöschwesen (Organisation der Freiwilligen Feuerwehr). Vom 24. Oktober 1939, § 4. RGB1. I, Jg. 1939, s. 2100 — Vierte Durchführungsverordnung zum Gesetz über das Feuerlöschwesen (Organisation der Pflichtfeuerwehr). Vom 24. Oktober 1939, § 7.

59 O prześladowaniu lekarzy żydowskich pisze R. Jütte, Die Vertreibung jüdischer und „staatsfeindlicher" Ärztinnen und Ärzte, [w:] Medizin und Nationalsozialismus. Bilanz und Perspektiven der Forschung, red. R. Jütte, Göttingen 2011, s. 83 n.

${ }^{60}$ RGB1. I, Jg. 1933, s. 222 - Verordnung über die Zulassung von Ärzten zur Tätigkeit bei den Krankenkassen. Vom 22. April 1933, art. II ust. 2 wykluczał osoby „niearyjskie”; zob. D. Majer, op. cit., s. 90-91. 
że licencja dla lekarzy, a w 1935 roku dla stomatologów i dentystów nie mogła być udzielona, także gdy lekarz, stomatolog lub dentysta mieli małżonka „,niearyjskiego"61. Potwierdzała to nowa ustawa lekarska z 13 grudnia 1935 roku, która wymagała sprawdzania czystości rasowej przy nominacji na lekarza ${ }^{62}$. Był to tylko kolejny krok do wprowadzenia całkowitego zakazu wykonywania zawodu. Następnie usunięto Żydów z funkcji kierowniczych w lecznictwie - na mocy $\S 6$ drugiego rozporządzenia wykonawczego do ustawy o obywatelstwie Rzeszy z 21 grudnia 1935 roku $^{63}$. „Aryjscy” pacjenci ostatecznie utracili możliwość leczenia się u „nie-Aryjczyków” na mocy dalszych przepisów z 1938 i 1939 roku. Co do lekarzy zakaz leczenia ,aryjskich” pacjentów wprowadzono w czwartym rozporządzeniu wykonawczym do ustawy o obywatelstwie Rzeszy z 25 lipca 1938 roku $(\S 4)^{64}$. Od tej pory zwano ich „doradcami medycznymi” (Krankenbehandler). W ramach kasy chorych mogli leczyć tylko Żydów ${ }^{65}$. Podobny zakaz odnośnie do dentystów, techników dentystycznych i weterynarzy oraz aptekarzy wprowadzono w ósmym rozporządzeniu wykonawczym do ustawy o obywatelstwie Rzeszy z 17 stycznia 1939 roku $^{66}$. Czwarte rozporządzenie wykonawcze umożliwiało także wypowiedzenie umowy najmu lokalu lekarzowi żydowskiemu gabinetu (§ 7). Zbliżone ograniczenie dotyczyły wykonywania zawodu farmaceutów. Artykuł 3 pierwszego rozporządzenia wykonawczego do ustawy o wydzierżawianiu i administrowaniu aptek publicznych wykluczał możliwość, by Żydzi mogli zostać dzierżawcami ${ }^{67}$. Rozporządzenie uniemożliwiało Żydom także bycie właścicielem apteki. Kolejne rozporządzenie z 8 października 1937 roku o zatrudnianiu farmaceutów, wśród wymogów wykonywania zawodu

61 Prüfungsordnung für Ärzte und Zahnärzte. Vom 5. Februar 1934; zob. B. Blau, op. cit., $\mathrm{nr}$ 45, RGBl. I, Jg. 1935, s. 192 - Verordnung über die Zulassung von Zahnärzten und Dentisten bei den Krankenkassen. Vom 13. Februar 1935. Podobnie odnośnie do weterynarzy, ordynacja dla weterynarzy Rzeszy z 3 kwietnia 1936 r., RGBl. I, Jg. 1936, s. 347 - Reichstierärzteordnung. Vom 3. April 1936 (zob. § 3 ust. 5); zob. D. Majer, op. cit., s. 91-92.

62 RGB1. I, Jg. 1935, s. 1433 - Reichsärzteordnung. Vom 13. Dezember 1935. § 3 ust. 5, wykluczał lekarzy „niebędących krwi niemieckiej” lub mających małżonka „niemającego pochodzenia z krwi niemieckiej”; zob. F. Połomski, Ustawodawstwo rasistowskie..., s. 63, 209.

63 RGB1. I, Jg. 1935, s. 1524 - Zweite Verordnung zum Reichsbürgergesetz. Vom 21. Dezember 1935; zob. D. Majer, op. cit., s. 91.

64 RGB1. I, Jg. 1938, s. 969 — Vierte Verordnung zum Reichsbürgergesetz. Vom 25. Juli 1938; zob. R. Jütte, Jüdische „Krankenbehandler”, [w:] Medizin und Nationalsozialismus ..., s. 261 n.; F. Połomski, Ustawodawstwo rasistowskie..., s. 209.

65 RGB1. I, Jg. 1938, s. 1391 - Verordnung über die Teilnahme von Juden an der kassenärztlichen Versorgung. Vom 6. Oktober 1938.

66 RGB1. I, Jg. 1939, s. 47 — Achte Verordung zum Reichsbürgergesetz. Vom 17. Januar 1939. Zgodnie z $§ 1$ ich dyplomy wygasały z dniem 31 stycznia 1939 r., podejmowanie dalszej działalności w podanych zawodach zostało na mocy $\S 2$ zakazane. Istniała możliwość powierzenia im dotychczasowych funkcji, ale tylko w stosunku do Żydów (§ 3); zob. D. Majer, op. cit., s. 91.

67 RGBl. I, Jg. 1936, s. 317 - Erste Verordnung zum Gesetz über die Verpachtung und Verwaltung öffentlicher Apotheken. Vom 26 März 1936. 
żądało poświadczenia, że kandydat nie jest Żydem (§ 3 ust. 4$)^{68}$. Następnym etapem było wyeliminowanie mieszańców żydowskich I i II stopnia, co nastąpiło we wspomnianym już ósmym rozporządzeniu wykonawczym do ustawy o obywatelstwie Rzeszy z 17 stycznia 1939 roku. Tryb zbywania aptek regulowało zarządzenie Ministra Spraw Wewnętrznych Rzeszy o „odżydzeniu praw do prowadzenia aptek" z 20 maja 1939 roku $^{69}$. Rozporządzeniem z 1 września 1939 roku zabroniono zatrudniać Żydów, w jakiejkolwiek formie, jako aptekarzy ${ }^{70}$.

Po Machtergreifung ,nie-Aryjczycy” znaleźli w trudnej sytuacji z powodu niemożności znalezienia jakiejkolwiek zajęcia zarobkowego, nasiliło się bowiem zjawisko masowego zwalniania ich z pracy. Pracodawcy naginali przy tym przepisy $\S 626$ BGB, który zezwalał na zwalnianie pracowników $\mathrm{z}$,ważnego powodu”. Doktryna interpretowała jako „ważny powód” przynależność rasową ${ }^{71}$. Początkowo istniały tu pewne ograniczenia, bo Są Pracy Rzeszy w wyroku z 25 listopada 1933 roku ograniczał zwolnienie tylko do sektora publicznego, głównie służby publicznej. W następnych latach obejmował jednak wyrokami sferę gospodarczą. Ponadto po nocy kryształowej pojawiły się głosy żądające odbierania Żydom emerytur. Coraz częściej zapadały też wyroki o nieprzysługiwaniu Żydom roszczeń do urlopu ${ }^{72}$.

Celem było całkowite wykluczenie Żydów ze sfery zawodowej, co usankcjonowało rozporządzenie z 12 listopada 1938 roku „o eliminacji Żydów z niemieckiego życia gospodarczego" "73. Ostatecznie pozbawienie Żydów podmiotowości w stosunkach pracy nastąpiło na mocy rozporządzenia z 3 października 1941 roku $^{74}$.

\section{Utrudnienia w zakresie dostępu Polaków do zawodów i niektóre ograniczenia praw osobistości}

$\mathrm{Na}$ ziemiach wcielonych do Rzeszy obowiązywały wszystkie utrudnienia w zakresie dostępu Polaków do wielu zawodów, co podważało uświęconą

68 RGB1. I, Jg. 1937, s. 1118 - Bestellungsordnung für Apotheker. Vom 8. Oktober 1937; zob. F. Połomski, Ustawodawstwo rasistowskie..., s. 209.

${ }^{69}$ MBliV, Jg. 1939, szp. 1137 - Entjudung von Apothekenbetriebsrechten. RdErl. d. RMdI zgl. i. R. d. RWiM. V. 20. 5. 1939. - IV e 3612/39-4052.

${ }^{70}$ RGB1. I, Jg. 1939, s. 1567 - Verordnung zur Bestellungsordnung für Apotheker. Vom 1. September 1939.

71 D. Majer, op. cit., s. 95; M. Broszat, op. cit., s. 180 n.

72 Sąd Pracy we Frankfurcie nad Menem, wyrok z 4 września 1940 r.; D. Majer, op. cit., s. 96.

73 RGB1. I, Jg. 1938, s. 1580 - Verordnung zur Ausschaltung der Juden aus dem deutschen Wirtschaftsleben. Vom 12. November 1938. Żydzi nie mogli między innymi być członkami żadnych organizacji gospodarczych (§ 3); zob. Majer, op. cit., s. 96; M. Broszat, op. cit., s. 207 n.

74 RGB1. I, Jg. 1941, s. 675 - Verordnung über Beschäftigung von Juden. Vom 3. Oktober 1941; RGB1. I, Jg. 1941, s. 681 — Verordnung zur Ausführung der Verordnung über Beschäftigung von Juden. Vom 31. Oktober 1941. 
przez nowożytne ustawodawstwo cywilne wolność świadczenia pracy. Jednym z pierwszych rasistowskich aktów prawnych, które tu wprowadzono, była ustawa urzędnicza z 1937 roku. Nastąpiło to rozporządzeniem z 24 grudnia 1939 roku, w związku z czym urzędnicy, którzy nie mieli pochodzenia „,aryjskiego”, zostali automatycznie wykluczeni ze służby ${ }^{75}$. Polscy adwokaci — jako tak zwani konsultanci prawni - mogli obsługiwać tylko Polaków, a więc ich sytuacja prawna było analogiczna do sytuacji żydowskich adwokatów w Niemczech ${ }^{76}$. Identyczne uregulowania obejmowały polskich lekarzy. Brakowało jakichkolwiek gwarancji ochrony danych osobowych, co uwidaczniało się także w dokumentach tożsamości.

W Kraju Warty i w prowincji górnośląskiej stosowano dwujęzyczny dokument o charakterze dowodu osobistego: Anmeldung zum polizeilichen Einwohnererfassunung - ,zgłoszenie celem policyjnego stwierdzenia ludności”, zwany potocznie ,palcówką”, ze względu na składany na nim odcisk palca, który miał zastępować fotografię właściciela i służyć jego identyfikacji. Zawierał on adres, dane personalne oraz informacje dotyczące wyznania, narodowości, języ$\mathrm{ka}$, którym posługiwano się $\mathrm{w}$ domu, służby $\mathrm{w}$ wojsku polskim i ewentualnego stopnia wojskowego, posiadanego zawodu i miejsca pracy, czasu zamieszkiwania na terenie ziem wcielonych, własności gruntów, nieruchomości, przedsiębiorstwa, liczby dzieci poniżej 12 roku życia, które znajdowały się we wspólnym domostwie. Na ziemiach wcielonych wydawano także kenkarty (,karta rozpoznawcza"), które miały postać dwukartkowej książeczki z zapisanymi danymi personalnymi, fotografią, odciskiem palca i podpisem właściciela. Jeżeli chodzi o osoby narodowości niemieckiej lub te, które przyjęły bądź zostały wciągnięte na volkslistę, na okładce kenkarty umieszczony był pionowy pas i dopisywano: Reichsdeutscher, Volksdeutscher, Deutsche Staatsangehörigkeit ${ }^{77}$. Drastyczne nierówności obowiązywały w sądach, gdy Polak próbował pozwać Niemca ${ }^{78}$.

Różnorakie ograniczenia dotyczyły możliwości przemieszczania się i zmiany miejsca zamieszkania, co miało istotne znaczenie zwłaszcza w perspektywie dotyczącej obrotu gospodarczego. Przede wszystkim miało to utrudnić kontakty z osobami zamieszkującymi w Generalnym Gubernatorstwie oraz w Altreichu, gdzie utrzymywano dawną granicę. W największym stopniu odnosiło się to ludności żydowskiej. Na początku wojny w Okręgu Rzeszy Poznań — późniejszym

75 RGB1. I, Jg. 1939, s. 2489 — Verordnung über die Einführung der reichsrechtlichen Vorschriften des Beamtenrechts und des Besoldungsrechts in den eingegliederten Ostgebieten. Vom 24. Dezember 1939.

76 D. Majer, op. cit., s. 147; M. Broszat, op. cit., s. 180.

77 Wybrane dokumenty represji i życia codziennego. Cechy formalne i tto historyczne. Opracowane na podstawie zasobu Archiwum Fundacji „Polsko-Niemieckie Pojednanie”, Fundacja „Polsko-Niemieckie Pojednanie", Warszawa 2009, s. 5, 8; zob. też K. Pospieszalski, Status prawny narodu polskiego na ziemiach zachodnich Rzeczypospolitej 1939-1945, [w:] Ekspertyzy i orzeczenia przed Najwyższym Trybunatem Narodowym, red. C. Pilichowski, Warszawa 1979, t. 2, s. 19, 20.

78 K. Pospieszalski, Status prawny narodu polskiego na ziemiach zachodnich Rzeczypospolitej 1939-1945, s. 25 i 26. 
Kraju Warty — miejscowy Wyższy Dowódca SS i Policji w listopadzie 1939 roku zakazał Żydom emigrowania i przeprowadzania się do innego miejsca. Zakazane było także przybywanie do tego okręgu innym Żydom. Te same regulacje dotyczyły Polaków. Władze hitlerowskie mogły natomiast same wysiedlać Polaków do Generalnego Gubernatorstwa, a Żydów, w dalszym okresie drugiej wojny światowej, przymusowo wywożono do ośrodków zagłady. Chociaż od listopada 1939 roku nie było możliwe przeprowadzenie się do nowego miejsca zamieszkania, to jednak na mocy rozporządzenia policyjnego z 26 czerwca 1941 roku, zapewne z powodów praktycznych, wprowadzono w ograniczonym stopniu możliwość przeprowadzki na terenie gminy zameldowania, a nawet poza jej teren, za każdorazowym zezwoleniem miejscowego urzędu policji ${ }^{79}$. Nie dotyczyło to napływania nowych Polaków z Generalnego Gubernatorstwa na ziemie wcielone, co do 1942 roku było jeszcze możliwe z pilnych powodów, między innymi zawarcia związku małżeńskiego. Później obowiązywał już całkowity zakaz takich podróży.

Nie tylko w prawa osobistości, ale i w podstawy gospodarcze, w prawo do zawierania umów, uderzały przepisy ograniczające, a nawet uniemożliwienie Żydom i Polakom podróżowania środkami komunikacyjnymi. Żydzi objęci zostali całkowitym zakazem podróżowania, który pogłębił się z chwilą zamknięcia ich w gettach. Natomiast jeżeli chodziło o Polaków, nawet w wypadku uzyskania zgody na przejazd istniała możliwość niewpuszczania ich do środka komunikacji, w razie zajęcia wszystkich miejsc przez Niemców ${ }^{80}$.

Prawa osobistości naruszały istniejące również na ziemiach wcielonych do Rzeszy ograniczenia co do możliwości utrzymywania kontaktów osobistych między Polakami a Niemcami. W szczególności kandydaci na urzędników na ziemiach wcielonych, będacy Niemcami, ale mający kontakty rodzinne z Polakami lub tylko utrzymujący z nimi stosunki towarzyskie, podlegali rozlicznym represjom i utrudnieniom $\mathrm{w}$ dostępie do stanowisk urzędniczych. Zakazane były jakiekolwiek towarzyskie czy seksualne kontakty Niemców z Polakami. Informował o tym okólnik namiestnika Greisera z 25 września 1940 roku. Urzędnik, który by utrzymywał kontakty seksualne z Polką, podlegał automatycznemu usunięciu ze służby. Niemce, która by utrzymywała stosunki z Polakiem, groziła karana zesłania do obozu koncentracyjnego, Polak podlegał karze śmierci ${ }^{81}$.

Zarządzenia Ministra Spraw Wewnętrznych Rzeszy z 10 listopada 1941 roku $^{82}$ i Ministra Sprawiedliwości z 27 czerwca 1941 roku $^{83}$, które powstały zgodnie z sugestiami namiestnika w Kraju Warty Arthura Greisera, zabraniały urzędnikom

79 D. Majer, op. cit., s. 158.

80 Ibidem, s. 159.

${ }^{81}$ K. Pospieszalski, Status prawny narodu polskiego na ziemiach zachodnich Rzeczypospolitej 1939-1945, s. 32.

82 D. Majer, op. cit., s. 146 (z: BA Koblenz).

${ }^{83}$ Erlass vom 27. Juni 1941 an die Oberlandesgerichtsspräsidenten und Generalstaatsanwälte in Danzig und Posen; za: BA Koblenz. 
„spowinowaconym i spokrewnionym” z Polakami wykonywania jakiejkolwiek działalności publicznej w Altreichu. Co ciekawe, nie mogli oni też być przenoszeni do Generalnego Gubernatorstwa. Urzędnicy uznani za przedstawicieli narodowości niemieckiej nie mogli zajmować się petentami „,narodowo obcymi”.

\section{Uzależnienie możliwości korzystania z praw podmiotowych prywatnych od zgody na wynarodowienie}

Na możliwość korzystania przez dawnych obywateli polskich nie tylko z praw publicznych, lecz także z prywatnych praw podmiotowych określony wpływ miała ich zgoda na wynarodowienie. Na ziemiach wcielonych do Rzeszy, podobnie w Generalnym Gubernatorstwie, stosowano dwie odmienne formy germanizacji: „zniemczanie” 84 oraz niemiecką listę narodową (Deutsche Volksliste $)^{85}$, oparte na samodzielnych podstawach prawnych. Podstawę procedury zniemczania osób niebędących narodowości niemieckiej, przede wszystkim Polaków, które zachowały korzystne cechy rasowe, stanowiło zarządzenie 17/II Reichsführera SS, komisarza Rzeszy ds. umacniania niemczyzny Heinricha Himmlera, z 9 maja 1940 roku $^{86}$. Przeznaczeni do zniemczenia traktowani byli jako bezpaństwowcy lub przynależni Rzeszy, a obywatelstwo niemieckie miano im nadać w bliżej nieokreślonej przyszłości. Podlegali oni obowiązkowi pracy. Jednak ich sytuacja prawna przedstawiała się pod pewnymi względami lepiej niż innych zatrudnionych przymusowo w Rzeszy. Nie mieli obowiązku zewnętrznego oznakowania, nie dotyczyły ich zakazy dotyczące przebywania w miejscach publicznych, używania publicznych środków lokomocji, godziny policyjnej i inne, wprowadzone i egzekwowane na podstawie zarządzenia Himmlera jako Reichsführera SS i szefa niemieckiej Policji z 8 marca 1940 roku. Zniemczani nie podlegali szczególnemu traktowaniu za stosunki cielesne z Niemcami. Stworzono dla nich możliwość zawierania małżeństw z Niemcami, na podstawie zarządzenia Urzędu Sztabowego Komisarza Rzeszy z 28 lipca 1942 roku. Przy dopuszczeniu ich do zawarcia małżeństwa, ponadto zaś w sytuacjach, w których wymagane było stwierdzenie równoprawnego stanowiska z Niemcami, otrzymywali oni zgodnie z zarządzeniem Komisarza Rzeszy z 25 marca 1942 roku — dokumenty

84 Więcej F. Połomski, Rasistowskie przesłanki hitlerowskiej polityki ,zniemczania”, SnFiZH 7 , 1981, s. 167-192.

85 Odnośnie do sytuacji osób wpisanych na niemiecką listę narodowościową po wojnie w Polsce zob. S. Bykowska, Karać czy rehabilitować? Powojenne ustawodawstwo polskie wobec osób wpisanych na Niemiecką Listę Narodowościowa, „Czasopismo Prawno-Historyczne” 2012, z. 1, s. 149-167.

${ }^{86}$ Der Reichsführer SS. Reichskommissar für die Festigung deutschen Volkstums. Berlin, am 9. Mai 1940. Anordnung 17/II; zob. F. Połomski, Rasistowskie przestanki hitlerowskiej polityki „zniemczania”, s. 170. 
stwierdzające ich obywatelstwo „do odwołania”, po uzyskaniu pisemnej zgody ze strony Wyższego Dowódcy SS i Policji.

Lepszą sytuację miały kobiety, gdyż nabywały obywatelstwo niemieckie w razie małżeństwa $\mathrm{z}$ Niemcem. Nie podlegały one przepisom o przymusowym zatrudnieniu, mogły zmienić miejsce zamieszkania bez zgody policji i rozwiązać stosunek pracy za wypowiedzeniem ${ }^{87}$. W Kraju Warty osoby nadające się do zniemczenia, ostatecznie od 1943 roku, musiały przymusowo nauczyć się posługiwania językiem niemieckim ${ }^{88}$.

Zasadnicza różnica między zniemczaniem a volkslistą polegała na tym, że pierwsze z nich konsekwentnie oparto na przesłankach rasowych, podczas gdy przy tym drugim sposobie germanizacji badania rasowe odgrywały rolę drugorzędną albo nawet w ogóle je pomijano, choć wyjątek stanowił tu Kraj Warty. Jak trafnie stwierdza F. Połomski:

przy germanizacji za pomocą Niemieckiej Listy Narodowej rolę odgrywały względy pragmatyczne, zapotrzebowanie na rekruta i siłę roboczą, a decydowały przesłanki tradycyjne, takie jak postawa wobec niemczyzny w okresie międzywojennym, przodkowie uznani za Niemców, stosunek do Niemców miejscowych czy kwalifikacje zawodowe. Badania rasowe, nawet tam, gdzie były przewidziane, miały znaczenie drugorzędne lub nie liczono się z nimi w ogóle. Na Pomorzu Gdańskim czy na Górnym Śląsku wielkorządcy i Gauleiterzy Albert Forster i Fritz Bracht pominęli badania rasowe, jako czynnik decydujący w wątpliwych przypadkach. Stanęli oni na stanowisku uznania za Niemców możliwie jak największej liczby Polaków, mając za sobą m.in. poważne argumenty natury gospodarczej. Za wyjątkiem Greisera, namiestnika Kraju Warty, wszyscy inni władcy polskich ziem przyłączonych do Rzeszy, Gauleiterzy Wagner i Bracht na Śląsku, Forster na Pomorzu czy E. Koch w Prusach Wschodnich, nie poddawali się naciskom Himmlera i odrzucili jego żądania oparcia Volkslisty na badaniach rasowych ${ }^{89}$.

Wprowadzenie niemieckiej listy narodowej na ziemiach wcielonych nastąpiło wraz z wejściem w życie dekretów z 8 i 12 października 1939 roku, to jest 26 października tegoż roku. Dla osób wpisanych na listę nie przewidziano automatycznego uzyskania obywatelstwa niemieckiego, a więc nadal nie miały one możliwość korzystania z pełni praw zawartych w części ogólnej i innych przepisach BGB. Centralną instytucją w zakresie decydowania o uzyskaniu obywatelstwa Rzeszy był Komisarz Rzeszy ds. Umacniania Niemczyzny, ustanowiony w dekrecie z 7 października 1939 roku. Funkcję tę pełnił Reichsführer SS Heinrich Himmler ${ }^{90}$.

Na podstawie okólnika Ministra Spraw Wewnętrznych Rzeszy z 25 listopada 1939 roku stwierdzenie przynależności do narodowości niemieckiej (volksdeutsch)

87 F. Połomski, Rasistowskie przesłanki hitlerowskiej polityki „zniemczania”, s. 178-181.

88 D. Majer, op. cit., s. 133 n.

89 F. Połomski, Rasistowskie przesłanki hitlerowskiej polityki ,zniemczania”, s. 168; zob. też K. Pospieszalski, Status prawny narodu polskiego na ziemiach zachodnich Rzeczypospolitej 19391945, s. $11 \mathrm{n}$.

90 Zob. M. Broszat, Der Staat Hitlers, München 1981, s. 395 n.; F. Połomski, Rasistowskie przesłanki hitlerowskiej polityki ,zniemczania”, s. 167 n. 
i nadawanie obywatelstwa niemieckiego należało do władz administracyjnych w okręgach Gdańsk - Prusy Zachodnie i Poznań (od 1940 roku Okręg Kraju Warty $)^{91}$. Obywatelstwo niemieckie mogli uzyskać byli obywatele gdańscy, polscy oraz bezpaństwowcy. Wraz z osobą uzyskującą obywatelstwo niemieckie mogli je także uzyskać żona lub mąż oraz dzieci do ukończenia 18 lat. Małżonkowie i dzieci uzyskiwali obywatelstwo nawet w wypadku nieprzynależenia do narodu niemieckiego, z wykluczeniem Żydów i ,innej podobnej obcej krwi”, jak Romowie $^{92}$.

Te dosyć mechaniczne zasady przyznawania niemieckiego obywatelstwa wkrótce poddał krytyce Himmler jako komisarz Rzeszy ds. umacniania niemczyzny. W rozporządzeniu z 12 września 1940 roku $^{93}$ postanowił on wprowadzić kryteria sprawdzania przydatności dla przyznania statusu Niemca. Oprócz próby badania kategorii ludności na ziemiach wcielonych i ich liczby (na przykład Kaszubi, Ślązacy) rozporządzenie po raz pierwszy wprowadzało podział ludności ziem wcielonych na grupy oparte na kryteriach ściśle politycznych. Podział oznaczono czterema literami. Grupa A obejmowała tych, którzy będąc niemieckiej narodowości, uzyskali już obywatelstwo niemieckie, a także podlegali niemieckiemu prawu o obywatelstwie. Grupa B obejmowała „wartościowych” Niemców, którzy będą mogli uzyskać obywatelstwo niemieckie po przejściu procedury „przywrócenia niemczyźnie”. Grupa C obejmowała ludzi obcej narodowości, jeżeli zostaliby uznani za wartościowych, a także niemieckich renegatów, których postawa przed 1 września 1939 roku nie była zgodna z pryncypiami Trzeciej Rzeszy (te osoby mogły otrzymać obywatelstwo niemieckie z możliwością jego odwołania). Wreszcie grupa D dotyczyła wszystkich pozostałych mieszkańców ziem wcielonych, którzy nie mieli żadnych związków z niemczyzną, jako przedstawicieli obcych narodowości. Do grupy I zaliczono tych Niemców (Volksdeutsch), którzy przed 1 września 1939 roku znani byli w Polsce z działalności proniemieckiej, będąc zwłaszcza członkami organizacji niemieckich. Grupa II także obejmowała osoby, które bez wątpliwości można było uważać za Niemców, ale które przed 1 września 1939 roku zachowywały się zupełnie biernie. Ich

91 MBliV, Jg. 1939, s. 2385 - Erwerb der deutschen Staatsangehörigkeit in den in das Deutsche Reich eingegliederten Ostgebieten. RdErl. D. RMdI. v. 25.11. 1939, - I e 5501/39-5000 Ost; tekst także K.M. Pospieszalski, Documenta Occupationis, t. 5, s. 108 n. Podstawą prawną jego wydania był dekret z 8 października 1939 r. o podziale i administracji terenów wschodnich, RGBl. I, Jg. 1939, s. 2042, Erlass des Führers und Reichskanzlers über die Gliederung und Verwaltung der Ostgebiete. Vom 8. Oktober 1939, tekst pol. [dekret Führera i kanclerza Rzeszy o podziale i administracji obszarów wschodnich z 8 października 1939 r.] zob. A. Konieczny, op. cit., s. 25; D. Majer, op. cit., s. 151.

92 Znaczną część okólnika tworzyły przepisy techniczne i proceduralne, w tym wzory kwestionariuszy osobowych.

93 Erlass für die Überprüfung und Aussonderung der Bevölkerung in den eingliederten Ostgebieten, Der Reichsführer SS Reichskommissar für die Festigung deutschen Volkstums I/K O 3b/28. 3. 40, Berlin 12. 9. 1940; cyt. za: K.M. Pospieszalski, Documenta Occupationis, t. 5, s. 114 n. 
niemczyzna musiała zostać zbadana i udowodniona. Grupa III obejmowała osoby spolszczone, które jednak można było przywrócić niemczyźnie. Dotyczyło to także polsko-niemieckich mieszańców i osób określanych jako Kaszubi, Ślązacy i Górnoślązacy. Ostatnia grupa, IV, obejmowała niemieckich renegatów popierających polszczyznę, a także prezentujących przed 1 września 1939 roku postawę wrogą wobec narodowego socjalizmu. Grupa I i II były uprzywilejowane, mogły uzyskiwać obywatelstwo niemieckie, choć tylko grupa I mogła ,z automatu” starać się o przyjęcie do NSDAP. Grupa III i IV „,musiała poprzez intensywną robotę wychowawczą w Starej Rzeszy wraz z upływem czasu zostać przekształcona w wartościowych Niemców”. W odniesieniu do IV grupy istniała wątpliwość, czy w ogóle warto było zadawać sobie trud przekonywania ich do niemczyzny i roboty wychowawczej dla zrozumienia przez nich ustroju Trzeciej Rzeszy. Stąd postulowano kolejny podział ludności na pięć grup. Grupa I i II miałaby szansę uzyskać obywatelstwo niemieckie, grupa III po działaniach wychowawczych, a ostatnia grupa IV teraz dzieliłaby się na dwie nowe; do pierwszej zaliczono by Niemców - renegatów, którzy podlegaliby ,intensywnej robocie wychowawczej” w obozie koncentracyjnym, a także uprzywilejowanych wartościowych dla zniemczenia Ukraińców, Rosjan, Białorusinów, Czechów i Litwinów. Ostatnia, V, grupa obejmowałaby pozostałe obce narodowo grupy nienadające się do zniemczenia.

Rozporządzenie to po raz pierwszy posługiwało się pojęciem wpisu na niemiecką listę narodową, a także regulowało możliwość wpisu na nią, zgodnie z podziałem ludności na cztery grupy, wprowadzając $\mathrm{w}$ związku $\mathrm{z}$ tą listą jeszcze dalszy podział ludności na cztery grupy, oznaczone tym razem numerami. Do grupy I zaliczono tych Niemców, którzy przed 1 września 1939 roku znani byli w Polsce z działalności proniemieckiej, będąc zwłaszcza członkami organizacji niemieckich. Grupa II także obejmowała osoby, które bez wątpliwości można było uważać za Niemców, ale którzy przed 1 września 1939 roku zachowywali się zupełnie biernie. Ich niemczyzna musiała zostać zbadana i udowodniona. Grupa III obejmowała osoby spolszczone, które jednak można było przywrócić niemczyźnie. Dotyczyło to także polsko-niemieckich mieszańców, a także osób określanych jako Kaszubi, Ślązacy i Górnoślązacy. Ostatnia grupa IV obejmowała niemieckich renegatów, popierających polszczyznę, a także wyrażających przed 1 września 1939 roku postawę wrogą wobec narodowego socjalizmu. Grupa I i II były uprzywilejowane, mogły uzyskiwać obywatelstwo niemieckie, choć tylko grupa I mogła „z automatu” starać się o przyjęcie do NSDAP. Grupa III i IV „musiała poprzez intensywną robotę wychowawczą w Starej Rzeszy wraz z upływem czasu zostać przekształcona w wartościowych Niemców”. W odniesieniu do IV grupy istniała wątpliwość, czy w ogóle warto było zadawać sobie trud przekonywania ich do niemczyzny i roboty wychowawczej dla zrozumienia przez nich ustroju Trzeciej Rzeszy. Stąd postulowano kolejny podział ludności na pięć grup. Grupa I i II miałaby szansę uzyskać obywatelstwo niemieckie, grupa III po działaniach wychowawczych, a ostatnia grupa IV teraz dzieliłaby się 
na dwie nowe, do której pierwszej zaliczono by Niemców — renegatów, którzy podlegaliby ,intensywnej robocie wychowawczej” w obozie koncentracyjnym, a także uprzywilejowanych wartościowych dla zniemczenia Ukraińców, Rosjan, Białorusinów, Czechów i Litwinów. Ostatnia piąta grupa obejmowałaby pozostałe obce narodowo grupy. Ostatnia piąta grupa obejmowałaby pozostałe obce narodowo grupy, nienadające się do zniemczenia.

Polacy mieli podlegać specjalnemu sprawdzeniu ich przydatności, ale procedury w tej kwestii Komisarz ds. Umocnienia Niemczyzny musiał dopiero opracować. Wprowadzono je okólnikiem z 14 listopada 1940 roku, wydanym przez Ministra Spraw Wewnętrznych ${ }^{94}$. Podział na jednoznaczne grupy Niemców i Polaków uznano z czasem za zbyt jednostronny i rozpoczęły się prace nad stworzeniem norm prawnych dla osób mieszanych narodowościowo, by wyodrębnić te, które miały „domieszkę krwi niemieckiej” o tyle istotną, że nadawały się one do ponownego zniemczenia. Ostateczny kształt został nadany tej polityce przepisami z lat 1940-1942. Pierwszym ważnym aktem prawnym, jest tutaj zarządzenie Reichsführera SS i komisarza Rzeszy ds. umacniania niemczyzny Heinricha Himmlera z 12 września 1940 roku $^{95}$, które zostało faktycznie zastąpione rozporządzeniem z 4 marca 1941 roku o niemieckiej liście narodowej oraz obywatelstwie niemieckim na włączonych do Rzeszy obszarach wschodnich ${ }^{96}$, znowelizowanym rozporządzeniem z 31 stycznia 1942 roku $^{97}$. Obywatelstwo niemieckie mogły uzyskać osoby, które przed 1 września 1939 roku posiadały obywatelstwo polskie lub gdańskie na obszarach wcielonych do Rzeszy Niemieckiej lub tam zamieszkiwały. Wyłączono możliwość nadania takiego obywatelstwa osobom będącym obywatelami polskimi lub gdańskimi, jeżeli zamieszkiwały one na terenie Generalnego Gubernatorstwa, chyba że przeniosły się tam po 1 grudnia 1939 roku, a ewentualnie uzyskały one do wejścia w życie tego rozporządzenia obce obywatelstwo lub były obywatelami gdańskimi, wpisanymi na I lub II volkslistę. Nowelizacja z 1942 roku dołączyła tu jeszcze tę grupę obywateli gdańskich, którzy przed 1 stycznia 1937 roku uzyskali miejsce pobytu poza ziemiami

94 MBliV, Jg. 1940, s. 2111 - Bescheinigungen über die Nichtzugehörigkeit zum polnischen Volke, RMdI Ie 5504 VIII-40 - 5000 Ost, RdErl. D. RMdI. Vom 14. November 1940; tekst także w K.M. Pospieszalski, Documenta Occupationis, t. 5, s. 118 n.

95 Erlass zur Überführung und Aussonderung der Bevölkerung in den eingegliederten Ostgebieten. Vom 12. September 1940 (zob. wyżej); D. Majer, op. cit., s. 152; F. Połomski, Rasistowskie przesłanki hitlerowskiej polityki ,zniemczania”, s. 168-169. Wymienia on wcześniejsze zarządzenie Himmlera z 9 maja 1940 r., oznaczone numerem 17/II.

96 RGB1. I, Jg. 1941, s. 118 - Verordnung über die Deutsche Volksliste und die deutsche Staatsangehörigkeit in den eingegliederten Ostgebieten. Vom 4. März 1941. Tekst polski zob. A. Konieczny, op. cit., s. 36 n.; por. też R. Kaczmarek, Niemiecka polityka narodowościowa na Górnym Śląsku (1939-1945), „Pamięć i Sprawiedliwość” 2004, nr 2 (6), s. 123 n.

97 RGB1. I, Jg. 1942, s. 51 - Zweite Verordnung über die Deutsche Volksliste und die deutsche Staatsangehörigkeit in den eingegliederten Ostgebieten. Vom 31. Januar 1942. Tekst jednolity w K.M. Pospieszalski, Documenta Occupationis, t. 5, s. 119 n. 
wcielonymi, na terenie Atreichu, lub przed 1 września 1939 roku osiedlili się na innym wcielonym obszarze (Marchia Wschodnia, Kraj Sudecki lub Okręg Kłajpedy) lub na obszarze Protektoratu Czech i Moraw albo zagranicą. Trzeba także zwrócić uwagę na $\S 4$ ust. 1, który wskazywał na możliwość odebrania do 31 grudnia 1941 roku przyznanego już obywatelstwa niemieckiego obywatelom gdańskim (zaliczonym do I lub II volkslisty). Nowelizacja z 1942 roku przedłużyła ten termin do 30 września tegoż roku. Dodała też ust. 2 wykluczający możliwość nadania w tym trybie obywatelstwa niemieckiego Żydom, Romom i mieszańcom żydowskim.

Stworzona w tych przepisach ,niemiecka lista narodowa” dzieliła osoby nią objęte na cztery grupy (4 listy $)^{98}$. Dwie pierwsze grupy stanowili przynależni do narodowości niemieckiej, którzy przed 1 września 1939 roku aktywnie działali jako Niemcy albo „swoją niemieckość obronili”. Osoby te uznano za obywateli niemieckich, stwierdzając, że obywatelstwo uzyskały już 26 października 1939 roku z chwilą wejścia w życie dekretu z 8 października 1939 roku. W zakresie trzeciej listy rozporządzenie z 1941 roku było enigmatyczne, w $\S 5$ stwierdzało, że „byli polscy lub gdańscy obywatele, którzy zostaną przyjęci do 3 oddziału Niemieckiej Listy Narodowej, nabywają obywatelstwo niemieckie w drodze nadania”. Było ono o tyle niejasne, że przesłanki zostały skonkretyzowane dopiero w zarządzeniu wykonawczym MSW z 13 marca 1941 roku, z którego wynikało, że decyzje w sprawach nadania tym osobom obywatelstwa niemieckiego Minister Spraw Wewnętrznych Rzeszy wyda w porozumieniu z kompetentnymi instytucjami „w polityce wobec obcych” (§ 10 zarządzenia z 13 marca 1941 roku), a z $\S 10$ rozporządzenia z 4 marca 1941 roku wynika, że przypisy wykonawcze w tych kwestiach miały być wydane w porozumieniu z zastępcą Führera i Reichsführerem SS jako Komisarzem Rzeszy ds. Umacniania Niemczyzny ${ }^{99}$. Zarządzenie stanowiło, że przede wszystkim należy uwzględniać przynależność do „krwi niemieckiej", a postępowanie powinno badać kryteria rasowe ${ }^{100}$. Przy nadaniu należącym do 1 grupy niemczyzna petenta nie powinna budzić żadnych wątpliwości. Odnośnie do 2 grupy dyskwalifikacyjną przesłanką był jakikolwiek pozytywny stosunek do polskości i uczestnictwo w polskich organizacjach. Za każdy razem uzyskanie obywatelstwa według 3 listy narodowej nie było automatyczne i musiało być indywidualnie nadane ${ }^{101}$.

98 Omówienie tych grup: F. Połomski, Rasistowskie przesłanki hitlerowskiej polityki ,,zniemczania”, s. 173 n.; A. Kilian, Przynależność państwowa do odwołania i jej konsekwencje jako element hitlerowskiej polityki asymilacyjnej, SnFiZH 11, 1987, s. 183-193.

99 Der Reichsminister des Innern, Berlin, den 13. März 1941, 1 e 5125/41 5000 Ost, Erwerb der deutschen Staatsangehörigkeit durch ehemalige polnische und Danziger Staatsangehörige; tekst w K.M. Pospieszalski, Documenta Occupationis, t. 5, s. 122 n.

100 Zob. też zarządzenie Komisarza Rzeszy z 30 września 1941 r. - Rassische Musterung der Angehörigen der Abteilung 3 der Deutschen Volksliste, Anordnung 50/I; K.M. Pospieszalski, Documenta Occupationis, t. 5, s. 144-145.

101 D. Majer, op. cit., s. 152. 
Zarządzenie z 1941 roku próbowało doprecyzować kryteria pozyskiwania dla niemczyzny członków 3 oddziału volkslisty. Miano zwracać uwagę na pochodzenie niemieckie, a co do mieszańców - czy ciążą oni ku niemczyźnie. Ponieważ osoby te mogły w domu nie posługiwać się językiem niemieckim, należało nadawać obywatelstwo niemieckie osobom z 3 oddziału ostrożnie ${ }^{102}$. W odniesieniu do 4 oddziału volkslisty należało być jeszcze bardziej ostrożnym, zwłaszcza że osoby te mogły wcześniej aktywnie działać w ruchu polskim. Inaczej należało natomiast patrzeć na 3 i 4 oddział volkslisty co do ich służby w Wehrmachcie ${ }^{103}$. Ostatnim aktem prawnym w tych kwestiach był dekret Führera z 19 maja 1943 $\mathrm{roku}^{104}$. Umożliwiał on przez służbę w wymienionych w tytule formacjach uzyskiwanie obywatelstwa niemieckiego ${ }^{105}$.

Nowelizacja z 1942 roku znacznie rozszerzyła $\S 5$. Ze znowelizowanego przepisu wynikało, że w wypadku obywateli gdańskich, których sytuację prawną - wspomnianą wcześniej — określono w tej samej noweli, konieczne było sprawdzenie przez kompetentne władze, czy spełniali oni kryteria konieczne do nadania obywatelstwa niemieckiego. Nowelizacja wprowadziła także możliwość odebrania obywatelstwa niemieckiego w ciągu 10 lat od jego nadania (co do konkretyzacji zasad odbierania obywatelstwa zob. zarządzenie Komisarza Rzeszy z 9 lutego 1942 roku $\left.^{106}\right)$.

Przy procedurze odwoławczej konieczne było uzyskanie stanowiska Reichsführera SS jako Komisarza Rzeszy ds. Umacniania Niemczyzny. O odebraniu obywatelstwa można było udzielać publicznych informacji.

Podobnie było z 4 listą narodową, której dotyczył $§ 6$ rozporządzenia z 4 marca 1941 roku:

1. Byli polscy lub gdańscy obywatele, którzy zostaną przyjęci do oddziału 4 Niemieckiej Listy Narodowej, nabywają w drodze nadania obywatelstwo niemieckie aż do odwołania.

102 Zob. też zarządzenie Komisarza Rzeszy z 10 lutego 1942 r.; K.M. Pospieszalski, Documenta Occupationis, t. 5, s. 145-146; a także Runderlass des Reichsministers des Innern betr. weitere Durchführungsvorschriften zur Verordnung über die Deutsche Volksliste; hier Eintragung verstorbener oder verschollener Personen. Vom 28. Juli 1943; K.M. Pospieszalski, Documenta Occupationis, t. 5, s. $148 \mathrm{n}$.

103 Reichssicherheitsamt IV D2 - 1218/41, Berlin den 12. Mai 1942, Betr. Deutschstämmige, die sich ihrer Wehrpflicht zu entziehen versuchen; tekst w K.M. Pospieszalski, Documenta Occupationis, t. 5, s. 147 n.; ponadto Oberkommando der Wehrmacht AZ.: 1 k20 36 AWA (BW Sied.)/AWA (J)/AHA/Ag./E/(Ia) Nr. 3358/42 Berlin, den 2. Oktober 1942, Betr. Behandlung der in Abt. 3 u. 4 der deutschen Volksliste eingetregenen Wehrpflichten und ihrer Angehörigen; tekst w K.M. Pospieszalski, Documenta Occupationis, t. 5, s. 161 n.

104 Erlass des Führers über den Erwerb der deutschen Staatsangehörigkeit durch Einstellung in die deutsche Wehrmacht, die Waffen-SS, die deutsche Polizei oder die Organisation Todt. Vom 19 Mai 1943, RGB1. I, Jg. 1943, s. 315; tekst także K.M. Pospieszalski, Documenta Occupationis, t. 5 , s. $172 \mathrm{n}$.

105 O służbie w Wehrmachcie zob. R. Kaczmarek, Polacy w Wehrmachcie, Kraków 2011.

106 Allgemeine Anordnung Nr. 12/C über die Behandlung der in die Deutsche Volksliste eingetragener Personen). Tekst zob. K.M. Pospieszalski, Documenta Occupationis, t. 5, s. 150 n. 
2. Obywatelstwo niemieckie aż do odwołania nabywają w drodze nadania także ci byli polscy lub gdańscy obywatele obcej przynależności narodowej, którzy zostaną specjalnie określeni na podstawie wytycznych Reichsführera SS, Komisarza Rzeszy do spraw Umacniania Niemczyzny.

3. Uzyskanie obywatelstwa niemieckiego może być odwołane tylko w ciągu 10 lat od chwili nabycia. Decyzje o odwołaniu wydaje Minister Spraw Wewnętrznych Rzeszy w porozumieniu z Reichsführerem SS, Komisarzem Rzeszy do spraw Umacniania Niemczyzny, lub inne określone przez nich władze. W przypadku odwołania utrata obywatelstwa niemieckiego następuje z chwilą doręczenia decyzji lub publicznego obwieszczenia.

Nowelizacja z 1942 roku dodawała jeszcze przepis mówiący, że Żydzi i Romowie nie mogli uzyskać nawet statusu ,przynależnych do państwa” w świetle $\S$ 5 pierwszego rozporządzenia wykonawczego do ustawy o obywatelstwie Rzeszy z 14 listopada $1935 \mathrm{roku}^{107}$. Z powodu niejasności dotyczących 4 oddziału volkslisty Reichsführer SS jako Komisarz Rzeszy ds. Umocnienia Niemczyzny zmuszony został 16 lutego 1942 roku do ogłoszenia zarządzenia dotyczącego kandydatów do zaliczenia do tej grupy ${ }^{108}$. Położono w nim nacisk na okoliczność, że przyznawanie obywatelstwa niemieckiego dla 4 oddziału niemieckiej listy narodowej zawsze następowało z możliwością jego odwołania. Reichsführer SS zwracał nakazywał szczególną ostrożność, gdyż do tej grupy zaliczali się niemieccy renegaci i ,spolonizowani Niemcy”. W obrębie omawianych tu kategorii dopatrywano się kilku grup. Pierwsza obejmowała mieszańców osób niemieckiego pochodzenia z osobami obcego pochodzenia, a druga - dzieci osób z grupy pierwszej. Trzecią grupę tworzyły osoby pozostające pod wpływem Kościoła katolickiego. Czwartą tworzyli wyznawcy Kościoła ewangelicko-augsburskiego, kierowanego przez biskupa Burschego. Piątą byli karierowicze, którzy zgłaszając się do niemczyzny, liczyli na poprawę ich położenia materialnego. Szósta grupa obejmowała osoby z wyższych warstw społecznych (szlachta, wielcy posiadacze ziemscy, duchowni), które z powodów koniunkturalnych podpisywały listę narodową. Wreszcie ostatnia grupa obejmowała Niemców, którzy wychowywali się w „czysto polskim otoczeniu”. Dla sprawdzania nadawania obywatelstwa niemieckiego w 1942 roku ustanowiono specjalny trybunał - Der Oberste Prüfungshof für Volkszugehörigkeitsfragen ${ }^{109}$.

107 Erste Verordnung zum Reichsbürgergesetz. Vom 14. November 1935, RGB1. I, Jg. 1935, s. 1333.

108 Zob. zarządzenie Komisarza Rzeszy z 16 lutego 1942 r. (VII/41-176-II A 2 Nr. 420, Behandlung der in der Abteilung 4 der Deutschen Volksliste eingetragenen Personen). Tekst zob. K.M. Pospieszalski, Documenta Occupationis, t. 5, s. 156 n.

109 Der Reichsminister des Innern, Berlin, den 30. Mai 1942, 1 Ost 768/42 4170, Verfahren und Zuständigkeit des Obersten Prüfungshofs für Volkszugehörigkeitsfragen in den eingliederten Ostgebieten. Tekst: K.M. Pospieszalski, Documenta Occupationis, t. 5, s. 140 n. 
Ostateczne narzucenie obywatelstwa niemieckiego Polakom i innym uprawnionym narodowościom zamieszkałym na ziemiach wcielonych nastąpiło przez wprowadzenie niemieckiej ustawy o nabywaniu obywatelstwa Rzeszy z 22 lipca 1913 roku, o czym rozstrzygnęło zarządzenie Ministra Spraw Wewnętrznych Rzeszy z 11 września 1941 roku, które powiązało jej przepisy z przepisami o niemieckiej liście narodowej ${ }^{110}$.

Kolejne rozporządzenie, z 25 kwietnia 1943 roku, o przynależności państwowej na odwołanie, wprowadzało pojęcie „obywatelstwa na odwołanie”, a ustalenie, kto miał mu podlegać, oddano Ministrowi Spraw Wewnętrznych Rzeszy w porozumieniu z Reichsführerem SS jako Komisarzem Rzeszy ds. Umacniania Niemczyzny ${ }^{111}$. Odwołanie obywatelstwa można było przeprowadzać tylko do upływu 10 lat od jego nadania. Nadanie czasowe dotyczyło też dzieci, zarówno małżeńskich, jak i pozamałżeńskich, danej osoby ${ }^{112}$.

O utracie obywatelstwa miano informować publicznie, podobnie jak o zrzeczeniu się obywatelstwa. Pierwsze rozporządzenie wykonawcze wskazywało na konieczność pozyskiwania dla Rzeszy Niemieckiej obywateli krajów okupowanych, którzy mieli cechy korzystne dla zniemczenia, w tym także dzieci nieślubne, porzucone itp. Pospieszalski obok tekstu rozporządzenia wykonawczego umieszcza stanowisko Der Oberste Prüfungshof für Volkszugehörigkeitsfragen z 3 stycznia 1944 roku w sprawie dokładniejszego określenia, kogo należałoby pozyskać dla zniemczenia. Wymieniono między innymi Górnoślązaków. W razie odebrania obywatelstwa jego utrata obejmowała zarówno żonę, jak i dzieci osoby, która utraciła obywatelstwo ${ }^{113}$.

Procedura, w której arbitralnie orzekano, kto „nadaje się do zniemczenia” lub „nadaje się do ponownego zniemczenia”, zależała od zupełnie niejasnych okoliczności. Trudno się temu dziwić, gdy jasne kryteria prawne zastąpiono rasowymi, kierując się motywacją rasowo-polityczną. Do zakończenia działań wojennych nie udało się ustalić obiektywnych kryteriów pochodzenia niemieckiego i w dalszym ciągu panował chaos pojęciowy ${ }^{114}$. Jeszcze w 1942 roku prezydent

110 MBliV, Jg. 1941, szp. 1645 - Einführung des Reichs- und Staatsangehörigkeitsges. v. 22. 7. 1913 in den eingegliederten Ostgebieten. RdErl. d. RMdI v. 11. 9. 1941 - I e 5350/41 Ost. Odrębne uregulowania dotyczyły byłych obywateli gdańskich, którzy mogli składać podania do 30 czerwca 1942 r., o ile spełniali kryteria ustalone przepisami o niemieckiej liście narodowej; MBliV, Jg. 1941, szp. 229 -, Erwerb der deutschen Staatsangehörigkeit durch ehemalige Danziger Staatsangehörige. RdErl. D. RMdI. v. 23. 12.1941-I Ost 1892/41-4160.

111 Verordnung über die Staatsangehörigkeit auf Widerruf. Vom 25. April 1943, RGB1. I, Jg. 1943, s. 269. Tekst także K.M. Pospieszalski, Documenta Occupationis, t. 5, s. 166 n. Szczegóły procedury odwoływania obywatelstwa znajdują się w § 4-8.

112 Rozwinięcie tej problematyki nastąpiło w pierwszym rozporządzeniu wykonawczym z 25 kwietnia 1943 r. — Erste Verordnung über die Schutzangehörigkeit des Deutschen Reichs. Vom 25. April 1943, RGB1. I, Jg. 1943, s. 271; tekst także K.M. Pospieszalski, Documenta Occupationis, t. 5 , s. $168 \mathrm{n}$.

113 Zob. K.M. Pospieszalski, Documenta Occupationis, t. 5, s. 168 n.

114 D. Majer, op. cit., s. 153. 
rejencji inowrocławskiej (Kraj Warty) uskarżał się, że nie mając jasnych kryteriów, nie potrafił jednoznacznie przyznawać przynależności do odpowiedniego oddziału niemieckiej listy narodowej. Odpowiedź, którą otrzymał, nie była zadowalająca. Stwierdzono mianowicie, że Urząd do Spraw Rasowych i Osiedleńczych SS twierdzi, iż procedura postępowania „była już od dłuższego czasu prowadzona" i ,powinna być uzgodniona z procedurą wpisywania na listę narodową" ${ }^{115}$. Nic $\mathrm{z}$ tego nie wynikało, bo żadnej procedury wyjściowej do odwzorowania nie było ${ }^{116}$. Wcześniej już minister poinformował, że nawet po nadaniu niemieckiej przynależności narodowej, jeżeli ktoś „,nie sprawdzi się”, może być z powrotem uznany za Polaka ${ }^{117}$. Wniosek (ust. 5) należało złożyć do landrata, prezydenta policji lub nadburmistrza. Mimo to warto zaznaczyć, że germanizacja według modelu niemieckiej listy narodowej przyniosła okupantowi do stycznia 1944 roku łącznie 2750000 dawnych obywateli polskich, podczas gdy zniemczanie tylko kilkadziesiąt tysięcy ${ }^{118}$.

W rezultacie około dwu trzecich mieszkańców ziem wcielonych nie uzyskało statusu „osób nadających się do zniemczenia”, a tym samym możliwość korzystania przez nich z praw podmiotowych prywatnych podlegała restrykcjom. Docelowo wszyscy oni mieli być wysiedleni po pokonaniu ZSRR na Syberię ${ }^{119}$.

\section{Zakazy dotyczące zawierania małżeństw. Prawo do macierzyństwa i ojcostwa}

Władze okupacyjne zamierzały ingerować w sprawy zawierania związków małżeńskich w sposób zupełny ${ }^{120}$. Nie było przy tym jednolitej praktyki w poszcze-

115 Ibidem, s. 154.

116 Pismo Ministra Spraw Wewnętrznych Rzeszy z 10 lipca 1942 r. - Schreiben des Reichsministers des Innern an Reichsminister der Justiz vom 10. Juli 1942; za: D. Majer, op. cit., s. 154.

117 MBliV, Jg. 1940, szp. 2111, Bescheinigungen über die Nichtzugehörigkeit zum polnischen Volke. RdErl. d. RMdI v. 14. 11. 1940 I e 5504 VIII-40-5000 Ost; zob. też D. Majer, op. cit., s. 154.

118 F. Połomski, Rasistowskie przesłanki hitlerowskiej polityki ,zniemczania”, s. 191.

119 K. Pospieszalski wyróżnia cztery fazy wysiedlania ludności polskiej z ziem wcielonych. Pierwsza trwała w 1939 r. i była dość chaotyczna, druga z wiosny 1940 r. była już lepiej zorganizowana. Ostatnie dwie z 1941 r. i lat następnych wiązały się z umieszczaniem Polaków w obozach przejściowych; zob. K. Pospieszalski, Status prawny narodu polskiego na ziemiach zachodnich Rzeczypospolitej 1939-1945, s. 15, 16.

${ }^{120}$ Co do prawa małżeńskiego w Trzeciej Rzeszy zob. L. Górnicki, T. Kruszewski, op. cit., s. $58 \mathrm{n}$. i tam podana literatura. Tuż przed wybuchem i w czasie drugiej wojny światowej w ustawodawstwie małżeńskim wprowadzano pewne ułatwienia, jak ceremonię ślubną o uproszczonej procedurze i przyspieszenie małżeństwa (RGB1. I, Nr. 154, S. 1540 - RGB1. I, Nr. 221, S. 2163 - Zweite Verordnung zur Ausführung des Personenstandsgesetzes. Vom 30. August 1939), ślub na odległość" (Ferntrauung) - Dritte Verordnung zur Ausführung des Personenstandsgesetzes (Personenstandsverordnung der Wehrmacht). Vom 4. November 1939 oraz: RGBI. I, Nr. 145, S. 1107 - Verordnung zur Änderung der Dritten Verordnung zur Ausführung des Personenstandsgesetzes. Vom 15. August 
gólnych jednostkach administracyjnych na ziemiach wcielonych. Najbardziej specyficzna polityka istniała w rejencji ciechanowskiej (Regierungsbezirk Zichenau), włączonej do Prus Wschodnich. Tutaj do 1942 roku wprowadzono z jednej strony całkowity zakaz zawierania małżeństw Niemców z nie-Niemcami, a z drugiej — zakaz zawierania związków małżeńskich między inną niż niemiecka ludnością w stosunkach wzajemnych. Podobne regulacje istniały w Kraju Warty, choć tutaj namiestnik Rzeszy Arthur Greiser nie zdecydował się na wprowadzenie całkowitego zakazu zawierania małżeństw. Polityka Greisera opierała się na tych samych założeniach, które realizowano w rejencji ciechanowskiej. Chodziło tu zahamowanie wzrostu liczby ludności „niższej rasowo”. Zakładano, że przy wprowadzonym zakazie zawierania małżeństw będzie utrudnione rodzenie dzieci. Pierwsze działania Greisera miały ściśle rasistowski charakter i wiązały się z wprowadzeniem zakazu zawierania małżeństw między Polakami i Żydami. W następnej kolejności zakazał on zawierania związków małżeńskich między Niemcami (reichs- i volksdeutschami) a Polakami. Nie udało mu się natomiast wprowadzenie całkowitego zakazu zawierania małżeństw między Polakami. Jedynie dla utrudnienia ich zawierania podniósł granice wiekowe wstąpienia w związek małżeński: do 25 lat dla Polek i do 28 lat dla Polaków ${ }^{121}$.

Zarządzenie Ministra Sprawiedliwości z 2 kwietnia 1942 roku wprowadzało natomiast zakaz zawierania małżeństw między Niemcami i członkami grupy 3 volkslisty, o której dalej, na ziemiach wcielonych. Wszelkie takie związki małżeńskie były niedopuszczalne, wyjątki dopuszczono tylko za zgodą szefa sztabu Reichsführera SS jako Komisarza Rzeszy ds. Umacniania Niemczyzny (pkt 7 zarządzenia) ${ }^{122}$. Natomiast dozwolone było zawieranie małżeństw z osobami „krwi pokrewnej”, o ile utrzymywały „czystość rasową" ${ }^{23}$.

Na ziemiach wcielonych praktyka rozdzielania Polaków od Niemców wynikała z zarządzeń administracyjnych, wobec braku jasnych rozwiązań ustawowych. Pamiętać też trzeba, że na tych ziemiach urzędy stanu cywilnego odmawiały zarejestrowania polsko-niemieckich małżeństw ${ }^{124}$. Działania te spotkały

1940 i RGB1. I, Nr. 106, s. 595 - Vierte Verordnung zur Änderung der Personenstandsverordnung der Wehrmacht. Vom 17. Oktober 1942, a także RGBI. I, Nr. 46, s. 219 - Vierte Verordnung zur Ausführung und Ergänzung des Personenstandsgesetzes. Vom 27. September 1944, czy ślub post mortem [Nachträgliche (postmortale) Eheschliessung] oraz możliwość rozwodu po śmierci (RGBI. I, s. 145 - Fünften Durchführungsverordnung zum Ehegesetz vom 18. März 1943. Ułatwienia te nie dotyczyły jednak obywateli polskich na ziemiach wcielonych, chyba że chodziło o Polaków członków niemieckiego Wehrmachtu czy jednostek zbrojnych SS, a ewentualnie Deutsche Reichsbahn; zob. Deutsches Eherecht im Zweiten Weltkrieg, https://de.wikipedia.org/wiki/Deutsches_Eherecht_im_Zweiten_Weltkrieg.

$\overline{121}$ D. Majer, op. cit., s. 156.

122 Nr. 151 Behandlung der in die Deutsche Volksliste eingetragener Personen, AV v. RJM v. 2. 4.1942 (1101 - Sdb - V. a 7 316, Deutsche Justiz, Jg. 1942, s. 259).

123 F. Ryszka, op. cit., s. 448.

124 D. Majer, op. cit., s. 71. 
się z poparciem Reichsführera SS jako Komisarza Rzeszy ds. Umocnienia Niemczyzny. Były one jego zdaniem poprawne, ale — jak sądził — powinny być usankcjonowania prawnie. Najbardziej radykalne działania w tej dziedzinie, jakie prowadził Greiser, niespodziewanie spotkały się z krytyką ze strony Ministerstwa Spraw Wewnętrznych Rzeszy, co oznaczało, że namiestnik Kraju Warty coraz bardziej tracił wpływy w tym ministerstwie, które nie zamierzało popierać jego samowoli. Na konferencji w tymże ministerstwie, 21 stycznia $1943 \mathrm{roku}$, ostatecznie poparto stanowisko zajmowane przez Himmlera i zalecono przy tym, by na pozostałych obszarach wcielonych kierować się wzorami z Kraju Warty. Prawne uregulowanie nastąpiło kilka miesięcy po konferencji, na mocy rozporządzenia o „obywatelstwie ochronnym Rzeszy Niemieckiej” z 25 kwietnia 1943 roku, zwanego rozporządzeniem o poddaństwie ${ }^{125}$.

Wspomniane rozporządzenie o poddaństwie z 25 kwietnia 1943 roku było zwieńczeniem dotychczasowych działań władz okupacyjnych ${ }^{126}$. Szczególnie istotny był $\S 8$, zakazujący zawierania związków małżeńskich między osobami posiadającymi obywatelstwo niemieckie i tak zwanymi poddanymi (Schutzangehörige). Postanowienia te nie odnosiły się do osób uznanych za wartościowe rasowo i przeznaczonych do zniemczenia. W stosunku do Schutzangehörige oraz bezpaństwowców jedynie w drodze wyjątku dopuszczalne było udzielenie zezwolenia na małżeństwo i odstąpienie od obowiązujących zakazów. Osobę, która otrzymała obywatelstwo na próbę, obowiązywał zakaz zawierania związków małżeńskich z osobą, która nie uzyskała takiego obywatelstwa. Zakaz ten jednak w określonych okolicznościach mógł zostać uchylony. O uchyleniu zakazu decydował urząd stanu cywilnego, właściwy miejscowo, w porozumieniu z organem podległym Reichsführerowi SS jako Komisarzowi Rzeszy ds. Umacniania Niemczyzny.

Przepisy wykonawcze do tego rozporządzenia, sukcesywnie wydawane przez Reichsführera SS jako Komisarza Rzeszy ds. Umocnienia Niemczyzny, zmierzały do wprowadzenia całkowitego zakazu zawierania małżeństw między Polkami i Polakami na obszarach wcielonych. Najpierw została podniesiona granica wieku do zawierania małżeństw - wzorem Kraju Warty — do 25 lat dla Polek i do 28 lat dla Polaków, co nastąpiło na mocy zarządzania Himmlera z 10 stycznia 1944 roku $^{127}$. Następnie wytycznymi z 22 września tegoż roku zakazano lub przynajmniej istotnie ograniczono zawieranie małżeństw między osobami należącymi do ludności

125 RGB1. I, Jg. 1943, s. 271 - Erste Verordnung über die Schutzangehörigkeit des Deutschen Reichs. Vom 25. April 1943; potoczny tytuł: Verordnung über Schutzgehörigkeit. Tekst pierwszego rozporządzenia wykonawczego, tak zwanego rozporządzenia o poddaństwie z 25 kwietnia 1943 r., podaje także K.M. Pospieszalski, Documenta Occupationis, t. 5, s. 168 n.; zob. też D. Majer, op. cit., s. 71.

126 F. Połomski, Ograniczenia w zawieraniu małżeństw Niemców z cudzoziemcami w czasie II wojny światowej, „Studia Śląskie” 32, 1977, s. 355-357; D. Majer, op. cit., s. 156, 157.

127 MBliV, Jg. 1944, szp. 54, Eheschließliesungen von Schutzangehörigen polnischer Volkstums. RdErl. d. RMdI. v. 10. 1. 1944 - I Sta R 5545 IV/43 - 4028; zob. D. Majer, op. cit., s. 156, 157. 
polskiej $^{128}$. Przepisy te, ogłoszone pod koniec wojny, nie zostały już w pełni wcielone w życie. Ich skuteczność z powodu stale wzrastającej liczby urodzeń dzieci pozamałżeńskich na ziemiach wcielonych pozostawiała wiele do życzenia.

Od samego początku najdalej idącym ograniczeniom praw podlegali Żydzi, traktowani przez ideologię i propagandę hitlerowską jako przyczyna wszelkiego zła w świecie. Głównie w nich wymierzone były ustawy urzędnicze ${ }^{129}$, ale

128 Richtlinien des Chefs des Rasse- und Siedlugsamtes SS vom 22. September 1944 zu dem Erlass des Reichsministers des Innern und des Reichskommissars für Festigung des Deutschen Volkstums vom 10. 1. 1944; zob. D. Majer, op. cit., s. 157.

129 W zakresie dostępu do stanowisk zawodowych urzędników dość szybko po Machtergreifung doszło do ogłoszenia ustawy o odnowieniu stanu zawodowych urzędników (RGB1. I, Jg. 1933, s. 175 - Gesetz zur Wiederherstellung des Berufsbeamtentums. Vom 7. April 1933; zob. M. Broszat, op. cit., s. 301 n.; F. Celnikier, op. cit., s. 218 n.). Oprócz uregulowań nakazujących urzędnikom służenie narodowosocjalistycznemu państwu pojawił się słynny $\S 3$ - ,paragraf aryjski” (D. Majer, op. cit., s. 61 n.; K. Jonca, Polityka narodowościowa ..., s. 262 n.). Paragraf ten usuwał ze służby urzędników pochodzenia niearyjskiego. Mieli być oni przeniesieni w stan spoczynku lub - co do urzędników honorowych — przez rozwiązanie z nimi stosunku pracy. Ten wyłom w zasadzie równości wobec prawa zawierał jeszcze specyficzny wyjątek odnośnie do urzędników zatrudnionych do 1 sierpnia 1914 r., którzy walczyli w pierwszej wojnie światowej po stronie państw centralnych albo których ojcowie lub synowie polegli (RGBl. I, Jg. 1933, s. 245 - Dritte Verordnung zur Durchführung des Gesetzes zur Wiederherstellung des Berufsbeamtentums. Vom 26. Mai 1933, uwaga $\mathrm{nr} 3$ do § 3). Inną furtką było upoważnienie ministrów Rzeszy (MSW w porozumieniu z innymi ministrami) do wprowadzenia dalszych wyjątków. Zwolnienia mogli spodziewać się także urzędnicy (\$ 4), których dotychczasowa działalność polityczna nie gwarantowała, że będą służyć państwu narodowemu (zob. także RGBl. I, Jg. 1933, s. 233 - Zweite Verordnung zur Durchführung des Gesetzes zur Wiederherstellung des Berufsbeamtentums. Vom 4. Mai 1933, § 4 - bezterminowe zwolnienie urzędników, którzy nie gwarantują wykonywania poleceń państwa narodowego). Kolejna zmiana ustawy z 20 lipca 1933 r. usuwała wszystkich urzędników, którzy byli członkami partii komunistycznej i jej formacji (RGB1. I, Jg. 1933, s. 518 - Gesetz zur Ergänzung des Gesetzes zur Wiederherstellung des Berufsbeamtentums. Vom 20. Juli 1933; por. także RGB1. I, Jg. 1933, s. 458 — Verordnung zur Ergänzung der Zweiten Verordnung zur Durchführung des Gesetzes zur Wiederherstellung des Berufsbeamtentums. Vom 7. Juli 1933. RGBl. I, Jg. 1933, s. 678 - Zweite Verordnung zur Änderung und Ergänzung der Zweiten Verordnung zur Durchführung des Gesetzes zur Wiederherstellung des Berufsbeamtentums. Vom 28. September 1933). Ustawa ta, co było typowe dla Trzeciej Rzeszy, miała wskazany krótki termin obowiązywania (30 września 1933 r.), ale w rzeczywistości funkcjonowała do $1945 \mathrm{r}$. Ustawa istotnie podważała prawa podmiotowe jednostki, bo nie przewidywała żadnych form prawnych odwoławczych od decyzji o zwolnieniu ze służby. Jak objaśnił Hermann Göring jako premier rządu pruskiego: „wyeliminowanie urzędników pochodzenia niearyjskiego" było bezwzględnie konieczne „w interesie zachowania czystości rasy aryjskiej” (D. Majer, op. cit., s. 62). Ustawa była konsekwentnie wcielana w życie, najpierw w sferach urzędników wymiaru sprawiedliwości i innych związanych z władzami administracyjnymi, uznanymi za szczególnie istotne dla umocnienia Trzeciej Rzeszy (RGBl. I, Jg. 1933, s. 245 - Dritte Verordnung zur Durchführung des Gesetzes zur Wiederherstellung des Berufsbeamtentums. Vom 26. Mai 1933; uwaga nr 7 do § 3; zob. D. Majer, op. cit., s. 62-63. Zdarzały się jednak sytuacje krycia urzędników w niektórych ministerstwach, co czynniki oficjalne starały się zwalczać (ibidem, s. 63-64). Przepisy te dotyczyły także nauczycieli i zezwalały na usunięcie ich ze szkół, jeżeli byli oni ,niearyjczykami”. Ustawa utrudniała także przyjmowanie Żydów do szkół, by nie naruszać proporcji Żydów do Niemców w społeczeństwie. Usuwano uczonych żydowskich z wyższych uczelni (K. Jonca, 
ingerowały one również w zdolność do czynności prawnych osób „aryjskiego pochodzenia", wprowadzając w stosunku do nich ograniczenia co do zawierania małżeństw. Ustawa o ochronie niemieckiej krwi i niemieckiej czci miała na celu biologiczne rozwiązanie problemu żydowskiego przez zakaz zawierania

Polityka narodowościowa..., s. 263-264). Na mocy Reichshabilitationsordnung. Vom 13. Dezember 1934 ogłoszono, że habilitant musi mieć ,ppochodzenie aryjskie” (B. Blau, Das Ausnahmerecht für die Juden in Deutschland 1933-1945, Düsseldorf 1965, nr 61). Pierwsze rozporządzenie wykonawcze do ustawy o odnowieniu kadry urzędniczej z 11 kwietnia 1933 r. zawierało też po raz pierwszy w prawie Trzeciej Rzeszy definicję Żyda, zakładając, że Żydem była już osoba, której jedno z rodziców lub dziadków było tego pochodzenia (RGBl. I, Jg. 1933, s. 195 - Erste Verordnung zur Durchführung des Gesetzes zur Wiederherstellung des Berufsbeamtentums. Vom 11. April 1933). Doprecyzowanie nastąpiło w trzecim rozporządzeniu wykonawczym z 26 maja 1933 r. (RGB1. I, Jg. 1933, s. 245 - Dritte Verordnung zur Durchführung des Gesetzes zur Wiederherstellung des Berufsbeamtentums. Vom 26. Mai 1933; zob. F. Celnikier, op. cit., s. 218-221). Kolejnym aktem prawnym definiującym Żydów była ustawa z 21 maja 1933 r. (RGBl. I, Jg. 1933, s. 433 - Gesetz zur Änderung von Vorschriften auf dem Gebiete des allgemeinen Beamten-, des Besoldungs- und des Versorgungsrechts. Vom 30. Juni 1933; zob. F. Celnikier, op. cit., s. 221). Ostateczne regulacje prawne dotyczące urzędników zawarto w ustawie z 26 stycznia 1937 r. o służbie cywilnej (RGBl. I, Jg. 1937, s. 39 n. - Deutsches Beamtengesetz. Vom 26. Januar 1937; zob. F. Połomski, Ustawodawstwo rasistowskie..., s. 207 n.). Została ona ogłoszona, gdy obowiązywało już ustawodawstwo rasistowskie z 1935 r. Ustawa dopuszczała do służby urzędniczej tylko „osoby krwi niemieckiej lub pokrewnej”. Władze zwierzchnie danego urzędnika w porozumieniu z Ministerstwem Spraw Wewnętrznych miały obowiązek przenieść urzędników niearyjskich — zgodnie z ustawami norymberskimi chodziło o Żydów i mieszańców żydowskich I stopnia, choć w rzeczywistości usuwano także pozostałych mieszańców żydowskich, bowiem ustawa zmieniająca przepisy o urzędnikach z 30 lipca 1933 r. (RGBl. I, Jg. 1933, s. 433 - Gesetz zur Änderung von Vorschriften auf dem Gebiete des allgemeinen Beamten-, des Besoldungs- und des Versorgungsrechts. Vom 30. Juni 1933) przenosiła w stan spoczynku nawet osoby będące Żydami w jednej czwartej (zob. dodany ustawą § 1a do Reichsbeamtengesetz. Vom 31. März 1873, RGB1., Jg. 1873, s. 61; D. Majer, op. cit., s. 67). Kwestie te uregulowano nowelach do ustawy z 23 lipca 1933 r. (RGBl. I, Jg. 1933, s. 389 - Gesetz zur Änderung des Gesetzes zur Wiederherstellung des Berufsbeamtentums. Vom 23. Juli 1933, kolejnej: z 22 września 1933 r., RGBl. I, Jg. 1933, s. 655 — Dritte Gesetz zur Änderung des Gesetzes zur Wiederherstellung des Berufsbeamtentums. Vom 22. September 1933, oraz w czwartym rozporządzeniu wykonawczym z 18 lipca 1933 r., RGB1. I, Jg. 1933, s. 515 — Vierte Verordnung zur Durchführung des Gesetzes zur Wiederherstellung des Berufsbeamtentums. Vom 18. Juli 1933, a także w piątym rozporządzeniu wykonawczym z 29 września 1933 r., RGB1. I, Jg. 1933, s. 697 - Fünfte Verordnung zur Durchführung des Gesetzes zur Wiederherstellung des Berufsbeamtentums. Vom 29. September 1933). Zgodnie z § 25 ustawy z 1937 roku urzędnikiem mogła być tylko osoba krwi niemieckiej lub pokrewnej. Ta sama reguła dotyczyła jego małżonka. Na równi traktowano mieszańców żydowskich I stopnia. Gdy małżonkiem kandydata na urzędnika był mieszaniec żydowski II stopnia, decydowały władze zwierzchnie. Stosownie do § 59, gdy urzędnik już zatrudniony nie miał krwi niemieckiej lub pokrewnej, podlegał zwolnieniu ze służby, także gdy jego małżonek był mieszańcem I stopnia. Gdy urzędnik stanu wolnego chciał wstąpić związek małżeński z mieszańcem żydowskim II stopnia, musiał uzyskać zezwolenie. Natomiast nie wydano przepisów, które urzędowo traktowałyby gorzej urzędników o poglądach politycznych niezgodnych z pryncypiami Trzeciej Rzeszy (D. Majer, op. cit., s. 64-65). Byli oni usuwani na podstawie przepisów o odpowiedzialności dyscyplinarnej - Kodeks Dyscyplinarny Rzeszy z 26 stycznia 1937 roku (RGBl. I, Jg. 1937, s. 71 - Reichsdienststrafordnung (RDStO). Vom 26. Januar 1937; D. Majer, op. cit., s. 71; 
małżeństw między osobami „krwi niemieckiej lub rodzajowo zbliżonej” a Żydami, a także zakaz utrzymywania stosunków pozamałżeńskich z Żydami, stanowiący odtąd przestępstwo ,zhańbienia rasy” (Rassenschande) $)^{130}$. Ustanowiono także zakaz zatrudniania przez Żydów kobiet „krwi niemieckiej lub rodzajowo zbliżonej" jako służby domowej ${ }^{131}$. Szczegółowe zagadnienia sprecyzowane zostały w aktach wykonawczych ${ }^{132}$.

Zdaniem kierownictwa politycznego Trzeciej Rzeszy realizacja omawianych zamierzeń postępowała zbyt wolno nie tylko w Altreichu, lecz także na ziemiach wcielonych do Rzeszy w czasie wojny, co wynikało z niechęci do rozwodzenia się przez małżeństwa „Aryjczyków” z „nie-Aryjczykami”. Okazało się, że indoktrynacja nazistowska nie szła tak daleko, by małżonkowie zamierzali biernie poddawać się przepisom ustawy. Dlatego szukano innego środka prawnego, aby aktem administracyjnym rozwiązać wszystkie mieszane małżeństwa niemiecko-żydowskie ${ }^{133}$.

Własne regulacje dotyczące zakazu małżeństw członków NSDAP z osobami „narodowoobcymi” wydawało kierownictwo partyjne w Monachium, a ściślej zastępca Führera. Wymagane było w takich sytuacjach, zgodnie z zarządzeniem z 16 lutego 1938 roku, zezwolenie kierownika Partei-Kanzlei. Jednak już wydane w czasie wojny zarządzenie A 10/40 z 23 października 1940 roku uznawało te małżeństwa mieszane za w ogóle niepożądane, bo prowadziły do obniżenia poziomu rasowego. W odniesieniu do formacji SS wymagana był zgoda Himmlera (rozkaz z 31 grudnia 1931 roku), oparta wyłącznie na kryteriach rasy i zdrowotności dziedzicznej ${ }^{134}$. Odrębne przepisy dotyczyły również żołnierzy, ale Naczelne Dowództwo Sił Zbrojnych wydało je dopiero w 1943 roku. Początkowo

MBliV, Jg. 1943, szp. 1627, Eheschließung von Beamten, RdErl. d. RMdI. v. 28. 9. 1943 - III a 950 II/43 - 6101, auf Grund des Erlasses des Führers zur personalrechtlichen Vereinfachung v. 9. 3. 42 (RGBl. I, s. 120), wydany na podstawie Erlass des Führers zur personalrechtlichen Vereinfachung. Vom 9. März 1942, RGBl. I, Jg. 1942, s. 120). Urzędnik nie mógł nawet ożenić się z kobietą, która była wcześniej żoną Żyda MBliV, Jg.1943, szp. 1627, Eheschließung von Beamten, RdErl. d. RMdI. v. 28. 9. 1943 - III a 950 II/43 - 6101, auf Grund des Erlasses des Führers zur personalrechtlichen Vereinfachung v. 9. 3.42 (RGB1. I, s. 120), wydany na podstawie Erlass des Führers zur personalrechtlichen Vereinfachung. Vom 9. März 1942, RGB1. I, Jg. 1942, s. 120). Z kolei na mocy ustawy o służbie wojskowej z 21 maja 1935 r. Żydzi nie mogli jej pełnić (RGBl. I, Jg. 1935, s. 609 - Wehrgesetz. Vom 21. Mai 1935, § 15).

130 Ustawy norymberskie wprowadzały zakaz utrzymywania jakichkolwiek kontaktów cielesnych osób „krwi niemieckiej lub pokrewnej” z Żydami, ale także z żydowskimi mieszańcami i Romami, formułując pojęcie „zhańbienia rasy” (Rassenschande).

131 Wykluczono, by Żydzi mogli zatrudniać w gospodarstwie domowym osoby o aryjskim pochodzeniu, jeżeli nie miały ukończonych 45 lat; RGBl I, Jg. 1935, s. 1333 - Erste Verordnung zum Reichsbürgergesetz. Vom 14. November 1935; F. Połomski, Ustawodawstwo rasistowskie..., s. $143 \mathrm{n}$.

132 F. Połomski, Ustawodawstwo rasistowskie..., s. 106 n., 218 n.; L. Górnicki, T. Kruszewski, op. cit., s. 50.

133 Więcej L. Górnicki, T. Kruszewski, op. cit., s. 65.

134 Obszernie o tym F. Połomski, Ograniczenia w zawieraniu mał̇eństw..., s. 346-349. 
zastosowanie miał $\S 13$ ustawy małżeńskiej z 1938 roku, zgodnie z którym żołnierz, członek Arbeitsdienstu i urzędnik musieli przed zawarciem małżeństwa przedłożyć zezwolenie swojego zwierzchnika. Dopiero specjalne zarządzenie o małżeństwach członków Wehrmachtu zawieranych w czasie wojny z 28 stycznia 1943 roku wprowadziło generalny zakaz małżeństw z cudzoziemcami ${ }^{135}$.

W odniesieniu do Polaków w trakcie drugiej wojny światowej naruszane było również naturalne prawo do macierzyństwa i ojcostwa, gwarantowane ustawodawstwem wszystkich ówczesnych państw cywilizowanych. Szczególną rolę odegrała tu istniejąca od 1935 roku organizacja Lebensborn („Źródło Życia”) ${ }^{136}$.

\section{Ustawodawstwo sterylizacyjne i eutanazja}

Zarządzeniem Ministra Spraw Wewnętrznych Rzeszy z 13 stycznia 1941 roku rozciągnięto na ziemie wcielone ustawę sterylizacyjną z 1933 roku $^{137}$. Na jego mocy byli obywatele polscy, o ile nie mieli obywatelstwa radzieckiego lub innego, podlegali ubezpłodnieniu w razie spełniania kryteriów ustawy sterylizacyjnej ${ }^{138}$. Ustawę sterylizacyjną stosowano wobec Polaków w Niemczech od samego początku, a polityka ta była kontynuowana w stosunku do nich podczas drugiej wojny światowej, kiedy to podjęto próbę masowej sterylizacji „niższych ras” za pomocą promieni rentgena, czym zainteresowany był zwłaszcza Himmler, poszukujący skutecznych instrumentów w walce z rozrodczością Słowian ${ }^{139}$.

135 Więcej ibidem, s. 349-353.

136 Więcej L. Górnicki, T. Kruszewski, op. cit., s. 65-66 i tam podana literatura.

137 RGB1. I, Jg. 1933, s. 529 — Gesetz zur Verhütung erbkranken Nachwuchses. Vom 14. Juli 1933. Przekładu ustawy o ochronie przed dziedzicznie chorym potomstwem z 14 lipca 1933 r., zwanej ustawą sterylizacyjną, na język polski dokonał I. Świrski (Zagadnienie sterylizacji, Włocławek 1934, s. 3-5). Kopią tej ustawy był odpowiedni dokument obowiązujący na terenie Wolnego Miasta Gdańska z 14 listopada 1933 r. Na podstawie ustawy sterylizacyjnej stosowano przymus fizyczny w stosunku do osób, u których rozpoznana została dziedziczna choroba, ciężkie kalectwo fizyczne bądź zaawansowany alkoholizm; więcej L. Górnicki, T. Kruszewski, op. cit., s. 56-58 i tam podana literatura.

138 MBliV, Jg. 1941, szp. 115 - Behandlung von Ausländer bei der Durchführung des Gesetzes zur Verhütung erbkranken Nachwuchses. RdErl. D. RMdI. V. 13. 1. 1941 -IV b 3611/40-1079 e. $\mathrm{Na}$ mocy zarządzenia z 12 maja 1941 r. należało sporządzać dla MSW raporty o wykonywaniu ubezpłodnień na ziemiach wcielonych; zob. MBliV, Jg. 1941, szp. 927. Behandlung von Ausländer der Vordrucke zum Bericht über die Durchführung des Ges. zur Verhütung erbkranken Nachwuchses. RdErl. D. RMdI. V. 12. 5. 1941 -IV b 814/41-1079.

139 F. Połomski, Spór o stosowanie hitlerowskiego ustawodawstwa sterylizacyjnego do Polaków na terenie Opolszczyzny, „Studia Śląskie. Seria nowa” 3, 1960, s. 173-196; C. Madajczyk, Faszyzm i okupacje 1938-1945. Wykonywanie okupacji przez państwa Osi w Europie, t. 2. Mechanizmy realizowania okupacji, Poznań 1984, s. 200 n.; T. Cyprian, J. Sawicki, Ludzie i sprawy Norymbergi, Poznań 1967, s. 235 n.; S. Kłodziński, Z zagadnień ludobójstwa. Sterylizacja i kastracja promieniami Roentgena w obozie oświęcimskim. Dr Horst Schumann, „Przegląd Lekarski” 1964, nr 1, s. 105-111; A. Pankowicz, KL Auschwitz w procesach norymberskich (1945-1949), „Zeszyty 
Piąte rozporządzenie wykonawcze do ustawy o ochronie przed dziedzicznie chorym potomstwem z 25 lutego 1936 roku w art. 1 zawierało regulację przewidującą, że ubezpłodnienie kobiet należało przeprowadzać do ukończenia przez nie 38 roku życia ${ }^{140}$. Po przyjęciu Żyda dotkniętego chorobą psychiczną do lecznictwa zamkniętego od grudnia 1940 roku w żadnej sytuacji nie było dozwolone przetrzymanie go razem z chorym psychicznie „Aryjczykiem”" ${ }^{41}$. Trzeba przy tym wskazać na obowiązek donoszenia odpowiednim instancjom urzędowym o osobach podlegających ubezpłodnieniu na podstawie ustawy sterylizacyjnej ${ }^{142}$. Zarządzenie Ministra Spraw Wewnętrznych Rzeszy z 19 marca 1942 roku wykluczało tu możliwość samodzielnego składania wniosków o ubezpłodnienie przez Żydów ${ }^{143}$. Zarządzenie z 4 maja 1942 roku nakazywało sporządzać dokładne meldunki o liczbie dokonanych ubezpłodnieńn ${ }^{144}$. W 1942 roku Minister Spraw Wewnętrznych Rzeszy wskazał na niepokojące go praktyki opóźniania dokonania ubezpłodnienia albo co gorsza odsyłania bez dokonania tego zabiegu, w związku z tym ostrzegł, by w przyszłości takie praktyki zostały ukrócone ${ }^{145}$. W praktyce decydujące znaczenie w funkcjonowaniu tego systemu miała administracja państwowa ${ }^{146}$.

Oświęcimskie" 1983, nr 18, s. 277; R. Manvell, H. Fraenkel, Himmler, Warszawa 1971, s. 186 n.; F. Połomski, Rasizm w teorii i praktyce Trzeciej Rzeszy, SnFiZH 3, 1977 s. 129; L. Górnicki, T. Kruszewski, op. cit., s. 58.

140 RGBl. I, Jg. 1936, s. 122 — Fünfte Verordnung zur Ausführung des Gesetzes zur Verhütung erbkranken Nachwuchses.

141 MBliV, Jg. 1940, szp. 2261 - Aufnahme jüdischer Geistekranker in Heil- und Pflegeanstalten. RdErl. d. RMdI. v. 12. 12.1940-IV g 7123/40-5106, ust. 1.

142 Obowiązek taki wprowadzał art. 3 pkt b pierwszego rozporządzenia wykonawczego z 5 grudnia 1933 r. do ustawy sterylizacyjnej (Verordnung zur Verhütung erbkranken Nachwuchses. Vom 5. Dezember 1933), RGB1. I, Jg. 1933, s. 1021.

143 MBliV, Jg. 1942, szp. 605 - Durchführung des Ehegesundheitsgesetzes und des Gesetzes zur Verhütung erbkranken Nachwuchses gegenüber Juden. RdErl. D. RMdI. V. 19. 3. $1942-I V$ b 398/42-1075 a.

144 MBliV, Jg. 1942, szp. 997 — Vereinfachung bei der Durchführung des Ges. zur Verhütung erbkranken Nachwuchses und des Ehegesundheitsges. RdErl. D. RMdI. V. 4. 5. 1942 - IV b 516/ 42-1079.

145 MBliV, Jg. 1942, szp. 1297 - Durchführung des Art. 1 der Ersten VO. des Ges. zur Verhütung erbkranken Nachwuchses. RdErl. D. RMdI. V. 10. 6. 1942 - IV b 823 II/42 - 1079; zob. też ponowienie: MBLiV, Jg. 1942, szp. 1471, Vereinfachung der Verw.; hier: Verrechung bzw. Erstattung der für erbpflegerische Maßnahmen aufgewendeten Mittel. RdErl. D. RMdI. V. 10. 7. 1942 -IV b 918-42-1079 - Mi.

146 Chcielibyśmy przedstawić to zagadnienie na przykładach. W sprawie członka partii Joachima Syrzisko z Ciarki (powiat oleski) wystąpił aż urząd okręgowy w 1935 r. (APO, RO I, sygn. 13707, fol. 758, pismo z 15 stycznia 1935 r.; por. też F. Kasperek, Przymusowe sterylizacje w rejencji opolskiej 1934-1938, „Przegląd Lekarski” 1980, nr 1, s. 38. Podobny kazus dotyczył SA-mana T. Skrzypka z Olesna; APO, RO I, sygn. 13708, fol. 472 n.). Syrzisko został objęty postępowaniem sterylizacyjnym przed sądem pierwszej i drugiej instancji. Nie godząc się z rozstrzygnięciem i nie chcąc się poddać sterylizacji, za pośrednictwem urzędu okręgowego wniósł prośbę do Führera. $Z$ tego względu urząd okręgowy zwrócił się z prośbą do powiatowego radcy medycznego o powstrzymanie się od przymusowego przeprowadzenia sterylizacji aż do rozstrzygnięcia wniosku o ponowne pod- 
Koniec 1939 i początek 1940 roku był okresem, kiedy to zaczęto stopniowo zastępować sterylizację, rozpoczynając od Żydów, jeszcze bardziej złowieszczą eutanazją ${ }^{147}$. Ta hitlerowska praktyka eutanazji bezwzględnie negowała nie tylko fundamentalne naturalne prawo człowieka do życia i godności, lecz także prawa osobiste w rozumieniu cywilistycznym. W Polsce dokonywanie eutanazji chorych psychicznie i niedorozwiniętych umysłowo (Vernichtung von lebensunwertem Leben) rozpoczęło się już w pierwszych tygodniach okupacji hitlerowskiej ${ }^{148}$.

jęcie postępowania. Było to o tyle istotne, gdyż kancelaria partyjna przeniosła rozstrzygnięcie prośby do urzędu okręgowego we Wrocławiu. W tej sytuacji lekarz powiatowy poinformował o odwołaniu prezydenta rejencji opolskiej (APO, RO I, sygn. 13707, fol. 759 n.). W tej bardzo skomplikowanej sprawie Syrzisko kilkakrotnie odwoływał się do Reichsleitung. W jego obronie wystąpił też GAL. Podniósł on między innymi okoliczność, że Syrzisko nie jest dotknięty chorobą dziedziczną, lecz epilepsją, której nabawił się, spadając z drzewa podczas III powstania śląskiego (APO, RO I, sygn. 13707, fol. 781, 782). Reichsleitung, do którego zwrócił się Syrzisko nie rozpatrzyło sprawy, lecz przekazało ją do Ministra Spraw Wewnętrznych (APO, RO I, sygn. 13707, fol. 783-789). Rozpoczęte dochodzenie władz administracyjnych jednak nie potwierdziło twierdzeń Syrziska (APO, RO I, sygn. 13707, fol. 790-800). Ostateczna decyzja ministra potwierdziła natomiast decyzję sądów pierwszej i drugiej instancji. Zauważono, że twierdzenia podsądnego o nabyciu epilepsji nie zostały potwierdzone, i nakazano natychmiastowe wykonanie kastracji. W opisanym kazusie widać wyraźnie, że w omawianej sferze realizacji ustawy sterylizacyjnej urzędy ds. zdrowia narodowego nie uzyskały decydującego stanowiska, mogły jedynie wyrażać prośby i przedstawiać stanowisko. Decydowała wyłącznie administracja państwowa. Podany przykład wskazuje na paradoksalną sytuację, że władze państwowe były bardziej nazistowskie niż sama partia, która stanowiła władzom pewne kryteria postępowania w ustawie sterylizacyjnej. Kryteria te zostały sztywno skonstruowane i nawet sama NSDAP, chcąca uwolnić jednego ze swoich członków, natrafiła na sprzeciw biurokracji.

Inną interesującą sytuacją była sprawa sterylizacji członka partii Brunona Olschytzki z Jaźwiny (pow. dzierżoniowski) w 1941 r. (APWr., RB I, sygn. 8428, fol. 117 i n.) W jego sprawie stosowne pismo wysłał prezydent rejencji wrocławskiej do Ministra Spraw Wewnętrznych. Za Olschytzką wstawił się bowiem gauleiter Hanke (APWr., RB I, sygn. 8428, fol. 117 i 117v, pismo z 27 III 1941 r. Gauleiter stwierdził między innymi „Unfruchtbarmachung ist nicht erforderlich”). Jak podkreślono, „znał go osobiście, jest to dobry narodowy socjalista, regularnie uczestniczy w imprezach partyjnych”. W tej sytuacji kreisleitung w Dzierżoniowie poprosiło o szybkie przesłanie danych z sądu sterylizacyjnego w celu sprawdzenia wszelkich okoliczności sprawy. Sąd się nie spieszył, stąd też partia domagała się przesłania akt (APWr., RB I, sygn. 8428, fol. 118 i 119, ponowienie z 21 lipca 1941 r.) Ostatecznie wstawiennictwo gauleitera nie przyniosło rezultatu, gdyż z kancelarii partyjnej nadeszło pismo, w którym stwierdzono, że „nie ma żadnych wątpliwości” co do przeprowadzenia ubezpłodnienia (23 września 1941 r.); podobne pismo wystosował też Minister Spraw Wewnętrznych (APWr., RB I, sygn. 8428, fol. 122 i 123). Zwłaszcza ten drugi kazus jest znamienny, bo pod wpływem krytyki w 1937 r. tego środka dyskryminacji, jakim była sterylizacja, $i$ to nawet przez wysokich funkcjonariuszy reżimu, ograniczono korzystanie z ustawy, zwłaszcza w stosunku do członków NSDAP; F. Połomski, Rasizm w teorii i praktyce Trzeciej Rzeszy, s. 129.

147 Doktryna Lebensunwertes Leben, ,życia niewartego życia”, realizowana była, początkowo potajemnie już w pierwszych latach narodowosocjalistycznego reżimu w odniesieniu do niemowląt i dzieci dotkniętych wrodzonym kalectwem oraz wadami rozwojowymi.

148 Dyrektywa Hitlera z października 1939 r., antydatowana na 1 września 1939 r., oparta na ustaleniach dokonanych podczas narady 20 lub 21 września 1939 r. w Grand Hotelu w Sopocie z udziałem Hitlera, jego lekarza przybocznego dr. Karla Brandta, Philippa Bouhlera, dr. Leonardo Contiego i innych, czyniła Reichsleitera Bouhlera i dr. Brandta osobami odpowiedzialnymi za 
Program eutanazji $(E-\text { Aktion })^{149}$, który stał się elementem składowym Holokaustu, realizowano w latach 1939-1944 nie tylko w Altreichu, ale i na ziemiach wcielonych do Rzeszy oraz terytoriach okupowanych. Na ziemiach wcielonych dokonywano też eutanazji chorych psychicznie ${ }^{150}$. Najbardziej zbrodnicze z tych wydarzeń, które miały miejsce w prowincji śląskiej, rozegrały się w zakładzie w Lublińcu ${ }^{151}$.

Konkludując: w stosunku do ludności polskiej na ziemiach polskich wcielonych do Trzeciej Rzeszy stosowano kryteria narodowościowe i rasistowskie, ewidentnie naruszające zasadę równości podmiotów prawa prywatnego. Charakterystyczna dla prawa cywilnego XIX i XX wieku zasada równego dostępu do praw podmiotowych prywatnych była przestrzegana na polskich ziemiach wcielonych tylko w odniesieniu do ludności niemieckiej, i to tylko tej jej części, która biernie poddawała się indoktrynacji. W stosunku do Żydów rasizm przekreślał przy tym całkowicie ideę i koncepcję praw podmiotowych prywatnych.

\section{Bibliografia}

\section{Akty normatywne}

\section{Źródła archiwalne}

Archiwum Państwowe w Katowicach, Nadprezydium Prowincji Górnośląskiej, sygn. 2182 i 2183. Archiwum Państwowe we Wrocławiu, Rejencja wrocławska, sygn. 182, 1985-1987, 2017, 2037 2041, 2043, 2045, 2053, 8415, 8419-8438, 8458.

zapewnienie ludziom nieuleczalnie chorym wobec zupełnie krytycznej oceny stanu ich zdrowia „łaskawej śmierci” (Gnadentod); L. Górnicki, T. Kruszewski, op. cit., s. 66-67.

149 Określano go kryptonimem T 4 (od adresu placówki kierującej akcją zagłady, mieszczącej się w Berlinie przy Tiergartenstrasse 4).

${ }^{150}$ W stosunku do Górnego Śląska zob. ustalenia Ryszarda Kaczmarka, który dowodzi, że Górny Śląsk, tak jak całość terenów wcielonych, stał się miejscem realizacji ludobójczej polityki rasowej, której ofiarami padli przede wszystkim Żydzi, przy czym polityka ta, oparta na eugenice, prowadziła do eksterminacji także innych grup uznanych w nazistowskich Niemczech za zagrażające ,rasie aryjskiej”, w tym Romów, tak zwanych asocjalnych i chorych psychicznie; R. Kaczmarek, Górny Śląsk podczas II wojny światowej. Między utopią niemieckiej wspólnoty narodowej a rzeczywistościa okupacji na terenach wcielonych do Trzeciej Rzeszy, Katowice 2006, s. 215-237.

151 D. Moskwa, Eksterminacja w zakładzie „Loben”, „Przegląd Lekarski” 1975, nr 1, s. 112 114; K. Uzarczyk, Podstawy ideologiczne higieny ras i ich realizacja na przykładzie Ślaska w latach 1924-1944, Toruń 2002, s. 285 n. J. Mikulski, Akcja ,eutanazji” w stosunku do dzieci, [w:] Dzieci i młodzież w latach II wojny światowej, red. C. Pilichowski, Warszawa 1982, s. 396 n. Zbrodniarze ci uniknęli kary, choć śledztwo Instytut Pamięci Narodowej (w spadku po Komisji Badania Zbrodni Hitlerowskich w Polsce) ciągle prowadzi, ostatnio wznowiono je w 2000 r.; Senat RP IV kadencji, druk nr 773, Warszawa dnia 3 sierpnia 2001 r., pismo prezesa IPN prof. Leona Kieresa do marszałek Senatu prof. Alicji Grześkowiak, s. 52 i 53. Próba policzenia dzieci zob. K. Uzarczyk, op. cit. Tabela dzieci zamordowanych w zakładzie - s. 288. 
Wydział Samorządowy Prowincji Dolnośląskiej, sygn. 1773, 1987, 1996, 2000, 2001, 2003-2007, 2015, 2016, 2019.

Archiwum Państwowe w Opolu, Rejencja opolska, sygn. 13704, 13706, 13707, 13708.

\section{Źródła drukowane}

\section{Prawo niemieckie}

a) Reichsgesetzblatt (dalej RGBl. I)

RGB1., Jg. 1873, s. 61 - Reichsbeamtengesetz. Vom 31. März 1873.

RGBl. I, Jg. 1933, s. 83 - Verordnung des Reichspräsidenten zum Schutz von Volk und Staat. Vom 28. Februar 1933.

RGB1. I, Jg. 1933, s. 141 - Gesetz zur Behebung der Not von Volk und Reich. Vom 24. März 1933.

RGB1. I, Jg. 1933, s. 175 - Gesetz zur Wiederherstellung des Berufsbeamtentums. Vom 7. April 1933.

RGB1. I, Jg. 1933, s. 195 - Erste Verordnung zur Durchführung des Gesetzes zur Wiederherstellung des Berufsbeamtentums. Vom 11. April 1933.

RGB1. I, Jg. 1933, s. 222 - Verordnung über die Zulassung von Ärzten zur Tätigkeit bei den Krankenkassen. Vom 22. April 1933.

RGB1. I, Jg. 1933, s. 233 - Zweite Verordnung zur Durchführung des Gesetzes zur Wiederherstellung des Berufsbeamtentums. Vom 4. Mai 1933.

RGB1. I, Jg. 1933, s. 245 - Dritte Verordnung zur Durchführung des Gesetzes zur Wiederherstellung des Berufsbeamtentums. Vom 26. Mai 1933.

RGB1. I, Jg. 1933, s. 389 - Gesetz zur Änderung des Gesetzes zur Wiederherstellung des Berufsbeamtentums. Vom 23. Juli 1933.

RGB1. I, Jg. 1933, s. 433 - Gesetz zur Änderung von Vorschriften auf dem Gebiete des allgemeinen Beamten-, des Besoldungs- und des Versorgungsrechts. Vom 30. Juni 1933.

RGB1. I, Jg. 1933, s. 458 - Verordnung zur Ergänzung der Zweiten Verordnung zur Durchführung des Gesetzes zur Wiederherstellung des Berufsbeamtentums. Vom 7. Juli 1933. RGB1. I, Jg. 1933, s. 480 - Gesetz über den Widerruf von Einbürgerungen und die Aberkennung der deutschen Staatsangehörigkeit. Vom 14. Juli 1933.

RGB1. I, Jg. 1933, s. 515 — Vierte Verordnung zur Durchführung des Gesetzes zur Wiederherstellung des Berufsbeamtentums. Vom 18. Juli 1933.

RGBl. I, Jg. 1933, s. 518 - Gesetz zur Ergänzung des Gesetzes zur Wiederherstellung des Berufsbeamtentums. Vom 20. Juli 1933.

RGB1. I, Jg. 1933, s. 529 - Gesetz zur Verhütung erbkranken Nachwuchses. Vom 14. Juli 1933.

RGB1. I, Jg. 1933, s. 655 - Dritte Gesetz zur Änderung des Gesetzes zur Wiederherstellung des Berufsbeamtentums. Vom 22. September 1933.

RGB1. I, Jg. 1933, s. 678 - Zweite Verordnung zur Änderung und Ergänzung der Zweiten Verordnung zur Durchführung des Gesetzes zur Wiederherstellung des Berufsbeamtentums. Vom 28. September 1933.

RGBl. I, Jg. 1933, s. 685 - Reichserbhofgesetz. Vom 29. September 1933.

RGB1. I, Jg. 1933, s. 697 - Fünfte Verordnung zur Durchführung des Gesetzes zur Wiederherstellung des Berufsbeamtentums. Vom 29. September 1933).

RGBl. I, Jg. 1933, s. 749 - Erste Durchführungsverordnung zum Reichserbhofgesetze, insbesondere über Einrichtung und Verfahren der Anerbenbehörden. Vom 19. Oktober 1933, RGB1. I, Jg. 1933, s. 979 - Gesetz gegen Missbräuche bei Eheschließung und der Annahme an Kindes Staat. Vom 23. November 1933. 
RGB1. I, Jg. 1933, s. 1021 - Verordnung zur Verhütung erbkranken Nachwuchses. Vom 5. Dezember 1933.

RGB1. I, Jg. 1935, s. 192 - Verordnung über die Zulassung von Zahnärzten und Dentisten bei den Krankenkassen. Vom 13. Februar 1935.

RGB1. I, Jg. 1935, s. 289 - Dritte Verordnung zur Ausführung des Gesetzes zur Verhütung erbkranken Nachwuchses. Vom 25. Februar 1935.

RGB1. I, Jg. 1935, s. 593 - Gesetz zur Änderung des Reichs- und Staatsangehörigkeitsgesetzes. Vom 15. Mai 1935.

RGB1. I, Jg. 1935, s. 609 - Wehrgesetz. Vom 21. Mai 1935.

RGB1. I, Jg. 1935, s. 1146 - Reichsbürgergesetz. Vom 15. September 1935.

RGB1. I, Jg. 1935, s. 1146 - Gesetz zum Schutze des deutschen Blutes und der deutschen Ehre. Vom 15. September 1935.

RGB1. I, Jg. 1935, s. 1246 - Gesetz zum Schutze des Erbgesundheit des deutschen Volkes (Ehegesundheitsgesetz). Vom 18. Oktober 1935.

RGB1. I, Jg. 1935, s. 1333 - Erste Verordnung zum Reichsbürgergesetz. Vom 14. November 1935.

RGBl. I, Jg. 1935, s. 1334 - Erste Verordnung zur Ausführung des Gesetzes zum Schutze des deutschen Blutes und der deutschen Ehre. Vom 14. November 1935.

RGBl. I, Jg. 1935, s. 1419 - Erste Verordnung zur Durchführung des Ehegesundheitsgesetzes. Vom 29. November 1935.

RGBl. I, Jg. 1935, s. 1433 - Reichsärzteordnung. Vom 13. Dezember 1935.

RGB1. I, Jg. 1935, s. 1478 - Gesetz zur Verhütung von Missbräuchen auf dem Gebiete der Rechtsberatung. Vom 13. Dezember 1935.

RGB1. I, Jg. 1935, s. 1481 - Verordnung zur Ausführung des Gesetzes zur Verhütung von Missbräuchen auf dem Gebiete der Rechtsberatung. Vom 13. Dezember 1935.

RGB1. I, Jg. 1935, s. 1524 - Zweite Verordnung zum Reichsbürgergesetz. Vom 21. Dezember 1935.

RGB1. I, Jg. 1936, s. 11 - Verordnung zur Durchführung des $\S 107$ a der Reichsabgabeordnung. Vom 11. Januar 1936.

RGBl. I, Jg. 1936, s. 122 - Fünfte Verordnung zur Ausführung des Gesetzes zur Verhütung erbkranken Nachwuchses.

RGB1. I, Jg. 1936, s. 317 - Erste Verordnung zum Gesetz über die Verpachtung und Verwaltung öffentlicher Apotheken. Vom 26 März 1936.

RGBl. I, Jg. 1936, s. 347 - Reichstierärzteordnung. Vom 3. April 1936.

RGB1. I, Jg. 1936, s. 524 - Verordnung über die geschäftsmäßige Hilfeleistung in Devisensachen. Vom 29. Juni 1936.

RGB1. I, Jg. 1937, s. 39 n. - Deutsches Beamtengesetz. Vom 26. Januar 1937.

RGB1. I, Jg. 1937, s. 71 - Reichsdienststrafordnung (RDStO). Vom 26. Januar 1937.

RGB1. I, Jg. 1937, s. 191 - Reichsnotarenordnung. Vom 13. Februar 1937.

RGB1. I, Jg. 1937, s. 1118 - Bestellungsordnung für Apotheker. Vom 8. Oktober 1937.

RGB1. I, Jg. 1937, s. 1146 - Personenstandgesetz. Vom 3. November 1937.

RGBl. I, Jg. 1938, s. 9 - Gesetz über die Änderung von Familiennamen und Vornamen. Vom 5. Januar 1938.

RGB1. I, Jg. 1938, s. 807 - Gesetz zur Vereinheitlichung des Rechts der Eheschließung und der Ehescheidung im Lande Österreich und im übrigen Reichsgebiet. Vom 6. Juli 1938.

RGB1. I, Jg. 1938, s. 913 - Verordnung über Kennkarten. Vom 22. Juli 1938.

RGB1. I, Jg. 1938, s. 922 - Dritte Bekanntmachung über Kennkartenzwang. Vom 23. Juli 1938.

RGB1. I, Jg. 1938, s. 923 — Verordnung zur Durchführung und Ergänzung des zur Vereinheitlichung des Rechts der Eheschließung und der Ehescheidung im Lande Österreich und im übrigen Reichsgebiet (Ehegesetz). Vom 28. September 1938.

RGB1. I, Jg. 1938, s. 969 - Vierte Verordnung zum Reichsbürgergesetz. Vom 25. Juli 1938. 
RGB1. I, Jg. 1938, s. 1044 - Zweite Verordnung zur Durchführung des Gesetzes über die Änderung von Familiennamen und Vornamen. Vom 17. August 1938.

RGBl. I, Jg. 1938, s. 1323 - Zweite Verordnung zur Durchführung und Ergänzung des Ehegesetzes. Vom 27. Juli 1938.

RGB1. I, Jg. 1938, s. 1342 - Verordnung über Reisepässe von Juden. Vom 5. Oktober 1938. RGB1. I, Jg. 1938, s. 1391 - Verordnung über die Teilnahme von Juden an der kassenärztlichen Versorgung. Vom 6. Oktober 1938.

RGB1. I, Jg. 1938, s. 1403, Fünfte Verordnung zum Reichsbürgergesetz. Vom 27. September 1938.

RGB1. I, Jg. 1938, s. 1545 - Sechste Verordnung zum Reichsbürgergesetz. Vom 31. Oktober 1938.

RGBl. I, Jg. 1938, s. 1573 - Verordnung gegen den Waffenbesitz der Juden. Vom 11. November 1938.

RGB1. I, Jg. 1938, s. 1580 - Verordnung zur Ausschaltung der Juden aus dem deutschen Wirtschaftsleben. Vom 12. November 1938.

RGB1. I, Jg. 1938, s. 1649 — Verordnung über die öffentliche Fürsorge für Juden. Vom 19. November 1938.

RGB1. I, Jg. 1938, s. 1676 - Polizeiverordnung über das Auftreten der Juden in der Öffentlichkeit. Vom 28. November 1938.

RGB1. I, Jg. 1938, s. 1893 - Hebammengesetz. Vom 21. Dezember 1938,

RGBl. I, Jg. 1939, s. 47 - Achte Verordnung zum Reichsbürgergesetz. Vom 17. Januar 1939;

RGB1. I, Jg. 1939, s. 1098, Zehnte Verordnung zum Reichsbürgergesetz. Vom 4. Juli 1939

RGB1. I, Jg. 1939, s. 1567 - Verordnung zur Bestellungsordnung für Apotheker. Vom 1. September 1939.

RGBl. I, Jg. 1939, s. 2042, Erlass des Führers und Reichskanzlers über die Gliederung und Verwaltung der Ostgebiete. Vom 8. Oktober 1939.

RGB1 I, Jg. 1939, s. 2077, Erlaß des Führers und Reichskanzlers über die Verwaltung der besetzten polnischen Gebiete. Vom 12. Oktober 1939.

RGB1. I, Jg. 1939, s. 2096 - Dritte Durchführungsverordnung zum Gesetz über das Feuerlöschwesen (Organisation der Freiwilligen Feuerwehr). Vom 24. Oktober 1939.

RGB1. I, Jg. 1939, s. 2100 - Vierte Durchführungsverordnung zum Gesetz über das Feuerlöschwesen (Organisation der Pflichtfeuerwehr). Vom 24. Oktober 1939.

RGB1. I, Jg. 1939, s. 2239 - Erste Verordnung über berufsmäßige Ausübung der Säuglings- und Kinderpflege und die Errichtung von Säuglings- und Kinderpflegeschulen (Säuglings- und Kinderpflegeverordnung - SuKPflV-). Vom 15. November 1939.

RGB1. I, Jg. 1939, s. 2244 - Zweite Verordnung über berufsmäßige Ausübung der Säuglings- und Kinderpflege und die Errichtung von Säuglings- und Kinderpflegeschulen (Säuglings- und Kinderpflegeverordnung - SuKPflV-). Vom 15. November 1939.

RGB1. I, Jg. 1939, s. 2489 - Verordnung über die Einführung der reichsrechtlichen Vorschriften des Beamtenrechts und des Besoldungsrechts in den eingegliederten Ostgebieten. Vom 24. Dezember 1939.

RGB1. I, Jg. 1941, s. 118 - Verordnung über die Deutsche Volksliste und die deutsche Staatsangehörigkeit in den eingegliederten Ostgebieten. Vom 4. März 1941.

RGBl. I, Jg. 1941, s. 297 - Zweite Verordnung zur Ausführung des Gesetzes zum Schutze des deutschen Blutes und der deutschen Ehre. Vom 31. Mai 1941.

RGB1. I, Jg. 1941, s. 297, Verordnung über die Einführung der Nürnberger Rassengesetze in den eingegliederten Ostgebieten. Vom 31. Mai 1941.

RGB1. I, Jg. 1941, s. 372 - Verordnung über die Strafrechtspflege gegen Polen und Juden in den eingegliederten Ostgebieten. Vom 4. Dezember 1941.

RGB1. I, Jg. 1941, s. 547 - Polizeiverordnung über die Kennzeichnung der Juden. Vom 1. September 1941.

RGB1. I, Jg. 1941, s. 597, Veordnung über die bürgerliche Rechtspflege in den eingegliederten Ostgebieten (Ost-Rechtspflege-Verordnung-ORpfVO-). Vom. 25. September 1941. 
RGB1. I, Jg. 1941, s. 599, Erste Durchsführungsverordnung zur Verordnung über die bürgerliche Rechtspflege in den eingegliederten Ostgebieten (Ost-Rechtspflege-Verordnung-ORpflVO-). Vom. 25. September 1941.

RGB1. I, Jg. 1941, s. 650 - Zweite Durchsführungsverordnung zur Durchführung des Ehegesundheitsgesetzes. Vom 22. Oktober 1941.

RGB1. I, Jg. 1941, s. 675 - Verordnung über Beschäftigung von Juden. Vom 3. Oktober 1941.

RGB1. I, Jg. 1941, s. 681 - Verordnung zur Ausführung der Verordnung über Beschäftigung von Juden. Vom 31. Oktober 1941.

RGB1. I, Jg. 1941, s. 722 - Elfte Verordnung zum Reichsbürgergesetz. Vom 25. November 1941.

RGB1. I, Jg. 1942, s. 51 - Zweite Verordnung über die Deutsche Volksliste und die deutsche Staatsangehörigkeit in den eingegliederten Ostgebieten. Vom 31. Januar 1942.

RGB1. I, Jg. 1942, s. 120 — Erlass des Führers zur personalrechtlichen Vereinfachung. Vom 9. März 1942.

RGBl. I, Jg. 1943, s. 268 - Zwölfte Verordnung zum Reichsbürgergesetz. Vom 25. April 1943.

RGB1. I, Jg. 1943, s. 269 — Verordnung über die Staatsangehörigkeit auf Widerruf. Vom 25. April 1943.

RGBl. I, Jg. 1943, s. 271 — Erste Verordnung über die Schutzangehörigkeit des Deutschen Reichs. Vom 25. April 1943 (Verordnung über Schutzgehörigkeit).

RGBl. I, Jg. 1943, s. 315 - Erlass des Führers über den Erwerb der deutschen Staatsangehörigkeit durch Einstellung in die deutsche Wehrmacht, die Waffen-SS, die deutsche Polizei oder die Organisation Todt. Vom 19 Mai 1943.

RGB1. I, Jg. 1943, s. 372 — Dreizehnte Verordnung zum Reichsbürgergesetz. Vom 1. Juli 1943.

b) Deutsche Justiz

Deutsche Justiz, Jg. 1935, s. 1858, Nr. 364 Auswahl von Armenanwälten, Pflichtverteidigern, Konkursverwaltern und dergl., Allgemeineverfügung des Reichsjustizministers vom 19.12.1935, (IVb 8040).

Deutsche Justiz, Jg. 1942, s. 259, Nr. 151 Behandlung der in die Deutsche Volksliste eingetragener Personen, AV v. RJM v. 2. 4.1942 (1101 - Sdb - V. a 7 316).

c) Ministerialblatt für die Preußische innere Verwaltung

MBliV, Jg. 1934, szp. 118, Änderung von Familiennamen. RdErl. d. MdI. v. 17. 1. 1934 - I Z3/34.

MBliV, Jg. 1934, szp. 886, Änderung von Familiennamen und Vornamen, RdErl. d. MdI. v. 25. 6. $1934 \mathrm{IZ} 10 \mathrm{IV}$.

MBliV, Jg. 1934, szp. 886, Anlage. Richtlinien für die Bearbeitung der Anträge auf Änderung des Familiennamens.

MBliV, Jg. 1934, szp. 988, Vordrucke für Einbürgerungsurkunde, Heimatschein usw. RdErl. D. MdI. u. d. FM. v. 18. 7. 1934 - V Sta 4774 gen. u. I F 1075. 3-13. 7.

MBliV, Jg. 1935, szp. 1429, pkt f. Jg. 1935, Runderlass des Reichs- und Preussischen Minister den Innern. Vom 26. November 1935, I B 3/324 II.

MBliV, Jg. 1937, szp. 1605, RdErl. D. RuPrMdI. Vom 1. Oktober 1937, - IV A 12837/37/1079f.

MBliV, Jg. 1937, szp. 1700, Änderung von Familiennamen und Vornamen, RdErl. d. RuPrMdI. v. 10. 8. $1937-I B^{1} Z$ Allg. 21 II.

MBliV, Jg. 1938, szp. 1346, Vornamen. RdErl d. RMdI v. 18. 8. 1938 - I d 42 X/38-5501 b. MBliV, Jg. 1938, szp. 1722, Runderlass des Reichsinnenministers vom 17.10.1938 - V W II 1/388200, Berücksichtigung der Grundsätze der Rassengesetzgebung bei Bestellung von Einzelpersonen zu Vormündern, Pflegern, Helfern oder Beiständen. 
MBliV, Jg. 1939, szp. 350, Vornamen. RdErl d. RMdI v. 18. 2. 1939 - I d 113-5501 b. MBliV, Jg. 1939, szp. 1137 - Entjudung von Apothekenbetriebsrechten. RdErl. d. RMdI zgl. i. R. $d$. RWiM. V. 20. 5. 1939. - IV e 3612/39 - 4052.

MBliV, Jg. 1939, szp. 1291, Juden in Bädern und Kurorten. RdErl. D. RMdI zgl i. R. d. RMfBuP. v. 16. 6. 1939 - I e 16 XVII/39 - 5012e.

MBliV, Jg. 1939, szp. 1297, Durchführung der VO. über die öffentliche Fürsorge für Juden. RdErl. d. RAM. u. d. RMdI. v. 25. 5. 1939 - II b 2790/39 u. V W I 43/39-7808.

MBliV, Jg. 1939, szp. 1986, Ausf.- Anw. zu Art. II der 10. VO. zum Reichsbürgerges. v. 4. 7. 1939 (RGBl. I S. 1097). RdErl. D. RMfWEuV. zgl. i. R. d. RMdI. v. 14. 8. $1939-E$ I b 462 (b) u. I e $561 \mathrm{II} / 39-5012$.

MBliV, Jg. 1939, s. 2385 - Erwerb der deutschen Staatsangehörigkeit in den in das Deutsche Reich eingegliederten Ostgebieten. RdErl. D. RMdI. v. 25.11. 1939, - I e 5501/39 - 5000 Ost.

MBliV, Jg. 1940, s. 2111, Bescheinigungen über die Nichtzugehörigkeit zum polnischen Volke, RMdI Ie 5504 VIII-40 - 5000 Ost, RdErl. D. RMdI. Vom 14. November 1940.

MBliV, Jg. 1940, szp. 2261, Aufnahme jüdischer Geistekranker in Heil- und Pflegeanstalten. RdErl. d. RMdI. v. 12. 12. $1940-I V g$ 7123/40-5106.

MBliV, Jg. 1941, szp. 115 - Behandlung von Ausländer bei der Durchführung des Gesetzes zur Verhütung erbkranken Nachwuchses. RdErl. D. RMdI. V. 13. 1. 1941 - IV b 3611/40-1079 e.

MBliV, Jg. 1941, szp. 229 -, Erwerb der deutschen Staatsangehörigkeit durch ehemalige Danziger Staatsangehörige. RdErl. D. RMdI. v. 23. 12. 1941 - I Ost 1892/41 - 4160.

MBliV, Jg. 1941, szp. 927. Behandlung von Ausländer der Vordrucke zum Bericht über die Durchführung des Ges. zur Verhütung erbkranken Nachwuchses. RdErl. D. RMdI. V. 12. 5. 1941 -IV b 814/41 - 1079 .

MBliV, Jg. 1941, szp. 1645 - Einführung des Reichs- und Staatsangehörigkeitsges. v. 22. 7. 1913 in den eingegliederten Ostgebieten. RdErl. d. RMdI v. 11. 9. 1941 - I e 5350/41 Ost.

MBliV, Jg. 1941, szp. 2197. Durchf.-Best. zu § 10 der Elften VO. zum Reichsbürgerges. RdErl. d. RMdI. V. 12. 12. 1941 - II 6043/41 - 6100a.

MBliV, Jg. 1942, szp. 605, Durchführung des Ehegesundheitsgesetzes und des Gesetzes zur Verhütung erbkranken Nachwuchses gegenüber Juden. RdErl. D. RMdI. V. 19. 3. $1942-I V$ b 398/42-1075 a.

MBliV, Jg. 1942, szp. 997, Vereinfachung bei der Durchführung des Ges. zur Verhütung erbkranken Nachwuchses und des Ehegesundheitsges. RdErl. D. RMdI. V. 4. 5. 1942 - IV b 516/42 - 1079.

MBliV, Jg. 1942, szp. 1297, Durchführung des Art. 1 der Ersten VO. des Ges. zur Verhütung erbkranken Nachwuchses. RdErl. D. RMdI. V. 10. 6. 1942 - IV b 823 II/42 - 1079.

MBliV, Jg. 1942, szp. 1471, Vereinfachung der Verw.; hier: Verrechung bzw. Erstattung der für erbpflegerische Maßnahmen aufgewendeten Mittel. RdErl. D. RMdI. V. 10. 7. $1942-I V$ b 918-42 - 1079 - Mi.

MBliV, Jg. 1943, szp. 1627, Eheschließung von Beamten, RdErl. d. RMdI. v. 28. 9.1943 - III a 950 II/43 - 6101, auf Grund des Erlasses des Führers zur personalrechtlichen Vereinfachung v. 9. 3. 42 (RGBl. I, s. 120).

MBliV, Jg. 1944, szp. 54, Eheschließliesungen von Schutzangehörigen polnischer Volkstums. RdErl. d. RMdI. v. 10. 1. 1944 - I Sta R 5545 IV/43 - 4028.

d) Preussische Gesetzsammlung

Preussische Gesetzsammlung, s. 165, Bäuerlisches Erbhofrecht. Vom 15. Mai 1933.

e) Wydawnictwa źródłowe

Blau, B., Das Ausnahmerecht für die Juden in Deutschland 1933-1945, Düsseldorf 1965, Nr. 45, Prüfungsordnung für Ärzte und Zahnärzte. Vom 5. Februar 1934, Nr. 61. Reichshabilitationsord- 
nung. Vom 13. Dezember 1934, Nr. 339. Richtlinien für die Durchführung der Polizeiverordnung über die Kennzeichnung der Juden. Vom 10. Oktober 1941, Nr. 360. Anordnung der Aufsichtsbehörde über die Benutzung öffentlicher Fernsprechstelle durch Juden. Vom 26. Dezember 1941, Nr. 375, Bekanntmachung über die Kennzeichnung jüdischer Wohnungen. Vom 30. März 1942, Nr. 377. Anordnung über die Benutzung öffentlicher Verkehrsmittel. Vom 24. April 1942, Nr. 396. Anordnung über die Benutzung öffentlicher Verkehrsmittel. Vom 7. Juli 1942.

Konieczny A., Wybór tekstów źródtowych z historii państwa i prawa. Okres okupacji hitlerowskiej na ziemiach polskich, Wrocław 1977.

Pospieszalski K.M., Hitlerowskie „,prawo” okupacyjne w Polsce. Wybór dokumentów, cz. 1. Ziemie „wcielone”, Documenta Occupationis, t. 5, Poznań 1952:

Erlass für die Überprüfung und Aussonderung der Bevölkerung in den eingliederten Ostgebieten, Der Reichsführer SS Reichskommissar für die Festigung deutschen Volkstums I/K O 3b/28. 3. 40, Berlin 12. 9. 1940.

Der Reichsminister des Innern, Berlin, den 13. März 1941, 1 e 5125/41 5000 Ost, Erwerb der deutschen Staatsangehörigkeit durch ehemalige polnische und Danziger Staatsangehörige.

Rassische Musterung der Angehörigen der Abteilung 3 der Deutschen Volksliste, Anordnung 50/I. Vom 30. September 1941.

Allgemeine Anordnung Nr. 12/C über die Behandlung der in die Deutsche Volksliste eingetragener Personen. Vom 9. Februar 1942.

Zarządzenie Komisarza Rzeszy z 10 lutego 1942 r.

Zarządzenie Komisarza Rzeszy z 16 lutego 1942 r. (VII/41-176- II A 2 Nr. 420, Behandlung der in der Abteilung 4 der Deutschen Volksliste eingetragenen Personen).

Der Oberste Prüfungshof für Volkszugehörigkeitsfragen (Der Reichsminister des Innern, Berlin, den 30. Mai 1942, 1 Ost 768/42 4170, Verfahren und Zuständigkeit des Obersten Prüfungshofs für Volkszugehörigkeitsfragen in den eingliederten Ostgebieten.

Runderlass des Reichsministers des Innern betr. weitere Durchführungsvorschriften zur Verordnung über die Deutsche Volksliste; hier Eintragung verstorbener oder verschollener Personen. Vom 28. Juli 1943.

Reichssicherheitsamt IV D2-1218/41, Berlin den 12. Mai 1942, Betr. Deutschstämmige, die sich ihrer Wehrpflicht zu entziehen versuchen.

Oberkommando der Wehrmacht AZ.: 1 k 2036 AWA (BW Sied.)/AWA (J)/AHA/Ag./E/(Ia) Nr. 3358/42 Berlin, den 2. Oktober 1942, Betr. Behandlung der in Abt. 3 u. 4 der deutschen Volksliste eingetregenen Wehrpflichten und ihrer Angehörigen.

Der Oberste Prüfungshof für Volkszugehörigkeitsfragen z 3 stycznia 1944 r. w sprawie dokładniejszego określenia, kogo należałoby pozyskać dla zniemczenia.

Pospieszalski K.M., Hitlerowskie „prawo” okupacyjne w Polsce, cz. 2. Generalna Gubernia. Wybór dokumentów i próba syntezy, Documenta occupationis, t. 6, Poznań 1958:

Richtlinien zur Verordnung vom 29. Oktober 1941 über die Einführung eines Ausweises für Deutschstämmige im Generalgouvernement.

Der Reichsminister des Innern, Berlin den 18. März 1943, I Sta R 5147/43 5000 f, Betrifft: Einbürgerung von Inhabern der im Generalgouvernement ausgestellten Kennkarten für Volksdeutsche.

DerReichsministerdes Innern ISta 5428III/445000 GG, Berlin 10. November 1944, Betr. Rechtsstellungderausdem Generalgouvernementindas Reichumgesiedelten Deutschstämmigen.

Senat RP IV kadencji, druk nr 773, Warszawa dnia 3 sierpnia 2001 r., pismo prezesa IPN prof. Leona Kieresa do marszałek Senatu prof. Alicji Grześkowiak.

Ustawy norymberskie, http://www.kosciol.pl/article.php/20040914222342895?query=Ustawy+No rymberskie.

Wybrane dokumenty represji i życia codziennego. Cechy formalne i tto historyczne. Opracowane na podstawie zasobu Archiwum Fundacji „Polsko-Niemieckie Pojednanie”, Fundacja „Polsko-Niemieckie Pojednanie", Warszawa 2009. 


\section{Literatura}

Aly G., „Endlösung”. Völkerverschiebung und der Mord an den europäischen Juden, Frankfurt 1995.

Banaszkiewicz J., Powstanie partii hitlerowskiej. Studium socjologiczne genezy faszyzmu niemieckiego 1919-1923, Poznań 1968.

Barkai A., German Entrepreneurs and Jewish Policy in the Third Reich, „Yad Vashem Studies” $1991, \mathrm{nr} 21$.

Baumecker O., Nowe prądy w prawodawstwie państwa niemieckiego ze szczególnym uwzględnieniem ustawy o zagrodach dziedzicznych, Wydawnictwa Grup Polskich Porozumień Prawniczych z Zagranicą, z. 2. Grupa Prawnicza Polsko-Niemiecka, Warszawa 1938.

Berenstein T., Rutkowski A., Prześladowania ludności żydowskiej w okresie hitlerowskiej administracji wojskowej na okupowanych ziemiach polskich (1.IX.1939 r. - 25.X.1939 r.), „Biuletyn Żydowskiego Instytutu Historycznego" 1961, nr 18.

Berżyński M., Ustawa o obywatelstwie Rzeszy wobec mniejszości narodowych w Niemczech, „Sprawy Narodowościowe" 1935, nr 5.

Berżyński M., Ustawa o ochronie niemieckiej krwi i niemieckiej czci, „Sprawy Narodowościowe” $1935, \mathrm{nr} 5$.

Berżyński M., Ustawa o zagrodach dziedzicznych, „Sprawy Narodowościowe” 1934, nr 1.

Bock G., Zwangssterilisation im Nationalsozialismus. Studien zur Rassenpolitik und Frauenpolitik, Opladen 1986.

Broszat M., Der Staat Hitlers, München 1981.

Brzeski T., Ziemia i rasa w Trzeciej Rzeszy, „Przegląd Powszechny” 203, 1934, nr 607-608.

Büttner U., „Nichtarier” — „Judenmischlinge”- „Privilegierte Mischehen”: Die Verfolgung der christlich-jüdischen Familien im Dritten Reich, „Studia na Faszyzmem i Zbrodniami Hitlerowskimi" 14, 1991.

Bullock A., Hitler studium tyranii, cz. 3, Warszawa 1970.

Celnikier F., Pojęcie Żyda $w$ doktrynie $i$ hitlerowskim prawodawstwie, „Studia na Faszyzmem i Zbrodniami Hitlerowskimi” 9, 1985.

Cieślak T., Oranienburg-Sachsenhausen. Hitlerowskie obozy koncentracyjne w latach 1933-1945, Warszawa 1972.

Cyprian T., Sawicki J., Ludzie i sprawy Norymbergi, Poznań 1967.

Cyprian T., Sawicki J., Nieznana Norymberga. Dwanaście procesów norymberskich, Warszawa 1965.

Degenhart Ch., Das allgemeine Persönlichkeitsrecht, Art. 2 I i. Verbindung mit Art. 1 I GG, ,Juristische Schulung” 32, 1992, nr 1.

Dobosiewicz S., Mauthausen-Gusen obóz zagłady, Warszawa 1977.

Drolshagen E.D., Dzieci Wehrmachtu. W poszukiwaniu nieznanego ojca, Warszawa 2007.

Dunin-Wąsowicz K., Obóz koncentracyjny Stutthof, Gdynia 1966.

Dunvjak M., Veränderung des Rechts durch Gesetzgebung und Justiz im Nationalsozialismus, München 2005.

Ehrlich S., Ustrój i prawo ZSRR, Warszawa 1953.

Eisenbach A., Hitlerowska polityka zagłady Żydów, Warszawa 1961.

Erhardt H., Euthanasie und Vernichtung „, lebensunwerten” Lebens, „Forum der Psychiatrie” 1965 , nr 11.

Eksterminacja Żydów na ziemiach polskich w okresie okupacji hitlerowskiej. Zbiór dokumentów, oprac. T. Berenstein, A. Eisenbach, A. Rutkowski, Warszawa 1957. Entschädigung von NSUnrecht Regelungen zur Wiedergutmachung, Bundesministeriums der Finanzen, August 2011.

Eser A., Hirsch H.J., Sterilisation und Schwangerschaftsabbruch, Stuttgart 1980. 
Feder G., Der Deutsche Staat Auf Nationaler Und Sozialer Grundlage, München 1923.

Fest J., Oblicze Trzeciej Rzeszy, Warszawa 1970.

Fijałek J., Zagłada psychicznie i nieuleczalnie chorych dzieci oraz młodzieży w rejencji tódzkiej, [w:] idem, Zbrodnie hitlerowskie wobec dzieci i młodzieży Łodzi oraz okręgu tódzkiego, Łódź 1970.

Frank H., Rechtsgrundlegung des nationalsozialistischen Führerstaates, München 1938.

Gielo J., Gross Rosen, Warszawa 1970.

Gilbert M., Atlas historii Holocaustu, Liszki 2001.

Gilbert M., Holocaust. Ludzie. Dokumenty. Pamięć, Warszawa 2002.

Gottwald S., Zeitgeschichte und Dogmatik am Beispiel des allgemeinen Persönlichkeitsrechtes, „Forum Historiae Iuris” 7.08.1997, http://fhi.rg.mpg.de//articles/9708gottwald.htm.

Górnicki L., Kodyfikacja prawa prywatnego, [w:] System Prawa Prywatnego, t. 1. Prawo cywilne - część ogólna, red. M. Safjan, Warszawa 2012.

Górnicki L., Koncepcja prawa Trzeciej Rzeszy w poglądach prawników polskich (1933-1939), „Studia na Faszyzmem i Zbrodniami Hitlerowskimi” 16, 1993.

Górnicki L., Narodowosocjalistyczne prawo w pogladach Szymona Rundsteina, „Studia nad Faszyzmem i Zbrodniami Hitlerowskimi" (numer specjalny: Polskie interpretacje totalitaryzmu i autorytaryzmu) 33, 2011.

Górnicki L., O pojęciu i znaczeniu wielkich kodeksów cywilnych, „Kwartalnik Prawa Prywatnego” 2012, z. 1.

Górnicki L., Prawo Trzeciej Rzeszy w nauce i publicystyce prawniczej Polski międzywojennej (1933-1939), Bielsko-Biała 1993.

Grzybowski S.M., Pojęcie spadku i dziedzica w powszechnym prawie spadkowym a w niemieckiej ustawie o zagrodach dziedzicznych. Wykład habilitacyjny wygłoszony na posiedzeniu Rady Wydziału Prawa i Administracji UJ dnia 22 czerwca 1936, „Przegląd Sądowy” 1936, nr 10 i 11.

Gut A., Eutanazja - ukryte ludobójstwo pacjentów szpitali psychiatrycznych w Kraju Warty i na Pomorzu w latach 1939-1945, http://www.ipn.gov.pl/portal/pl/2/730/Eutanazja_8211_ukryte_ ludobojstwo_pacjentow_szpitali_psychiatrycznych_w_Kraju_Wa.html.

Halban L., Matżeństwo niemieckie. Podtug ustawy z 6 lipca 1938, Warszawa 1939 (odb.: „Przegląd Powszechny" 1939, nr 1 i 2).

Handbuch des Persönlichkeitsrechts, red. H-P. Götting, Ch. Schertz, W. Seitz, München 2008.

Hattenhauer H., Grundbegriffe des Bürgerlichen Rechts. Historisch-dogmatische Einführung, München 1982 ,

Hauberichs S., Haftung für neues Leben im deutschen und englischen Recht: eine Darstellung Am Beispiel der unerwünschten Geburt eines gesundes Kindes, Berlin-Heidelberg 1998.

Heydecker J., Leeb J., Trzecia Rzesza w świetle Norymbergii. Bilans tysiaca lat, Warszawa 1979.

Hilberg R., Sprawcy, ofiary, świadkowie. Zagłada Żydów 1933-1945, Warszawa 2007.

Hildebrandt, H., Rechtsfindung im neuen deutsche Staate, Berlin-Leipzig 1935.

Hitler A., Mein Kampf, München 1938.

Hojan A., Nazistowska pseudoeutanazja w Krajowym Zakładzie Psychiatrycznym w Kościanie, Kościan 2004.

Hrabar R., Hitlerowski rabunek dzieci polskich (1939-1945), Katowice 1960.

Hrabar R., ,Lebensborn” czyli źródło życia, Katowice 1976.

Jaworski S., Ustawa o zagrodach dziedzicznych a mniejszość polska w Niemczech, „Sprawy Narodowościowe" 1935, nr 3-4.

Jonca K., Koncepcje narodowosocjalistycznego prawa w Trzeciej Rzeszy, „Studia na Faszyzmem i Zbrodniami Hitlerowskimi” 3, 1977.

Jonca K., Naród polski w koncepcjach politycznych okupanta hitlerowskiego (1939-1945), [w:] Studia z dziejów myśli politycznej w Niemczech w XIX i XX wieku, red. H. Olszewski, Poznań 1982.

Jonca K., Polityka narodowościowa Trzeciej Rzeszy na Ślasku Opolskim (1933-1940). Studium polityczno-prawne, Katowice 1970. 
Joniec G., Antypolskie kampanie prasowe w sowieckiej prasie polskojęzycznej w latach 1939-1941, „Wschodni Rocznik Humanistyczny” 4, 2003.

Jütte R., Jüdische „Krankenbehandler”, [w:] Medizin und Nationalsozialismus. Bilanz und Perspektiven der Forschung, red. R. Jütte, Göttingen 2011.

Jütte R., Die Vertreibung jüdischer und ,, staatsfeindlicher” Ärztinnen und Ärzte, [w:] Medizin und Nationalsozialismus. Bilanz und Perspektiven der Forschung, red. R. Jütte, Göttingen 2011.

Kaczmarek R., Niemiecka polityka narodowościowa na Górnym Śląsku (1939-1945), „Pamięć i Sprawiedliwość" 2004, nr 2 (6).

Kaczmarek R., Polacy w Wehrmachcie, Kraków 2011.

Kasperek F., Przymusowe sterylizacje w rejencji opolskiej 1934-1938, „Przegląd Lekarski” 1980, $\mathrm{nr} 1$.

Kasperek F., Przymusowe sterylizacje w rejencji wrocławskiej 1934-1944, „Przegląd Lekarski” 1979, nr 1.

Kasperek F., Sterylizacja ze wskazań eugenicznych w latach 1934-1944 na Śląsku Opolskim, „Przegląd Lekarski" 1968, nr 1.

Kasznicki J., Zbrodnicze założenia medycyny hitlerowskiej, „Biuletyn Głównej Komisji Badania Zbrodni Hitlerowskich w Polsce" 29, 1979.

Kilian A., Przynależność państwowa do odwołania i jej konsekwencje jako element hitlerowskiej polityki asymilacyjnej, „Studia na Faszyzmem i Zbrodniami Hitlerowskimi” 11, 1987.

Klee E., Auschwitz. Medycyna III Rzeszy i jej ofiary, Kraków 2005.

Klee E., Dokumente zur »Euthanasie«, Frankfurt a.Main 1985 (ostatnie 5 wyd. 2001).

Klee E., »Euthanasie« im NS-Staat. Die Vernichtung »lebensunwerten Lebens«, Frankfurt a.Main 2004.

Klee E., Was sie taten - Was sie wurden. Ärzte, Juristen und andere Beiteligte an Kranken-oder Judenmord, Frankfurt a.Main 2004.

Kłodziński S., Z zagadnień ludobójstwa. Sterylizacja i kastracja promieniami Roentgena w obozie oświęcimskim. Dr Horst Schumann, „Przegląd Lekarski” 1964, nr 1.

Koellreutter O., Der Deutsche Führerstaat, Tübingen 1934.

Konieczny A., Rozwiąanie kwestii umysłowo chorych Żydów na Ślasku w latach 1938-1943, „Studia na Faszyzmem i Zbrodniami Hitlerowskimi” 18, 1995.

Korc E., Sołoma A., Z badań nad hitlerowska eutanazja w Prusach Wschodnich, „Studia na Faszyzmem i Zbrodniami Hitlerowskimi”" 12, 1987.

Koreng A., Das »Unternehmenspersönlichkeitsrecht» als Element des gewerblichen Reputationsschutzes, „Gewerblicher Rechtsschutz und Urheberrecht” 12, 2010.

Krajewski L., Doktryna prawna hitleryzmu, „Głos Sądownictwa” 1939, nr 1.

Krajewski L., Renesans monokracji, „Głos Sądownictwa” 1935, nr 7-8.

Kroeschell K., Die neue Eigentumslehre. Vorgeschichte und Nachwirkung, [w:] Rechtsgeschichte im Nationalsozialismus, red. M. Stolleis, D. Simon, Tübingen 1989.

Kruszewski T., Partia narodowosocjalistyczna na Śląsku w latach 1933-1945. Organizacja i dziatalność, Wrocław 1995.

Kuroński E., Położenie prawne ludności polskiej w Trzeciej Rzeszy, Katowice 1938.

L.(ichtszajn) L., Nowe kryteria prawa własności w Niemczech, GSW 1938, nr 8.

Larenz K., Rechts- und Staatsphilosophie der Gegenwart, Berlin 1935.

Larenz K., Rechtspersönlichkeit und subjektives Recht, [w:] Grundfragen der neuen Rechtswissenschaft, red. K. Larenz, Berlin 1935.

Larenz K., Über Gegenstand und Methode des völkischen Rechtsdenkens, Berlin 1938.

Look F., Die zivilrechtlichen Generalklauseln in der Rechtsprechung des Reichsgerichts 1933-1945, „Juristische Rundschau” 2000, nr 3.

Loose I., Credit Bank and The Holocaust in The Generalgouvernement 1939-1945, „Yad Vashem Studies" 2006, nr 34. 
Maciejewski M., Rozwój narodowosocjalistycznej ideologii w Niemczech po pierwszej wojnie światowej, „Studia na Faszyzmem i Zbrodniami Hitlerowskimi” 7, 1981.

Maciejewski M., Ruch i ideologia narodowych socjalistów w Republice Weimarskiej, Warszawa-Wrocław 1985.

Madajczyk C., Faszyzm i okupacje 1938-1945. Wykonywanie okupacji przez państwa Osi w Europie, t. 2. Mechanizmy realizowania okupacji, Poznań 1984.

Majer D., „Narodowo obcy” w III Rzeszy. Przyczynek do narodowo-socjalistycznego ustawodawstwa i praktyki prawniczej $w$ administracji i wymiarze sprawiedliwości ze szczególnym uwzględnieniem ziem wcielonych do Rzeszy i Generalnego Gubernatorstwa, Warszawa 1989.

Malczewski J., Życie niewarte przeżycia: eutanazja w stużbie utopii politycznej, „Czasopismo Prawno-Historyczne" 2009, z. 1.

Manigk A., Neubau des Privatrechts: Grundlagen und Bausteine, Leipzig 1938.

Manvell R., Fraenkel H., Himmler, Warszawa 1971.

Marrus M.R., Holocaust, Warszawa 1993.

Matzek T., Zamek śmierci Hartheim. Eutanazja w III Rzeszy, przeł. E. Borg, Warszawa 2004.

Miecik I.T., Okupacja — jak Trzecia Rzesza zaspokajała potrzeby seksualne żotnierzy Wehrmachtu w okupowanej Warszawie, „Newsweek Historia” 2011, nr 2, z. 3.

Mikulski J., Akcja ,eutanazji” w stosunku do dzieci, [w:] Dzieci i młodzież w latach II wojny światowej, red. C. Pilichowski, Warszawa 1982.

Moskwa D., Eksterminacja w zaktadzie „Loben”, „Przegląd Lekarski” 1975, nr 1.

Musielak M., Sterylizacja ludzi ze względów eugenicznych w Stanach Zjednoczonych, Niemczech $i$ w Polsce (1899-1945), Poznań 2008.

Musioł T., Dachau 1933-1945, Katowice 1968.

Mycielski A., Hitlerowska ustawa o zagrodach dziedzicznych na tle ogólnych założeń niemieckiego rasizmu, „Rocznik Prawniczy Wileński” 1939.

Nicolai H., Grundlagen der kommenden Verfassung: Über den staatsrechtlichen Aufbau des Dritten Reiches, Berlin 1933.

Nieludzka medycyna. Dokumenty procesu norymberskiego przeciwko lekarzom, oprac. A. Mitscherlich, F. Mielke, Warszawa 1965.

Okupacja sowiecka ziem polskich 1939-1941, Rzeszów 2005.

Olszewski H., Nauka historii w upadku. Studium o historiografii i ideologii historycznej w imperialistycznych Niemczech, Warszawa-Poznań 1982.

Olszewski H., Volk w ideologii nazizmu, [w:] Pojęcia Volk i Nation w historii Niemiec. Materiały z sesji naukowej zorganizowanej przez Zakład Historii Niemiec IH UAM w dniu 15.V.1979 r., red. A. Czubiński, Poznań 1980.

Olszewski M., Straty i martyrologia ludności polskiej w Poznaniu 1939-1945, Poznań 1973.

Parr K., Das Kindeswohl in 100 Jahren BGB. Inaugural-Dissertation zur Erlangung der Würde eines doctor iuris der Juristischen Fakultät der Bayerischen Julius-Maximilians-Universität Würzburg 2005.

Pawlita C., Geschichte der Entschädigung in der Bundesrepublik Deutschland, [w:] Zwangsarbeit im Nationalsozialismus und die Rolle der Justiz. Täterschaft, Nachkriegsprozesse und die Auseinandersetzung um Entschädigungsleistungen, red. H. Kramer, K. Uhl, J.-Ch, Wagner, Nordhausen 2007.

Pilichowski C., Badanie i ściganie zbrodni hitlerowskich 1944-1974, Warszawa 1975.

Pilichowski C., Plan i skutki polityki Trzeciej Rzeszy wobec Polski w okresie II wojny światowej, „Studia na Faszyzmem i Zbrodniami Hitlerowskimi” 3, 1977.

Pilichowski C., Zbrodnie i Sprawcy. Ludobójstwo hitlerowskie przed sądem ludzkości i historii, Warszawa 1980.

Pollaczek A., Pressefreiheit und Persönlichkeitsrecht, Saarbrücken 2007. 
Połomski F., Dobro ogólu przed dobrem jednostki. Hasło czy zasada prawna narodowych socjalistów, [w:] Historia - prawo - polityka. Profesorowi Franciszkowi Ryszce w sześćdziesiata piata rocznicę urodzin Przyjaciele, Koledzy, Uczniowie, Warszawa 1990.

Połomski F., Dyskryminacyjna funkcja „prawa rasowego” (Rassenrecht) Trzeciej Rzeszy (19331945), „Studia na Faszyzmem i Zbrodniami Hitlerowskimi” 1, 1974.

Połomski F., Nowe elementy prawa własności w hitlerowskiej ustawie o zagrodzie dziedzicznej (Reichserbhofgesetz) z 1933 roku, [w:] Parlament, prawo, ludzie. Studia ofiarowane profesorowi Juliuszowi Bardachowi w sześćdziesięciolecie pracy twórczej, red. K. Iwanicka, M. Skowronek, Warszawa 1996.

Połomski F., Ograniczenia w zawieraniu małżeństw Niemców z cudzoziemcami w czasie II wojny światowej, „Studia Śląskie” 32, 1977.

Połomski F., Państwo narodowosocjalistyczne a prawo własności, „Prawo” 137, 1986.

Połomski F., Prawo własności a tzw. „rozwiazanie kwestii żydowskiej” w Niemczech hitlerowskich, Wrocław 1991.

Połomski F., Rasistowskie przesłanki hitlerowskiej polityki „,zniemczania”, „Studia na Faszyzmem i Zbrodniami Hitlerowskimi” 7, 1981.

Połomski F., Rasizm w teorii i praktyce Trzeciej Rzeszy, „Studia na Faszyzmem i Zbrodniami Hitlerowskimi" 3, 1977.

Połomski F., Sąy do spraw sterylizacji w Trzeciej Rzeszy (1933-1945), „Studia Śląskie. Seria nowa" 20, 1971.

Połomski F., Spór o stosowanie hitlerowskiego ustawodawstwa sterylizacyjnego do Polaków na terenie Opolszczyzny, „Studia Śląskie. Seria nowa” 3, 1960.

Połomski F., Teoria ,krwi i ziemi”" (Blut und Boden), [w:] Studia z dziejów myśli politycznej w Niemczech XIX i XX wieku, Poznań 1982.

Połomski F., Ustawodawstwo rasistowskie III Rzeszy i jego stosowanie na Górnym Ślasku, Katowice 1970.

Połomski F., ,, Wrogowie Rzeszy Niemieckiej” jako kategoria polityczna i prawna, [w:] Studia nad antyhitlerowska opozycja w Trzeciej Rzeszy 1933-1945, red. K. Jonca, Warszawa 1990.

Pospieszalski K., Status prawny narodu polskiego na ziemiach zachodnich Rzeczypospolitej 19391945, [w:] Ekspertyzy i orzeczenia przed Najwyższym Trybunatem Narodowym, t. 2, red. C. Pilichowski, Warszawa 1979.

Poszukiwani świadkowie i informacja ze śledztwa w sprawie zamordowania $w$ latach 1939-1945 w tzw. zakładzie eutanazji w Hartheim koło Linzu (Republika Austrii) nieustalonej liczby obywateli polskich, http://www.ipn.gov.pl/portal.php?serwis=pl\&dzial=245\&id=3657\&search= 28932.

Püschel A., »...der Angeklagte ist Jude«. Die Auswirkungen der antisemitischen Gesetzgebung auf Bürger der Provinz Brandenburg 1933-1945 („Brandenburgische Historische” z. 2), wyd. 2, Potsdam 1998.

Radbruch G., Ustawowe bezprawie i ponadustawowe prawo, przeł. J. Stelmach, [w:] Zarys filozofii prawa, red. M. Szyszkowska, Białystok 2000.

Radzicki J., Radzicki J., Zbrodnie hitlerowskie na psychicznie chorych przed Amerykańskim Trybunatem Wojskowym w Norymberdze, Warszawa 1977.

Radzicki J., Radzicki J., Zbrodnie hitlerowskiej służby sanitarnej w Zakładzie dla Obłakanych w Obrzycach, Zielona Góra 1975.

Rawski C., Prawo o zagrodzie dziedzicznej, „Współczesna Myśl Prawnicza” 1936, nr 7.

Redzik A., Kotliński T.J., Historia adwokatury, Warszawa 2012.

Rickmann A.S., Rassenpflege im völkischen Staat: Vom Verhältnis der Rassenhygiene zur nationalsozialistischen Politik. Inaugural-Dissertation zur Erlangung der Doktorwürde der Philosophischen Fakultät. Der Rheinischen Friedrich-Wilhelms-Universität zu Bonn, Bonn 2002, http:// hss.ulb.uni-bonn.de/2002/0091/0091.pdf. 
Rüthers B., Entartetes Recht. Rechtslehren und Kronjuristen im Dritten Reich, München 1988.

Rüthers B., Die unbegrenzte Auslegung - Zum Wandel der Privatrechtsordnung im Nationalsozialismus, wyd. 5, Heidelberg 1997.

Rundstein S., W poszukiwaniu prawa cywilnego, Warszawa-Kraków 1939.

Rundstein S., Z badań nad teoria prawa (rec. pracy: Ogólna nauka o prawie, t. 2, Wilno 1938), cz. 2, „Gazeta Sądowa Warszawska” 1938, nr 12.

Ryszka F., Państwo stanu wyjątkowego. Rzecz o systemie państwa i prawa Trzeciej Rzeszy, Wrocław 1985.

Sadowski M., Scheffler T., Z badań nad nazistowska eutanazja we Wroctawiu, „Studia na Faszyzmem i Zbrodniami Hitlerowskimi” 19, 1996.

Salmonowicz S., Status prawny Polaka pod okupacja niemiecka (1939-1945). Uwagi o potrzebie badań, „Krakowskie Studia z Historii Państwa i Prawa” 9, 2016, nr 3.

Sas-Wisłocki J., Weryfikacja adwokatury w Niemczech, „Współczesna Myśl Prawnicza 1938, nr 12.

Schenk D., Albert Forster - gdański namiestnik Hitlera. Zbrodnie hitlerowskie w Gdańsku i Prusach Zachodnich, Gdańsk 2002.

Schlegelberger F., Abschied vom BGB, Berlin 1937.

Schmitt C., Über die drei Arten des rechtswissenschaftlichen Denkens, Hamburg 1934.

Schmitz-Köster D., "Deutsche Mutter, bist du bereit... «. Der Lebensborn und seiner Kinder, Berlin 2010 .

Schmitz-Köster D., Vankmann T., Lebenslang Lebensborn. Die Wunschkinder der SS und was aus ihnen wurde, München-Zürich 2012.

Schmul H.-W., »Euthanasie« und Krankenmord, [w:] Medizin und Nationalsozialismus. Bilanz und Perspektiven der Forschung, red. R. Jütte, Göttingen 2011.

Schmul, H.-W., Zwangssterilisation, [w:] Medizin und Nationalsozialismus. Bilanz und Perspektiven der Forschung, red. R. Jütte, Göttingen 2011.

Schubert W., Das Familien- und Erbrecht unter dem Nationalsozialismus. Ausgewählte Quellen zu den wichtigsten Gesetzen und Projekten aus den Ministerialakten, Paderborn 1993.

Siegmund A.M., »Das Geschlechtsleben bestimmen wir«. Sexualität im Dritten Reich, München 2009.

Sigmundt Ch., Rechtsgewinnung und Erbhofrecht. Eine Analyse der Methoden in Wissenschaft und Rechtsprechung des Reichserbhofrechts. Inaugural-Dissertation zur Erlangung der Würde eines doctor iuris der Juristischen Fakultät der Bayerischen Julius-Maximilians-Universität zu Würzburg, Würzburg 2005, http://opus.bibliothek.uniwuerzburg.de/volltexte/2005/1511/pdf/ Rechtsgewinnung_und_Erbhofrecht.pdf.

Sikora M., Zasady i praktyka przejęcia majątku polskiego przez III Rzeszę, ze szczególnym uwzględnieniem sektora rolnego oraz mieszkaniowego, na przykładzie prowincji ślaskiej (górnoślaskiej) w latach 1939-1944, „Pamięć i Sprawiedliwość” 2008, nr 2 (13); cz. 2 „Pamięć i Sprawiedliwość" 2009, nr 1 (14).

Sterkowicz, S., Nieludzka medycyna. Lekarze w stużbie nazizmu, Warszawa 2007.

Sterkowicz S., Zbrodnicze eksperymenty medyczne w obozach koncentracyjnych III Rzeszy, Warszawa 1981.

Stolleis M., Gemeinwohlformeln im nationalsozialistischen Recht (= Abhandlungen zur rechtswissenschaftlichen Grundlagenforschung 15), Berlin 1974.

Stutthof. Hitlerowski obóz koncentracyjny, Warszawa 1988.

Świrski I. ks. dr, Zagadnienie sterylizacji, Włocławek 1934.

Ternon Y., Helman S., Eksterminacja chorych psychicznie w III Rzeszy —od teoretyków narodowosocjalistycznych do praktyków z SS, Warszawa 1974.

Tołkaczew A., Prawo matżeńskie w narodowo-socjalistycznym ustawodawstwie niemieckim w latach 1933-1936, „Palestra” 1937, nr 5. 
Uzarczyk K., Podstawy ideologiczne higieny ras i ich realizacja na przykładzie Śląska w latach 1924-1944, Toruń 2002.

Vahle J., Das allgemeine Persönlichkeitsrecht - Eingriffsmerkmale und Schutzansprüche, „Neue Wirtschafts-Briefe" 2007, nr 5.

Volksgesetzbuch. Teilentwürfe, Arbeitsberichte und sonstige Materialien, red. W. Schubert, Berlin 1988.

Waligórski M., Działalność najeźdźcy hitlerowskiego $w$ dziedzinie jego funkcji ustawodawcy na terenie sadownictwa cywilnego, [w:] Ekspertyzy i orzeczenia przed Najwyższym Trybunatem Narodowym, t. 2, red. C. Pilichowski, Warszawa 1979.

Weiss S.F., Humangentik und Politik als wechselseitige Ressourcen. Das Kaiser-Wilhelm-Institut für Anthropologie, menschliche Erblehre und Eugenik im ,Dritten Reich'. Reihe: Ergebnisse, 17, im Programm: Geschichte der Kaiser-Wilhelm-Gesellschaft im Nationalsozialismus, http:// www.lbv.bwl.de/pdf/broschuere_entschaedigung_von_ns_unrecht.

Wieacker F., Privatrechtsgeschichte der Neuzeit unter besonderer Berücksichtigung der deutschen Entwicklung, Göttingen 1969.

Wittern F., Das Verhältnis von Right of Privacy und Persönlichkeitsrecht zur Freiheit der Massenmedien, Hamburg 2004, http://ediss.sub.uni-hamburg.de/volltexte/2004/2277/.

Zagłada chorych psychicznie w Polsce 1939-1945. Die Ermordung der Geisteskranken in Polen 1939-1945, red. Z. Jaroszewski, Warszawa 1993.

Zagłada psychicznie chorych, „Biuletyn Komisji Badania Zbrodni Niemieckich w Polsce” 3, 1947.

Zmierczak M., Jednostka a Volk w ideologii nazizmu, [w:] Studia z dziejów myśli politycznej w Niemczech w XIX i XX wieku, red. H. Olszewski, Poznań 1982.

Zmierczak M., Refleksje o prawie cywilnym w totalitarnym ustroju III Rzeszy, [w:] Ksiegga jubileuszowa Profesora Tadeusza Smyczyńskiego, Torun 2008.

Żuromski K., Ustawa Rzeszy Niemieckiej z 29.IX.1933 o dziedzicznych zagrodach chłopskich, „Przegląd Notarialny” 1934, nr 13-14. 